\title{
Los derechos sociales en los Estatutos de Autonomía*
}

\author{
Francisco López Menudo \\ Catedrático de Derecho Administrativo \\ Universidad de Sevilla
}

\begin{abstract}
SUMARIO: I. INTRODUCGIÓN.- II. LA LEGISLACIÓN AUTONÓMICA, FACTOR DE IMPULSO Y CONCRECIÓN DE LOS DERECHOS SOCIALES. UNA IMPRONTA SOBRE LA LABOR REALIZADA POR LAS COMUNIDADES AUTÓNOMAS EN ESTE ÁMBITO. 1. CONSIDERACIONES GENERALES. 2. OBJETO Y ESTRUCTURA DE LAS LEYES AUTONÓMICAS SOBRE LA MATERIA. 3. VALOR Y EFICACIA JURÍDICA DE LOS DERECHOS SOCIALES CREADOS POR LA LEGISLACIÓN AUTONÓMICA.- III. LA RECEPCIÓN DE LOS DERECHOS SOCIALES EN LOS ESTATUTOS DE AUTONOMÍA.- IV. UN EXCURSUS IMPUESTO POR LA STC 247/2007 DE 12 DE DICIEMBRE: PODER DE LA LEGISLACIÓN AUTONÓMICA PARA PROCLAMAR PRINCIPIOS, DERECHOS Y DEBERES. 1. LA POSIBILIDAD DE DESARROLLAR Y “ESPECIFICAR” DERECHOS FUNDAMENTALES. 2. LA POSIBILIDAD DE CREAR DERECHOS NUEVOS (O DERIVADOS DE PRINCIPIOS RECTORES CONSTITUCIONALES). 3. LÍMITES AL PODER NORMATIVO DE LOS PARLAMENTOS AUTONÓMICOS. A) Cobertura competencial suficiente. B) Respeto al ámbito de las leyes orgánicas reguladoras de los derechos fundamentales. C) Respeto al principio de igualdad ex art. 139. CE. D) El límite del artículo 138.2 CE. E) La sujeción al posible despliegue por el Estado de la potestad contenida en el artículo 149.1.1 ${ }^{a}$ CE.- V. LA POLÉMICA SOBRE LA LICITUD DE LA INCLUSIÓN DE PRINCIPIOS, DERECHOS Y DEBERES EN LOS ESTATUTOS DE AUTONOMÍA. 1. SOBRE LA OPORTUNIDAD DE SU INCLUSIÓN EN LOS ESTATUTOS. 2. SOBRE LA CONSTITUCIONALIDAD DE LA INSERCIÓN EN LOS ESTATUTOS DE DICHAS TABLAS DE PRINCIPIOS, DERECHOS Y DEBERES. A) El presunto impedimento formal: el tenor literal del artículo 147.2 CE. Posturas que se mantienen sobre el contenido posible de los Estatutos. a) Interpretaciones estrictas sobre el alcance del artículo 147.2 CE. b) Interpretaciones amplias so-
\end{abstract}

\footnotetext{
* Es reproducción literal del texto de la Ponencia elaborada para el IV Congreso de la Asociación Española de Profesores de Derecho Administrativo celebrado en Valladolid los días 6 y 7 de febrero de 2009 y que figura en el libro de Actas y Ponencias de dicho Congreso. Publicado por la Editorial Lex Nova, Valladolid, 2009. Trabajo elaborado en el marco del Plan andaluz de Investigación, Desarrollo e Innovación (PAIDI), Grupo de investigación SEJ-193. Junta de Andalucía.
} 


\begin{abstract}
bre el contenido estatutario posible. B) Los argumentos de fondo, a favor y en contra, sobre los enunciados de principios, derechos y deberes de los Estatutos de Autonomía. a) Primera cuestión. Sobre la relación entre los derechos fundamentales y las Cartas estatutarias de derechos. b) Sobre la petrificación y sustracción al juego democrático que puede suponer la inclusión de derechos en los Estatutos. c) Otra línea argumental. Los Estatutos son aprobados por leyes orgánicas del Estado. ¿Pueden éstas crear desigualdades entre los españoles? d) De nuevo sobre la sujeción a la potestad del Estado insita en el artículo 149.1.1 ${ }^{a}$ CE. e) El argumento del derecho comparado. f) La tesis de la STC 247/2007: los derechos sustantivos ex novo que proclaman los Estatutos no son derechos, sino mandatos a los poderes públicos autonómicos.- VI. LA EFICACIA DE LOS ENUNCIADOS ESTATUTARIOS. 1. Los enunciados estatutarios puramente retóricos. 2. El valor de los principios rectores estatutarios. 3. El valor de los derechos sustantivos proclamados en los Estatutos de Autonomía. 4. La vinculación entre las tablas estatutarias de principios y derechos y la legislación de desarrollo.
\end{abstract}

\title{
RESUMEN
}

Una de las novedades más destacadas que ofrecen los nuevos Estatutos de Autonomía surgidos del proceso de reforma habido en el bienio 2006-2007, ha sido la incorporación de una "parte dogmática" en la que se incluyen no sólo principios rectores de la política social y económica sino el reconocimiento de auténticos derechos para cuya protección se prevén expresamente en algunos Estatutos las vías procesales oportunas. Sin embargo, la Sentencia del Tribunal Constitucional 247/2007 de 12 de diciembre, relativa al impugnado Estatuto de la Comunidad Valenciana ha declarado con efectos generales que la mayoría de los enunciados estatutarios que se formulan como derechos subjetivos no tienen eficacia directa y precisan de la interpositio legislatoris, lo cual plantea la grave cuestión sobre cual sea el valor normativo de un Estatuto y si el Tribunal seguirá esa misma doctrina en futuras sentencias que ha de dictar en asuntos análogos.

Palabras clave:

Estatutos de Autonomía; Cartas de derechos sociales; derechos sociales; principios rectores de la política social y económica; derechos públicos subjetivos; desarrollo y especificación de derechos fundamentales.

\section{ABSTRACT}

One of the highlight innovations from the new Federals Constitutions (Estatutos de Autonomía) who emerged from reform process in 2006-2007, 
has been the incorporation of political rules in economic and social policy and the incorporation as well of declarations of human rights -most of them with a social and economic nature-, which the procedural protection is also provided. However, the Constitutional Court judgement of december 12 about the contested Estatuto of Valencia has stated that the federals declarations formulated as individual rights have no direct effect, because requires a law interposition (interpositio legislatoris). That raises a serious issue of the true "constitutional" and regulatory nature of news Estatutos.

Key Works:

Federal Constitution; Human Rights protection; constitutional jurisdiction.

\section{INTRODUCGIÓN}

Es difícil no estar de acuerdo en que siempre habría motivos poderosos para traer a primer plano cuestiones relativas a cualquiera de esos dos universos jurídicos cuales son los derechos sociales y los Estatutos de Autonomía. Sin duda que el interés aumenta, diríamos que se agiganta, si como en esta ocasión hay que hablar conjuntamente de ambos, o mejor dicho, de los problemas que genera su conjunción, la zona en la que se solapan. Ciertamente, no han de tratarse aquí los aspectos sustantivos de los numerosos sectores de la acción social (salud, dependencia, drogadicción, vivienda, menores, etc.), de los cuales existe literatura especializada muy copiosa, ni tampoco cabe recrearse en la figura misma del Estatuto de Autonomía si no es en aquellos precisos aspectos que deben ser considerados por razón de hecho nuevo y tan notable como es la inserción de tablas de principios y derechos en los Estatutos de la última hornada ${ }^{1}$.

Los derechos sociales de nuestro tiempo son el fruto de un largo devenir lleno de vicisitudes y de "crisis" que no han impedido su progresivo desarro-

\footnotetext{
${ }^{1}$ Leyes Orgánicas 1/2006 de 10 de abril, Estatuto Comunidad Valenciana; 6/2006 de 19 julio, Cataluña; 1/2007 de 28 febrero, Islas Baleares; 2/2007 de 19 marzo, Andalucía; 5/2007 de 20 abril, Aragón; 14/2007 de 30 noviembre, Castilla y León. Propuesta de Estatuto de Autonomía de Castilla-La Mancha actualmente en el Congreso de los Diputados pendiente de aprobación. La propuesta de Estatuto de Canarias fue presentada en el Congreso en septiembre de 2006 y retirada en diciembre de 2007 a petición del Parlamento canario (BOCD de 15 enero de 2008.
} 
llo. Aun con la carga a cuestas de esa crónica debilidad que se les viene atribuyendo desde siempre, han logrado plantarse en nuestro presente con un vigor que no han tenido nunca. El último episodio de ese devenir ha sido su inclusión en el pórtico mismo de los nuevos Estatutos, formando con ellos una simbiosis donde la ganancia recíproca es clara: los derechos sociales cobran renombre y fortaleza y los Estatutos ganan peso dogmático y un porte benefactor idóneo para justificar el propio hecho de su reforma y concitar adhesiones. Este súbito aterrizaje de los derechos sociales en los Estatutos es un suceso importante, tanto por su novedad como por su carácter masivo y sistemático; y es de toda lógica que el fenómeno haya hecho temblar el edificio de nuestro sistema autonómico y obligue a pasar revista, tras esa especie de seísmo, del estado de las piezas principales de su estructura.

Con lo dicho va de suyo que no nos encontramos ante un tema menor, por lo que no hay lugar para pararse a considerar aspectos de los derechos sociales que aunque sumamente atractivos para el jurista no forman parte esencial de lo que aquí nos ocupa. Concretamente, no cabe detenerse a recordar el origen y la evolución de los derechos sociales, o su concepto y fundamento, sus analogías y diferencias con las libertades y los derechos civiles y políticos, su proyección en el derecho internacional y comunitario, ni otros trascendentes aspectos, profusamente estudiados desde la filosofía, la ciencia política, el constitucionalismo, la economía y demás ciencias sociales. Figuras señeras de nuestro Derecho y autores de obras muy meritorias se han encargado de exponer las claves de fondo que enmarcan el tema de los derechos sociales o del Estado Social de Derecho². Plasmar aquí algunas de esas grandes cuestiones por vía de síntesis sería demasiado insignificante además de impropio para una ocasión como la presente.

\footnotetext{
${ }^{2}$ Aun a riesgo de incurrir en alguna omisión dado el vasto panorama considerado son de citar GARCÍA DE ENTERRÍA, E., "El reconocimiento de los derechos sociales en la Comunidad Europea" en Las estructuras del bienestar en Europa (dir. Muñoz Machado, García Delgado y González Seara), Civitas-Escuela Libre Editorial, Madrid, 2000, págs. 413 y ss. GARCÍA-PELAYO, M., Las transformaciones del Estado contemporáneo, Alianza Universidad, Madrid, 1977. PAREJO ALFONSO, L., Estado Social y Administración Pública. Los postulados constitucionales de la reforma administrativa, Civitas, Madrid, 1983. MUÑOZ MACHADO, S., Las estructuras del bienestar. Derecho, economía y sociedad en España (codirec. con García Delgado y González Seara), Civitas-Escuela Libre Editorial, Madrid, 1997; Las estructuras del bienestar. Propuestas de reforma y nuevos horizontes (codirec. con García Delgado y González Seara), Civitas-Escuela Libre Editorial, Madrid, 2002).; y en dicha obra "La contribución de las organizaciones sociales a la transformación del Estado de Bienestar", págs. 709 a 789; "La crisis del Estado del Bienestar y la cuestión de la reversibilidad de los derechos sociales: el caso de los minusválidos” en La integración social de los minusválidos: balance después de diez
} 
Por todo lo que precede no cabe dudar sobre el acierto en la elección del presente tema, lo que al no ser mérito propio podemos realzar sin pudor. Pero a ello hay que añadir la circunstancia afortunada de que estas reflexiones nacen en una coyuntura especial, en un momento de expectación irrepetible, en el interregno que media entre los ecos de las Sentencias del Tribunal Constitucional sobre el Estatuto valenciano ${ }^{3}$ y las vísperas mismas de la Sentencia que ha de recaer sobre el Estatuto de Cataluña, una norma singularmente potente en materia de principios y derechos de carácter social y, por tanto, un gran banco de pruebas para que el Tribunal se pronuncie definitivamente $-\mathrm{y}$ es de esperar que con argumentos suficientes- sobre lo que habiendo ya resuelto en las Sentencias citadas quizás no ha dejado satisfechos ni a tirios ni a troyanos, bien por la forma o por el fondo, o por ambas cosas a la vez. La Sentencia que próximamente ha de dictarse puede marcar un hito muy pronun-

años de vigencia de la Ley, Madrid, 1993, págs. 13-33. GARRORENA MORALES, A., El Estado espanol como Estado social y democrático de Derecho, Tecnos, Madrid, 1984. PECES-BARBA MARTíNEZ, G., Curso de Derechos Fundamentales. Teoría General, Universidad Carlos III de Madrid-Boletín Oficial del Estado, Madrid, 1999. PÉREZ LUÑO, A. E., "Los derechos sociales y su "status" normativo en la Constitución Española", Documentación Administrativa, núm. 271-272, INAP, 2005, págs. 13-38. "La positividad de los derechos sociales: su enfoque desde la Filosofía del Derecho". Derechos y libertades: Revista del Instituto Bartolomé de las Casas, año 10, 14, 2006, págs. 151-178. La tercera generación de derechos humanos, Aranzadi, 2006. Derechos humanos, Estado de Derecho y Constitución, Tecnos, 2005. DE CASTRO CID, B., Los derechos económicos sociales y culturales. Análisis a la luz de la teoría general de los derechos humanos. Universidad de León, León, 1993. ABRAMOVICH, V. y CURTIS, Ch., Los derechos sociales como derechos exigibles, Trotta, Madrid, 2002. BERRAONDO LÓPEZ, M. Los derechos humanos en la globalización, Diputación Foral de Guipúzcoa, Bilbao, 2004. CARRETERO SÁNCHEZ, S., El cambio de los derechos sociales y su justiciabilidad (Impacto jurídico de la inmigración en la teoría tradicional de los derechos humanos), Universidad Complutense Facultad de Derecho, Madrid, 2004. COSSÍO DÍAZ, J. R., Estado social y derechos de prestación, Centro de Estudios Constitucionales, Madrid, 1989. GARCÉS SANAGUSTÍN, A., Prestaciones sociales, función administrativa y derechos de los ciudadanos. McGraw Hill, Madrid, 1996. GARCÍA MORALES, A. F., La justiciabilidad de los derechos económicos, sociales y culturales, Universidad Complutense, Facultad de Derecho, Madrid, 2003. GONZÁLEZ MORENO, B., El Estado Social. Naturaleza jurídica y estructura de los derechos sociales, Universidad de Vigo-Civitas, Madrid, 2002. JIMENA QUESADA, L., Sistema europeo de derechos fundamentales, Colex, 2006. MONEREO ATIENZA, C., Ideologías jurídicas y cuestión social. Los orígenes de los derechos sociales en España,Comares, Granada, 2007. ORDÓÑEZ SOLÍS, D., La protección judicial de los derechos fundamentales de solidaridad, Comares, Granada, 2006. PISARELLO, G., Los derechos sociales y sus garantías. Elementos para una reconstrucción, Trotta, Madrid, 2007. RODRÍGUEZ OLVERA, O., Teoría de los derechos sociales en la Constitución abierta, Comares, Granada, 1998. VICENTE GIMÉNEZ, T., La exigibilidad de los derechos sociales, Tirant lo Blanch, Valencia, 2006.

${ }^{3}$ SSTC 247 y $249 / 2007$ de 12 y 13 de diciembre, respectivamente. 
ciado en la evolución de nuestros Estatutos de Autonomía si el Tribunal mantiene su doctrina de que los derechos estatutarios sustantivos no son realmente derechos, pues si tal ocurre es indudable que los futuros Estatutos adoptarán una configuración distinta a la de los seis que ya han sido aprobados ${ }^{4}$. He aquí, pues, un primer contraste o paradoja a tener en cuenta. Pero en general, el tema está atravesado de arriba abajo por otros contrastes, algunos de los cuales resaltaremos ahora, siquiera sea brevemente, en pro del mejor entendimiento de las páginas que siguen.

Lo primero a tener en cuenta es que los llamados derechos sociales, tradicionalmente no han sido nunca "derechos" en la acepción subjetiva del concepto, es decir, como algo exigible judicialmente por alguien. Por tanto, de entrada, es obligado convenir en que la expresión "derecho social" tiene más que ver con el derecho objetivo, con la idea de institución jurídica, con la de deberes que la ley impone a los poderes públicos o incluso con lo que pudiéramos llamar "derecho-aspiración", es decir, no el derecho actual a una cosa sino el derecho a poder desear y llegar a poseer, porque la ley lo considera justo y por ello ampara esa aspiración. Han vivido así los derechos sociales, con un traje más lustroso que su propio contenido; y en estas convenciones se ha movido la tradición jurídica en esta materia, pues la inmensa mayoría de los autores no renuncian al término "derecho" sino que lo remarcan como un acto de afirmación o de fe, reivindicativo siempre, a la par que exprimen del concepto "derecho" todas sus virtualidades posibles, aunque falto de la garantía jurisdiccional. Pero aun siendo cierto lo dicho, hay que tener muy en cuenta que algunos derechos sociales han venido siendo formulados como derechos subjetivos e incluso como derechos fundamentales (p. ej. derecho a la educación, derecho de huelga) y que en los últimos años la legislación ha configurado muy diversos beneficios o prestaciones sociales como auténticos derechos públicos subjetivos. Por ello, en la actualidad es necesario tener siempre presente esta dicotomía cuando hablamos de derechos sociales.

La anterior reflexión se conecta a otra paradoja. El panorama doctrinal está henchido de publicaciones cuyo común denominador es una especie de

\footnotetext{
${ }^{4}$ Digno de considerar será el caso del Estatuto de Castilla-La Mancha, que se halla actualmente en el Congreso y cuya aprobación es presumible que sea coetánea o posterior a la Sentencia que se dicte sobre el Estatuto catalán. Dicho texto estatutario sólo contiene derechos, no principios. ¿Cómo será posible aprobar un Estatuto que califica sus contenidos como derechos tras haber negado el TC esta posibilidad? Debe tenerse en cuenta que los seis Estatutos ya aprobados lo fueron con anterioridad a la STC $247 / 2007$.
} 
lamento porque los derechos sociales contemplados en la Constitución se encuentren separados de los derechos fundamentales y sean objeto de un distinto tratamiento, lo que muchos estiman artificioso e injustificado desde distintos puntos de vista. En numerosos casos, el análisis de la cuestión aparece como anclado en el examen de las limitaciones que la materia social encuentra en el artículo 53.3 CE, como si los principios rectores de su Cap. III, Tít. I, se hallaran aún in fieri, sin ejecución, o sea, tal como fueron estrenados hace 30 años; y es ocioso decir que ninguna valoración rigurosa sobre el peso real de los derechos sociales en el ordenamiento jurídico puede hacerse hoy sin tener en cuenta cómo los trata el derecho positivo que puebla los diarios oficiales. Muchísimas disposiciones muestran que no pocos principios han sido transformados en derechos y que por tanto no hay razones para adoptar posturas fatalistas y ensimismarse en lo que dice la letra de dicho Capítulo de la Constitución, ni de lamentarse por un estado de indefensión ante la Jurisdicción que en gran medida no es real en la actualidad. En lo que hay que poner el esfuerzo es en agudizar el ingenio y los argumentos con miras a conservar lo conseguido y buscar salidas positivas, criterios operativos, reglas ajustadas a Derecho, para hacer frente a momentos de crisis como los actuales, en los que pueden darse tentaciones de hacer tabla rasa de ciertas conquistas desde la antigua creencia de que ello es hacedero sin gran dificultad y además lógico en circunstancias económicas adversas ${ }^{5}$, tendencias éstas que deben ser debidamente controladas. Si como tantas veces se ha dicho el Estado de Derecho, para ser democrático, ha de ser social, también hay que decir que el Estado Social también debe serlo de Derecho.

Pero el contraste más llamativo es el que deriva del auge de los derechos sociales en los últimos años y el sonoro frenazo -no puede hablarse de caída, al menos aún- producido en tiempos bien recientes. Los factores de impulso han sido la bonanza económica, con la correlativa asunción de cargas financieras y riesgos por parte de los poderes públicos, el desempleo y la inmigración como factores de presión a la vez que de concienciación de las políticas públicas a adoptar, el movimiento favorable hacia los derechos sociales habido en la Unión Europea, primero mediante la Carta Europea de Derechos Fundamentales del año $2000^{6}$, y luego, redobladamente, por el Tratado de Constitu-

\footnotetext{
${ }^{5}$ Son ilustrativas al respecto las reflexiones de FERRAJOLI, Luigi, en el Prólogo al libro de ABRAMOVICH, V. y COURTIS, Ch., Los derechos sociales como derechos exigibles, cit.

${ }^{6}$ Es abundantísima la literatura al respecto. Entre otros, CORRIENTE CÓRDOBA, J. A., "La protección de los derechos económicos, sociales y culturales en la Carta de Derechos Fundamen-
} 
ción europea de $2004^{7}$, textos que han levantado un verdadero revuelo en la doctrina, dividida ésta entre la más pura euforia por la nueva "Europa de los derechos sociales" y un cierto escepticismo, visto el alcance discreto que dichos Instrumentos otorgan en realidad a tales "derechos". Si a todo ello se suma la incesante producción normativa sobre la materia habida en España, tanto por el Estado como por las Comunidades Autónomas, y los vientos favorables procedentes de Italia con la apertura de los nuevos Estatutos regionales a las tablas de principios y derechos en materia social, se entiende perfectamente que la coronación de este ascenso esté representada por los nuevos Estatutos de Autonomía. Éstos superan con creces en este punto los requerimientos más exigentes contenidos en Declaraciones, Tratados y Convenios internacionales, ello con independencia de que el movimiento reformador tenga otras causas o esté precisado de una mayor reflexión ${ }^{8}$. En fin, venimos de una etapa feliz para los derechos sociales, cuajada de factores que han coadyuvado a generar un estado de euforia de los poderes públicos sobre la posibilidad de reconocer y garantizar prestaciones de todo tipo al más alto nivel de garantías y seguridad.

tales de la Unión Europea”, Anuario de Derecho europeo, núm. 2, Universidad de Sevilla, 2002, págs. 117-135. FERNÁNDEZ TOMÁS, A., "La Carta de Derechos Fundamentales de la Unión Europea: estructura, ámbito de aplicación, invocabilidad y contenido" en Anuario de Derecho europeo, núm. 2, Universidad de Sevilla, 2002. CARRILlO LÓPEZ, M., "La Carta de Derechos Fundamentales de la Unión Europea”, Revista Vasca de Administración Pública, núm. 65, 2003, págs. 145-165. ESPADA RAMOS, M. L., "Los derechos sociales de la Unión Europea: mercado o justicia" en Anales de la Cátedra Francisco Suárez, núm. 35, 2001, págs. 23-57. GARCÍA GARCÍA, R., "La efectividad de los derechos sociales en el nuevo contexto europeo" en Revista Vasca de Administración Pública, núm. 65, 2003, págs. 51 y ss. GIL Y GIL, J. L. y USHAKOVA, T., "Los derechos sociales en la Carta de los Derechos Fundamentales de la Unión Europea" en Relaciones Laborales, núm. 1, 2003, págs. 1319-1344. LÓPEZ GUERRA, L., "Hacia un concepto europeo de Derechos Fundamentales" en Revista Vasca de Administración Pública, núm. 65, II, 2003, págs. 191 y ss. RODRÍGUEZ PIÑERO Y BRAVO FERRER, M., "Derechos sociales fundamentales y Unión Europea" en Relaciones Laborales, núm. 2, 2007, págs. 55 a 67. SCIARRA, S., "Derechos sociales. Reflexiones sobre la Carta europea de Derechos Fundamentales" en Temas Laborales, núm. 62, 2001, págs. 9 a 30. VV. AA., La Carta de Derechos Fundamentales de la Unión Europea:Una perspectiva pluridisciplinar, Fundación Rei Afonso Henriques, Valladolid, 2003.

${ }^{7}$ Entre otros, vid. MALARET, E. y MARSAL, M., "Constitución europea y derechos sociales" en Documentación Administrativa, núm. 271-272, 2005, págs. 81-101. QUADRA-SALCEDO JANINI, T. de la, y SUÁREZ CORUJO, B., "La garantía de los derechos sociales en la Constitución europea: la consagración de la dependencia como contingencia protegida por los sistemas de Seguridad Social”, Revista del Ministerio de Trabajo y Asuntos Sociales, núm. 57, 2005, págs. 471-502.

${ }^{8}$ Nos remitimos a las consideraciones al respecto de MARTIN REBOLLO, L., en su muy reciente libro sobre La autonomía de Cantabria (1981-2008). Una radiografía institucional. Una reflexión prospectiva, Parlamento de Cantabria, Santander, 2008, págs. 171 y ss. 
Pero los factores negativos se han concentrado en un tracto temporal inusitadamente breve. Comienza con el fracaso de la Constitución europea y, casi coetáneamente, con el golpe infligido por la Corte Costituzionale al contenido dogmático de los nuevos Estatutos italianos, reduciéndolo prácticamente a la nada. A ello se une la tremenda crisis económica que súbitamente da la cara en los comienzos del verano de 2007; y al término de este mismo año la STC 247/2007 pone sordina a lo que dicen los Estatutos sobre todo derecho que no sea de corte estrictamente institucional, haciéndolo con una argumentación muy discutible, aunque posiblemente movida por el temor no confesado de que el Estado quede cautivo de sus propias leyes orgánicas aprobatorias de los Estatutos, en perjuicio de las competencias estatales mismas.

En fin, esta última reflexión nos coloca ante la paradoja quizás más destacable de la Sentencia referida. Su corte aperturista a la entrada en los Estatutos de contenidos distintos a los expresamente contemplados en la Constitución induce a pensar prima facie en un respaldo categórico hacia las flamantes Cartas estatutarias de derechos, falsa impresión que la propia Sentencia deja a la postre disuelta como un azucarillo, como veremos en su lugar.

Pero antes que nada conviene situarse en la realidad anterior en el tiempo a los nuevos Estatutos de Autonomía porque esa realidad invita a contemplar el panorama no sólo desde la altura de las abstracciones, sino también desde el suelo. Por eso queda situada al comienzo del discurso, como objeto del epígrafe siguiente.

\section{LA LEGISLACIÓN AUTONÓMICA, FACTOR DE IMPULSO Y CONCRECIÓN DE LOS DERECHOS SOCIALES. UNA IMPRON- TA SOBRE LA LABOR REALIZADA POR LAS COMUNIDADES AUTÓNOMAS EN ESTE ÁMBITO}

\section{Consideraciones generales}

Lo que habremos de señalar aquí de ningún modo supone minimizar el trascendente papel desempeñado por el Estado y su Administración en el campo de la acción social; pero no es ésta la vertiente que hay que considerar en esta ocasión, sino el impulso dado a estas políticas por las Comunidades $\mathrm{Au}-$ tónomas.

Puede afirmarse que la tendencia hacia la tutela de los derechos sociales ha sido tónica común en los territorios, sin que se aprecien sensibles diferen- 
cias entre ellos; si se observa atentamente la legislación autonómica aparecida no cabe decir otra cosa. Pero quede claro que la anterior afirmación se circunscribe al hecho mismo de la producción normativa sobre la materia y no prejuzga sobre el grado de eficacia real y la calidad que la acción social prestadora haya alcanzado en cada Comunidad Autónoma. El número de leyes aprobadas por cada Parlamento autonómico no es un dato elocuente por sí mismo para poder deducir el nivel en que se encuentran las políticas sociales o el esfuerzo financiero puesto por cada Comunidad al servicio de estos objetivos, pues bien se sabe cuánto mimetismo guía la producción de este tipo de legislación y cuán proclive es ésta a ser utilizada como bandera. Pero tampoco es razonable hacer abstracción de tal dato, por su valor al menos indiciario de la sintonía con este orden de preocupaciones.

Existen más de tres centenares de leyes autonómicas en vigor producidas desde el inicio del sistema, ello sin contar las leyes que tienen por exclusivo objeto crear centros o servicios ad hoc ni las muchas disposiciones reglamentarias que concurren con las leyes en la regulación de estas materias. Se encuentran a la cabeza, en cuanto a número de leyes sociales aprobadas, por este orden, las Comunidades Autónomas de Madrid, Valencia y Cataluña, que rebasan sobradamente cada una de ellas la veintena de disposiciones con rango de ley, cifras que duplican prácticamente las leyes sobre la materia aprobadas por la Comunidad de La Rioja y la Región de Murcia, que son las que registran menor actividad al respecto, e incluso las de Asturias y Canarias, también situadas en números relativamente menores.

De ese voluminoso banco normativo pueden extraerse conclusiones de notable interés, siempre considerando esa labor legislativa como un todo y sin descender a particularizaciones ni a comparar lo hecho o lo dejado de hacer por Comunidades Autónomas determinadas. De este modo, dos órdenes de cuestiones cabe plantear a la vista de ese abigarrado conjunto de leyes; el primero se relaciona con el objeto mismo de esas leyes, qué tipo de derechos enuncian, cómo suelen quedar organizados desde el punto de vista formal; el segundo supone dar un paso más: analizar la estructura interna de las normas contenidas en dichas leyes y deducir cuál sea su eficacia jurídica real y la posición de los ciudadanos en cuanto a la exigibilidad de lo que dichas leyes proclaman o dicen reconocer o garantizar. A estos dos grandes aspectos nos referimos a continuación.

\section{Objeto y estructura de las Leyes Autonómicas sobre la materia}

El grueso de las leyes dictadas tiene por objeto las materias que la Constitución contempla como principios rectores de la política social y económica 
(Cap. III, Tít. I), lo cual quiere decir que prácticamente no se observan derechos sociales nuevos que no puedan vincularse de algún modo con los mencionados en dicho Capítulo. Dicho lo anterior conviene aclarar que esa correlación entre las materias reguladas por las leyes autonómicas y el referido Capítulo de la Constitución es una concordancia relativa puesto que en numerosos casos esos principios son convertidos por las leyes autonómicas en derechos, lo cual significa que en el proceso de impulso dado por las Comunidades Autónomas al postulado del Estado Social, el desarrollo de los principios rectores constitucionales ha cubierto en tales casos la totalidad del camino posible, o sea, no se ha quedado en cualquier punto anterior a su cristalización como derechos públicos subjetivos plenos y perfectos.

No son muchas las leyes autonómicas que desarrollan o especifican de modo frontal y directo los genuinos derechos fundamentales que se contienen en el Capítulo II del mencionado Título I de la Constitución, ni siquiera los que dentro de ese Capítulo II son calificables a la vez como derechos sociales (derechos de participación y de acceso a los cargos públicos, educación, sindicación, huelga...) desarrollo que podrían hacer perfectamente, siempre que la Comunidad Autónoma contase con competencia para ello y no se menoscabasen lo más mínimo los propios derechos fundamentales, pues ésta debe considerarse condición sine qua non para que el desarrollo del derecho fundamental hecho por una ley autonómica -o por una ley orgánica aprobatoria de Estatuto de Autonomía- pueda reputarse lícito en términos constitucionales. Hay que citar en este apartado las leyes referidas a la igualdad entre mujeres y hombres, dictadas hasta el momento en siete Comunidades Autónomas. También han de integrarse en este grupo, por entroncar con el artículo 15 de la Constitución (derecho a la vida y a la integridad física y moral), las leyes autonómicas que en número de media docena establecen medidas protectoras contra los malos tratos y la violencia doméstica, así como las leyes que en igual número regulan la llamada voluntad anticipada o testamento vital, cuya regulación aparece de ordinario en apartados específicos de otras leyes que tienen por objeto central la protección de la salud. Quede anotado el dato de las muy escasas leyes que desarrollan el derecho a la educación obligatoria ex art. $27 \mathrm{CE}$-un derecho fundamental clasificable además entre los derechos sociales-, siendo más numerosas las leyes que se ocupan de promocionar la educación de adultos, materia ésta que conecta con el derecho de acceso a la cultura que luce como principio rector en el artículo 44.1 CE.

Aparte de lo anterior, hay que tener muy en cuenta que el desarrollo o especificación de derechos fundamentales se produce también no de modo directo sino a través de infinidad de normas que al regular materias de índole 
social del más variado tipo (asistencia social, protección de la familia, drogodependencias, minusvalías, salud, etc.) establecen un vínculo o puente preciso entre el asunto objeto de regulación -por ejemplo, la protección del menor- y algunos o la mayoría de los derechos fundamentales enumerados en la Constitución, de tal modo que la tabla de derechos resultante, en este caso del menor, viene a tener la estructura de una especie de mini Constitución adaptada a las peculiaridades que ofrecen las necesidades de los menores (derecho a la igualdad, a no sufrir malos tratos, a la educación, derechos de asociación y reunión, etc., etc.). Así, nos encontramos ante un inmenso panorama de transposiciones indirectas de derechos constitucionales realizadas de forma masiva por estas leyes autonómicas reguladoras de derechos sociales determinados. De estas conexiones entre la materia social y los derechos fundamentales resultan unas combinaciones en número tan elevado que los derechos subjetivos resultantes, perfectamente perfilados e independientes entre sí, podrían contarse no ya por cientos, sino por miles. He aquí, por tanto, la visión del espectáculo en que consiste el resultado final del proceso de especificación de esos derechos fundamentales por las leyes autonómicas. Bien se ve que los derechos fundamentales están dotados de un poder de irradiación formidable, aunque aparezcan en la Constitución tan simples e incluso lacónicos. Esas leyes han ido extrayendo de ellos sus potencialidades, sacando a la luz sus facetas ocultas y haciéndolas brillar.

Pero esta traslación de derechos fundamentales no se produce sólo a través de estas leyes que tienen por objeto la regulación de derechos sociales sino también por vía de otras leyes autonómicas de objeto diverso (electorales, de régimen jurídico, procedimentales, de ordenación lingüística, de función pública, de protección de datos...) comprensivas de preceptos que guardan conexión cierta con tales derechos fundamentales. Ocurre esto, señaladamente, con el derecho de participación en asuntos, funciones y cargos públicos (art. $23 \mathrm{CE}$ ), especialmente susceptible de diversificación y desarrollo, dados los muchos aspectos que engloba (derecho a ser elector y elegible, al acceso a los empleos públicos en condiciones de igualdad, mérito y capacidad, derecho de acceso a los documentos, derecho a una buena Administración, etc.).

Dejando ya al margen esa interrelación entre leyes sociales y derechos fundamentales y volviendo a las características que ofrece la legislación social autonómica, en aras de la concisión valga afirmar con cierta rotundidad que los pilares fundamentales de todo ese edificio normativo son tres, cada uno de los cuales ofrece unas características propias que ayudan a comprender el conjunto. Son: a) sanidad, b) asistencia social y c) protección de los menores. Existen 
dos buenas razones para destacar las áreas referidas: por una parte, exigen un gran despliegue de medios, sean dinerarios o de carácter técnico, por lo que constituyen el ejemplo vivo de la "prestación" pública definidora del Estado Social; y, por otra parte, algo tan importante como lo anterior: de esas leyes se desprende del modo más palpable un firme compromiso tanto en el establecimiento mismo de esas prestaciones como en su mantenimiento y mejora progresiva, dato éste que tiene mucho que ver con el reconocimiento de derechos públicos subjetivos en favor de los ciudadanos y que no se da, al menos con la misma intensidad, en otros sectores de la acción social, como habremos de ver más adelante.

a) El primer pilar lo compone la normativa sobre salud o sanidad, una auténtica constelación autónoma y separable del resto de la acción social y con una gran capacidad de percusión sobre los más diversos derechos fundamentales, comenzando por el derecho a la vida y todo lo que actualmente se mueve en su entorno (eutanasia, muerte digna, testamento vital, etc.) y terminando por derechos de corte administrativo, aunque también importantes (acceso al historial clínico, a su archivo y conservación, etc.).

Todas las Comunidades Autónomas -operando básicamente sobre su competencia en materia de "Sanidad e Higiene" (art. 148.1.21 ${ }^{\mathrm{a}} \mathrm{CE}$ ) y la de desarrollo de las bases estatales sobre sanidad (art. 149.1.16 ${ }^{a} \mathrm{CE}$ ) - cuentan con leyes de cabecera en este ramo. Además, existen otras leyes autonómicas que en número diverso, reducido por lo general, vienen a complementar esas normas centrales sobre la materia, destacando las que versan sobre la salud escolar y sobre los derechos e información del paciente, siendo más escasas las que tienen por objeto específico la regulación de las listas de espera, la salud mental o la regulación de bancos de sangre y tejidos.

Todas las leyes de cabecera de los sistemas autonómicos de salud contienen largas listas de enunciados, formulados como derechos, de tal modo que de la yuxtaposición de dichas listas resultaría un catálogo de derechos relativos a la salud de dimensiones considerables. En ese panorama tan dispar juega como denominador común la Ley General de Sanidad con su catálogo de derechos (art. 10) más los incorporados por la Ley de Cohesión y Calidad del Sistema Nacional de Salud (art. 4) ${ }^{9}$.

${ }^{9}$ Vid. ÁLVAREZ GONZÁLEZ, E. M., Régimen jurídico de la asistencia sanitaria pública. Sistema de prestaciones y coordinación sanitaria, Comares, Granada, 2007, págs. 243 y ss. Además, vid. infra nota 21. 
Pero a los efectos que aquí nos interesan, este sector ofrece la mejor prueba sobre cómo se estructuran los derechos y cómo se consuma el proceso de especificación de derechos fundamentales, hasta llegar a sus últimos extremos. En efecto, algunas de esas leyes optan por el método de hacer una larga relación de derechos, expresados de un modo muy breve e incluso solemne, lo cual realza el tono categórico de los enunciados pero a la vez deja huecos importantes a rellenar. En cambio, otras leyes siguen un método distinto y sin duda más perfecto y fiable que el anterior consistente en relacionar en primer lugar una serie de derechos básicos -una especie de "parte general"- (derecho a la asistencia sanitaria, a obtener información de los servicios sanitarios a los que se puede acceder, a obtener la Carta de derechos y deberes que rigen los centros sanitarios, a ser atendidos sin discriminación y con respeto a la intimidad y dignidad humana, a realizar reclamaciones y sugerencias... y un largo etcétera); y a continuación una tanda de derechos específicos aunque de amplio espectro que se regulan "monográficamente" en artículos independientes e incluso en capítulos $a d$ hoc. Cada uno de estos subsectores del derecho principal -que es el derecho a la salud- es susceptible de ser dividido en otros particulares, y en muchos casos estos últimos también quedan escindidos en otros aún más pequeños, todo lo cual nos ofrece un panorama de creación de derechos en racimo donde cada elemento genera otras piezas y así sucesivamente. Así, en este sector salud hay un grupo de derechos específicos de "primer nivel"10 cada uno de los cuales se diversifica y concreta del modo sucesivo antes referido ${ }^{11}$.

\footnotetext{
${ }^{10}$ Derechos relacionados con el nacimiento; información asistencial; promoción y protección de la salud y la prevención de la enfermedad; igualdad y la no discriminación de las minorías; acceso a la atención sanitaria; derechos específicos de los enfermos mentales; los relacionados con la educación para la salud; derechos a programas y actuaciones especiales y preferentes; de los enfermos en fase Terminal; relativos a la autonomía del paciente; a la expresión de la voluntad anticipada; los relacionados con la intimidad y con la confidencialidad; derecho al acompañamiento; al acceso a la documentación o historia clínica; relacionados con la investigación y experimentación científica...

${ }^{11}$ Baste citar, a título de ejemplo, los derechos relacionados con el nacimiento donde se distinguen la serie de derechos específicos referidos a la madre, al recién nacido y a los padres en común; o los derechos relativos a la autonomía del paciente, del que se desprenden los derechos relacionados con el consentimiento informado, y los que se desprenden a su vez de éste (elegir entre opciones médicas o quirúrgicas, etc.), hasta llegar a sus últimas especificaciones, tales como el derecho a prestar el consentimiento a través de representante, consentimiento de los menores, etc.
} 
b) El segundo basamento lo constituye necesariamente la legislación sobre asistencia social $^{12}$, que en puridad es el tronco de la acción social de los poderes públicos y cuyas ramas se extienden o pueden extenderse horizontalmente hacia las áreas especiales o colectivos determinados de personas que, además, suelen venir regulados por leyes específicas, que así resultan ser elementos desgajados de la ley de cabecera, esto es, la ley de Asistencia social de que se trate.

Todas las Comunidades Autónomas sin excepción cuentan con su respectiva Ley reguladora de la asistencia social, leyes que en su mayoría contienen generosas relaciones de derechos. Son acompañadas en algunas Comunidades Autónomas de otras leyes que regulan aspectos específicos de la materia, tales como los que se ocupan específicamente de las prestaciones económicas, la inserción social, la organización de los Centros y Servicios, el apoyo a las familias, etc. Cabe dejar anotado, por su alta significación en el campo de los derechos sociales, que son aún pocas las Comunidades Autónomas que han abordado directamente, mediante ley, la llamada "renta mínima de inserción" o "ingresos mínimos de subsistencia", destinada a las personas carentes de recursos que se encuentran fuera de la órbita del mercado de trabajo y en situación de exclusión social, objetivo que en cambio sí aparece en todos los Estatutos de Autonomía de la nueva serie, proclamado, ora como derecho, ora como principio rector. Esta imagen normativa que ofrece la renta de subsistencia es similar a la que muestran las situaciones de dependencia, con la particularidad de que no existen específicas leyes autonómicas que regulen estas situaciones, ni todos los nuevos Estatutos de Autonomía se han hecho eco de esta responsabilidad, lo que tampoco prejuzga nada pues claro está que la atención real a un problema social no depende de la proclamación que de ello haga o no un Estatuto sino de la puesta en práctica de las competencias que en su caso la Comunidad Autónoma tenga sobre el particular ${ }^{13}$.

${ }^{12}$ Sobre el tema, PEMÁN GAVÍN, J. M., "El marco jurídico de la asistencia social en España: Competencias, principios y modalidades de la acción administrativa" en Revista Aragonesa de Administración Pública, 23, 2003; del mismo autor voz "Asistencia Social", en Diccionario de Derecho Administrativo, Tomo I, Iustel, Madrid, 2005; "La asistencia social en España: Delimitación conceptual y marco jurídico general" en Documentación Administrativa, núm. 271-272, 2005 y VAQUER CABALlERÍA, M., La acción social (un estudio sobre la actualidad del Estado social de Derecho), Institut de Dret Public, Tirant lo Blanch, Valencia, 2002.

${ }^{13}$ Sobre los especiales problemas de competencia que ha planteado la Ley 39/2006 de 14 de diciembre de Promoción de la Autonomía Personal y Atención a las personas en situación de dependencia, vid. MONTILLA MARTOS, J. A., "El debate competencial en torno a la Ley de Dependencia” en Informe Comunidades Autónomas 2006, Instituto de Derecho Público, Barcelona, 2007, págs. 853 y ss. Las publicaciones sobre este sector son ya muy numerosas. 
En términos generales, la estructura de esas leyes o, dicho de otra forma, el método utilizado para expresar el reconocimiento de los derechos, es análogo al del sector salud. Presentan, pues, una larga lista de derechos básicos ${ }^{14}$ más las regulaciones monográficas de derechos específicos (derechos de la familia, la infancia y la adolescencia, derecho a la información, prestaciones para las situaciones de dependencia) a los que hay que sumar los derechos relativos a las personas usuarias de centros y de servicios de atención diurna y nocturna, bloque éste que constituye un microcosmos de derechos del más variado tipo, señaladamente derechos fundamentales, ello inherente al hecho de la integración de la persona en una organización y un espacio físico y su convivencia con otras personas.

c) El tercer pilar puede representarlo la normativa relativa a la protección de los menores. Es válida como muestra, precisamente por tratarse de una regulación muy desgajada de la normativa troncal -la asistencia social-y porque todas las Comunidades Autónomas tienen sin excepción su ley principal sobre menores, a la que, incluso, se unen salpicadamente otras leyes especiales que regulan singularmente aspectos tales como la adopción de los menores o las medidas para protegerlos de las bebidas alcohólicas. Por tanto, un sector especial que genera sus propias leyes especiales. Aparte de ello, es un sector muy destacable porque las leyes que se refieren a los menores proclaman sus derechos con especial intensidad, llegando incluso a una minuciosidad rayana en la utopía.

Como ya advertimos supra las leyes autonómicas sobre protección de menores, en su mayoría, hacen una completa trasposición de derechos fundamentales aplicados a la infancia (civiles, políticos, económicos, laborales, sociales), amén de otros nacidos de la inventiva -a veces ilusoria- de los legisladores autonómicos ("derecho a conocer su pueblo o ciudad", "a vivir en un entorno acorde con sus necesidades propias", etc.). Pues bien, si tenemos en cuenta que dentro de esa tan extensa tabla de derechos se integran, como no podría ser de otro modo, el derecho a la salud, a la asistencia social, a la edu-

${ }^{14}$ Derechos al acceso a los servicios, a recibir un trato debido, a la protección ante situaciones de desventaja derivadas de carencias básicas o esenciales, protección de la infancia y la adolescencia en situaciones de riesgo y desamparo, protección ante situación de riesgo social con medidas encaminadas a la inclusión social, a recibir atención urgente prioritaria...; amén de toda la serie de derechos que son traducción de derechos fundamentales: a la libertad religiosa, ideológica y de culto, al secreto de las comunicaciones, derecho de asociación, etc. 
cación, etc. - tan expansivos en cuanto a su capacidad para proyectar nuevos derechos en todas direcciones-, bien puede comprenderse que la panorámica que se abre ante la vista es realmente inmensa.

Aparte de estos que hemos denominado pilares básicos de la normativa social existen otros sectores que han contado con una atención del legislador autonómico, si no igual, sí aproximada. Pueden situarse en un muy digno segundo nivel los conjuntos de leyes autonómicas que se ocupan de los minusválidos, señaladamente en lo que concierne a la supresión de barreras arquitectónicas y al uso de los perros guía, ya que no han proliferado precisamente leyes autonómicas que aborden los problemas de los minusválidos de modo específico e integral ${ }^{15}$ aunque -ocioso es reiterarlo- exista una normativa fragmentaria sobre esta área de atención, al igual que ocurre con otras áreas, dispersa por las distintas leyes autonómicas principales que regulan la acción social más generalizada a las que ya nos hemos referido: salud, asistencia social, menores, educación, etc. En este mismo nivel cabe situar la producción legislativa dirigida a atajar las drogodependencias, siendo aún mayor la dedicada a los servicios de empleo ${ }^{16}$ así como a la protección de los derechos de consumidores y usuarios $^{17}$; y cabe incluir también en este importante segundo grupo el con-

\footnotetext{
${ }^{15}$ Es ejemplo muy positivo en este sentido la Ley de la Comunidad Valenciana 11/2003, de 10 de abril, que amén de enunciar una tabla básica de derechos (acceso en condiciones de igualdad a los servicios públicos, diagnóstico precoz, trato personalizado, asesoramiento psicosocial, etc.) aborda monográficamente áreas específicas de atención: la materia educativa, en materia de rehabilitación, derechos de los padres y familiares, más todo lo concerniente a la estancia en residencias para personas incapaces y demás centros de atención, lo cual genera toda una estructura de derechos en racimo como ya expusimos más arriba en relación con el derecho a la salud.

${ }^{16}$ La acción social para el empleo, en cuanto al reconocimiento de derechos, no tiene las dimensiones que venimos predicando de casi todos los demás sectores. Así, la tabla se reduce prácticamente a los derechos de información, no discriminación, confidencialidad y respeto a la intimidad personal.

${ }^{17}$ En este sector pueden detectarse tres vertientes en cuanto al tipo de derechos reconocidos. Los que se predican propiamente de los consumidores y usuarios (protección jurídica y reparación o indemnización por daños; información en materia de precios -que genera una serie muy numerosa de derechos- más todo el acervo de garantías que derivan de las relaciones contractuales inherentes a la materia, lo que abre un horizonte de derechos casi inabarcable); los derechos que se reconocen a las Asociaciones de Consumidores y usuarios (representación de los consumidores, declaración de utilidad pública, solicitar ayudas, ejercer derecho de audiencia y acciones populares, participar en el sistema arbitral de consumo, etc.); y una tercera rama referida a la educación y formación en materia de consumo.
} 
junto de leyes relacionadas con la protección de la familia (mediación familiar, parejas de hecho, igualdad de la mujer) y el que se ocupa del voluntariado ${ }^{18}$ sobre el que existen leyes específicas prácticamente en todas las Comunidades Autónomas.

A partir de este nivel, la envergadura del panorama normativo desciende de manera notable. Así, puede situarse en un tercer nivel la serie de leyes producidas en relación con la atención a los mayores y cabe incluir en este mismo plano las relativas a la promoción de la juventud, pues aunque superiores en número son normas de menor "densidad" en cuanto al peso de las obligaciones ciertas que se contraen ante los posibles beneficiarios de este tipo de acciones. Y lo mismo puede decirse de las leyes que aluden al derecho a la vivienda, ricas en número pero pobres por lo general en cuanto al reconocimiento de derechos subjetivos a la prestación. En este mismo nivel cabe situar la legislación autonómica medioambiental. Y ya en un lugar residual la legislación relativa al patrimonio y la cultura (leyes de patrimonio histórico y del patrimonio cultural, de museos, bibliotecas, archivos, fomento del libro y la lectura, y cultura popular) ramas éstas en que los supuestos derechos de los ciudadanos se tornan algo borrosos como tales derechos sociales. Finalmente, no podrían dejar de mencionarse las dos Comunidades Autónomas (Navarra y País Vasco) que tienen aprobadas, mediante ley, Cartas de derechos sociales.

El anterior retablo trata de dar sólo la impronta cuantitativa de las leyes autonómicas dictadas en materia de derechos sociales así como una explicación aproximada de cómo se organiza esa red de derechos. Pero sobre todo trata de hacer patente la voluminosidad que ya ha alcanzado el fenómeno y que sirva para acreditar que cuando se habla de derechos sociales no se está aludiendo a algo abstracto que se encuentre aún entre las musas o que sea un hallazgo que estén alumbrando las tablas de derechos de los nuevos Estatutos de Autonomía sobre las que tanto se viene discutiendo. Pero más importante

$18 \mathrm{Al}$ igual que el anteriormente anotado, la legislación sobre voluntariado social también se proyecta en tres vertientes diferentes: en la proclamación de los derechos de los voluntarios cuyos obligados son por lo general sujetos privados, y que componen una larga lista (derechos de formación y disposición de medios necesarios, al aseguramiento, al resarcimiento de gastos realizados, etc.); derechos de los destinatarios de la acción voluntaria (a recibir información, a un trato digno, a que la acción voluntaria se desarrolle de acuerdo con los programas o proyectos previstos); derechos reconocidos a las entidades de voluntariado, esto es, las responsables de los proyectos correspondientes (solicitar medidas de apoyo y fomento para la actividad, reconocimiento del interés social de sus cometidos, etc.). 
aún que esta impronta formal de esa realidad legislativa es captar cuál sea a la postre el alcance de los derechos proclamados a favor de los ciudadanos y de las obligaciones contraídas por los poderes públicos; lo que abordamos a continuación.

\section{Valor y eficacia jurídica de los derechos sociales creados por la Legislación Autonómica}

Por vía de síntesis puede afirmarse lo que sigue:

a) Una observación atenta de ese cúmulo de leyes autonómicas permite advertir, en primer lugar, la resolución con la que proclaman derechos subjetivos a favor de los beneficiarios. Por tanto, la tónica no es la simple promoción de acciones sociales positivas -opción en todo caso lícita y encomiablesino la creación de auténticas obligaciones para con los beneficiarios de éstas. Esto puede ya predicarse de entrada de los tres sectores básicos garantizados: pensiones de la Seguridad Social, salud y educación ${ }^{19}$. Pues bien, la mayoría de las leyes autonómicas utilizan con toda frecuencia fórmulas "sacramentales" con las que se suelen consagrar los derechos subjetivos ("Todos tienen derecho..."; "Se reconoce -o se garantiza- el derecho..."; y cláusulas análogas). Es cierto que el uso de estas fórmulas no es factor definitivo para tener un derecho por nacido, pues consabido es cómo está enquistada en esta materia social el uso del "derecho-aspiración", pero puede afirmarse con todo énfasis que los derechos proclamados en tales leyes son por lo general auténticos derechos, tanto por lo que los preceptos dicen como por el fondo normativo que los acompaña.

Tales fórmulas rituales no son condición suficiente para la creación de derechos, pero tampoco son condición necesaria, pues existen no pocas leyes que sin hacer proclamaciones especiales crean efectivamente derechos al regular cumplidamente la prestación de que se trate, determinando claramente los requisitos objetivos necesarios para su disfrute. Al tratarse de regímenes jurídicos reglados y no discrecionales -éstos serían difícilmente compatibles con el principio de igualdad- la figura del derecho subjetivo queda formada, si bien indirectamente, a lo que hay que añadir los derechos reaccionales dimanantes de la legalidad conculcada, concretamente de la infracción al principio

\footnotetext{
19 Vid. en este sentido TORNOS MAS, J., "Efectividad de los derechos y exigibilidad de los servicios sociales” en Documentación Administrativa, núm. 271-272, 2005, pág. 375.
} 
de igualdad, como ya advirtiera ESCRIBANO COLLADO respecto al acceso a las prestaciones sanitarias ${ }^{20}$. En suma, se quiere decir que son bastante superiores en número las leyes sociales autonómicas que establecen derechos subjetivos en comparación con las que cumplen los postulados del Estado social a un nivel menos pleno.

b) Otro rasgo que llama considerablemente la atención es la desigual presencia de derechos subjetivos en los distintos sectores de la acción social, de tal modo que en algunos de ellos se dan con profusión mientras que en otros están prácticamente ausentes. De dichos sectores sobresale el de salud, donde las leyes de casi todas las Comunidades Autónomas configuran las prestaciones como derechos, del modo más inequívoco ${ }^{21}$. Igual sucede, aunque en tono algo inferior, en el ámbito de la protección de los menores que confirma así su posición destacada en el mundo de los derechos sociales; y en el mismo nivel puede situarse la legislación sobre protección y defensa de consumidores y usuarios, sector éste donde los muy numerosos derechos subjetivos que se crean o reconocen tienen generalmente como sujetos obligados a terceros privados, razón por la que no representan compromisos financieros para los poderes públicos que los establecen. Igual ocurre con la legislación sobre el voluntariado en la que abunda el reconocimiento de derechos subjetivos -a favor de los voluntarios y de las personas beneficiarias de la acción- pero no en cuanto a las relaciones entre las entidades de voluntariado y la Administración, ya que éstos discurren por vía de subvenciones y en función de las disponibilidades presupuestarias. También suponen cargas para terceros en gran medida

${ }^{20}$ El Derecho a la salud, Cuadernos del Instituto García Oviedo, núm. 1, Sevilla 1976, págs. 50 y ss. Vid. asimismo GARCÉS SANAGUSTÍN, A., Prestaciones sociales, función administrativa y derechos de los ciudadanos, cit., pág. 176. Para el tema en general es obligada la cita de GARCÍA DE ENTERRÍA, E., "Sobre los derechos públicos subjetivos", en REDA, núm. 7, 1975.

${ }^{21}$ Pueden citarse por su expresividad la Ley 3/2003 de 10 de abril de la Región de Murcia y, desde luego, la Ley 2/2007 de 27 de marzo de la Comunidad de Cantabria. Como ya quedó dicho supra hay un denominador común formado por la Ley General de Sanidad y la Ley de Cohesión y Calidad del Sistema Nacional de Salud con sus respectivas tablas de derechos, configurados como auténticos derechos subjetivos exigibles ante los tribunales (art. 1.4 LES) no obstante las carencias que presentan algunos de estos derechos en cuanto a su desorden reglamentario, lo que afecta a su eficacia real. Vid. la crítica en este sentido de ÁLVAREZ GONZÁLEZ, E. M., Régimen jurídico de la asistencia sanitaria..., cit. pág. 246. Sobre la consolidación de las prestaciones sanitarias como derecho subjetivo, VIDA FERNÁNDEZ, J., en el libro coord. por Luciano Parejo, Alberto Palomar y Marcos Vaquer, La reforma del Sistema Nacional de Salud, Marcial Pons-Departamento de Derecho Público del Estado, Universidad Carlos III, Madrid, 2004. 
-salvo que se trate de sitios o servicios públicos- la protección de los minusválidos en lo atinente a la supresión de barreras y asistencia de perros-guía. En la legislación que tiene por objeto la asistencia social es más reducido el número de leyes autonómicas que proclaman derechos subjetivos, aunque algunas de ellas son auténticamente ejemplares desde este punto de vista.

Fuera de los sectores citados las leyes autonómicas son mucho más "moderadas" o cautelosas a la hora de definir la prestación de que se trate como derecho subjetivo, limitándose por lo general a regular las actividades y la organización de los servicios al respecto. Esto se produce en sectores tan señalados como el de atención a las drogodependencias (aunque no faltan leyes que reconozcan derechos subjetivos de los afectados ${ }^{22}$ y de minusválidos, también con algunas excepciones. Aparte de ello y siempre desde la dificultad de sentar conclusiones precisas desde el ingente material legislativo en presencia, cabe finalizar este breve balance señalando sectores prácticamente huérfanos de reconocimientos de derechos subjetivos -salud escolar, promoción de la juventud, educación de adultos, vivienda, medio ambiente, cultura (bibliotecas y museos), patrimonio cultural e histórico-, junto a otros donde brillan meritorias leyes reconocedoras de derechos subjetivos sobre prestaciones que denotan una alta implicación social. Así, además de los derechos a prestaciones de asistencia social reconocidos en un buen número de Comunidades Autónomas en sus leyes de cabecera, leyes especiales de atención a los minusválidos como las de Andalucía y Comunidad Valenciana ${ }^{23}$, de reconocimiento de la renta de ciudadanía, y de apoyo a las familias, de Cataluña ${ }^{24}$, o de protección de ancianos de Castilla y León, ramo en el que también debe destacarse la legislación de Cataluña y Extremadura ${ }^{25}$.

c) Según venimos de relatar, a la vista del panorama legislativo autonómico, muy en síntesis descrito, puede afirmarse que la presencia de la garantía del derecho subjetivo a las prestaciones está notablemente arraigada, espe-

22 Así, Ley 18/1998 de 25 de junio del País Vasco, 5/2001 de 17 octubre de La Rioja, 1/2003 de 28 de enero de la Comunidad Valenciana y 4/2005 de 29 abril de las Islas Baleares.

${ }^{23}$ Leyes 1/1999 de 31 marzo y 11/2003 de 10 abril, respectivamente.

${ }^{24}$ Leyes 10/1997 de 3 julio, cuyo artículo 6 contempla los requisitos objetivos que dan derecho a la prestación automáticamente y 18/2003 de 4 julio.

${ }^{25}$ Ley 5/2003 de 3 abril de Castilla y León; 22/2000 de 29 diciembre de Cataluña y 2/1994 de 28 abril de Extremadura. 
cialmente en sectores "estrella" de la acción social. Pero para sentar conclusiones fiables no basta con fijarse en la dicción de los preceptos que enuncian esos derechos, debiendo comprobarse si existen en esas mismas leyes otros preceptos que alteren esas enfáticas proclamaciones. Pues bien, aunque no en abundancia sí existen reglas que o bien ratifican o bien relativizan la fuerza de tales declaraciones.

En relación con las primeras, se dictan cláusulas de refuerzo de la garantía de las prestaciones y la responsabilidad pública al efecto ${ }^{26}$ o se delimitan las prestaciones garantizadas o sujetas a las disponibilidades presupuestarias, mediante las oportunas "carteras de servicios" sociales ${ }^{27}$ o se hacen remisiones a reglamentos para que éstos fijen el contenido de los derechos reconocidos por la Ley y establezcan los procedimientos y garantías para su efectividad ${ }^{28}$, o se dictan directrices positivas de orden presupuestario ${ }^{29}$ y para la mejora progresiva de las prestaciones ${ }^{30}$; o, en fin, se proclama lisa y llanamente el carácter reglado y no graciable de las prestaciones ${ }^{31}$. En suma, el panorama ofrece un perfil muy positivo y concuerda con la apreciación que ya hiciera TORNOS MAS sobre la tendencia normativa a configurar como verdaderos derechos subjetivos prestaciones en materia de servicios sociales que antes tenían carácter graciable ${ }^{32}$.

${ }^{26}$ Ley 7/2003 de 9 diciembre de Sanidad de Galicia (art. 132); Ley 12/2007 de 11 de octubre de Servicios Sociales de Cataluña (art. 5c).

${ }^{27}$ Ley Foral 15/2006 de 14 diciembre, de Servicios Sociales de Navarra (art. 19); Ley 2/2007 de 27 marzo de Servicios Sociales de Cantabria. La Ley 13/2006 de 27 julio de Prestaciones Sociales de Carácter Económico de Cataluña hace relación de las "prestaciones de derecho subjetivo" de esta clase (art. 19 a 22).

28 Así, Ley 8/2003 de 8 abril, de Castilla y León; Ley 4/2005 de 29 abril de Drogodependencias de las Islas Baleares; Ley 1/1998 de 20 abril de los Derechos y la Atención al Menor, de Andalucía y Decreto 42/2002 de 12 febrero, dictado en desarrollo de aquélla.

${ }^{29}$ La Ley 14/2002 de 25 julio de Castilla y León, relativa a la protección de la infancia establece la prioridad presupuestaria para estos fines (art. 6).

${ }^{30}$ Ley 9/1991 de 2 octubre de Inserción Social de Galicia (Dispos. Trans. $1^{\text {a }} .2$ ); Ley 15/1990 de 9 julio de Sanidad de Cataluña (Dispos. Adic. 4a); Ley 9/1999 de 9 abril, del Instituto Aragonés de Empleo (Dispos. Adic. $3^{\mathrm{a}}$ ).

${ }^{31}$ Ley 4/1987 de 25 marzo de Acción Social de Aragón (art. 3.f); Ley 18/1998 de 28 diciembre de Servicios Sociales de Castilla y León; Ley 3/2003 de 10 abril de Murcia.

32 "Efectividad de los derechos y exigibilidad de los servicios sociales", cit. págs. 378 y ss. 
Pero aun siendo cierto lo anterior no cabe marginar el hecho de que un número estimable de leyes, aunque no excesivo, hace remisión a la cláusula de salvaguarda de las "disponibilidades presupuestarias". Pero en esto hay que matizar debidamente porque la remisión a esta cláusula -utilizada muchas veces como muletilla o fórmula de estilo- no siempre es utilizada por el legislador con el fin de condicionar el valor del derecho subjetivo proclamado ${ }^{33}$, aunque en otros casos sí tiene claramente esa finalidad ${ }^{34}$; y ya dentro de esta última hipótesis también es preciso seguir matizando al objeto de calibrar el verdadero tamaño del fenómeno, distinguiendo, pues, cuándo ese condicionamiento de orden presupuestario se predica por la ley de los derechos subjetivos (con lo cual dejan de ser, en puridad, derechos subjetivos) y cuándo de los principios rectores (algo que les cuadra perfectamente, vista su naturaleza) ${ }^{35}$. $\mathrm{Y}$ ya dentro de esos "derechos subjetivos" condicionados por las disponibilidades presupuestarias, hay que distinguir si están afectados todos los contemplados por la ley de que se trate, o sólo algunos de ellos, supuesto éste harto frecuente.

\footnotetext{
${ }^{33}$ Se trata, en efecto, de cláusulas generales dirigidas más a la organización de los servicios que a los concretos derechos que esas leyes proclaman. Así, p. ej., Ley 55/1997 de 5 de junio de Asistencia Social de la Comunidad Valenciana (art. 4.6); Ley 1/996 de 14 de mayo de Salud Mental de Cantabria (art. 11); Ley 8/1997 de 26 junio de Sanidad del País Vasco (art. 13); Ley 4/2005 de 17 junio de Salud Pública de la Comunidad Valenciana (art. 31); Ley 18/1998 de 25 junio de Drogodependencias del País Vasco (art. 38); Ley 5/2003 de 3 abril de Personas Mayores de Castilla y León; Ley 1/1993 de 6 abril de Sanidad de Castilla y León; Ley 1/2006 de 28 febrero de Protección de Menores de La Rioja (art. 88); Ley 11/1984 de 15 de octubre de Salud Escolar de Asturias (art. 48); Ley 2/1996 de 8 de mayo de Drogas de Galicia (art. 33); Ley 5/2002 de 27 junio de Drogodependencias y otros trastornos adictivos, de la Comunidad de Madrid (art. 47.1); Ley 9/1987 de 11 febrero de Acción Social de Islas Baleares (art. 5); Ley 5/1997 de 6 de octubre de Drogodependencias de Cantabria (art. 18.f); Ley 3/1994 de 29 marzo de Drogodependencias de Castilla y León (art. 18 f).
}

${ }^{34}$ En estos casos, la invocación a las "disponibilidades presupuestarias" sí se conecta claramente con el alcance de los beneficios formulados en principio como derechos subjetivos de tal modo que son susceptibles de vaciar de sentido estas formulaciones. Así, p. ej., Ley 7/2003 de 9 diciembre de Sanidad de Galicia (art. 133); Ley 7/2002 de 10 diciembre de Sanidad de Cantabria (arts. 28 y 43); Ley 3/1994 de 29 marzo de Drogodependientes de Castilla y León, Ley 2/2002 de 17 abril de la Rioja (art. 16 y Dispos. Adic. $1^{\text {a }}$ ); Ley Foral 10/1990 de 23 noviembre de Salud de Navarra (art. 5.16); Ley 24/2001 de 20 de abril de Prestaciones de Inserción Social de La Rioja (arts. 5.2 y 48.2); Ley 8/2003 de 8 abril de Salud de Castilla y León y Ley 6/1999 de 7 julio de Atención y Protección de las Personas Mayores en Andalucía (art. 23.c).

35 Así, la Ley 17/1998 de 25 junio del Voluntariado del País Vasco (art. 12); Ley 11/2002 de 2 diciembre de Protección de Consumidores y Usuarios de Asturias ( art. 14 e); Ley 3/2997 de 21 marzo de Juventud de Aragón (art. 62); Ley 2/2003 de 30 enero de Vivienda de Canarias; Ley 18/2007 de 28 diciembre del Derecho a la Vivienda de Cataluña (art. 43. 6) y Ley 9/1992 de 7 octubre de Voluntariado Social de Aragón (art. 13). 
Finalmente cabe añadir la observación de que estas cláusulas condicionantes de tipo económico tienen desigual presencia en la legislación autonómica, estando ausentes en las de algunas Comunidades Autónomas, siendo por contra muy frecuentes en otras ${ }^{36}$.

A los efectos aquí pretendidos no es preciso afinar más en los detalles ni descender al terreno del comportamiento real de estos derechos pues queda suficientemente descrita tanto la magnitud de la implantación de la materia social en el ámbito autonómico, como acreditada la muy notable presencia de la figura del derecho subjetivo como instrumento garantizador, realidades éstas que no pueden ser ignoradas a la hora de valorar el hecho de la inserción de los derechos sociales en los nuevos Estatutos.

\section{LA RECEPCIÓN DE LOS DERECHOS SOCIALES EN LOS ESTA- TUTOS DE AUTONOMÍA}

Hablamos de "recepción" en los Estatutos porque, dada la labor legislativa realizada por las Comunidades Autónomas en este campo, según venimos de ver, esa recepción se nos ofrece como un continuum lógico ${ }^{37}$, por más que estas flamantes tablas de derechos sociales contribuyan en gran medida a forjar ese llamado "mito del Estatuto-Constitución"38, o que tengan también que

\footnotetext{
36 Además de las que han sido citadas en las notas precedentes, es paradigmática al respecto la legislación del País Vasco donde la Cláusula "en función de los recursos disponibles" está muy presente. Así, Leyes del País Vasco; 1/1993 de 19 febrero de la Escuela Pública Vasca, 20/1997 de 4 diciembre de Minusválidos; 6/2003 de 22 diciembre, Estatuto de las Personas Consumidoras y Usuarios; 3/2005 de 18 febrero, de Protección de la Infancia y Adolescencia. Un ejemplo de norma plagada de cautelas de este tipo es la Ley 11/1994 de 26 julio de Sanidad de Canarias (arts. 6, $7,9,96 \ldots)$.

${ }^{37}$ En este sentido hay que compartir la opinión de EXPÓSITO, E. sobre la aparente originalidad de los derechos que figuran en los nuevos Estatutos, dada la incorporación de contenidos y derechos -p. ej. salud-que el legislador ordinario ya había regulado: "El Estatuto lo único que hace es recibirlos, dotándolos de un rango normativo más elevado", "La regulación de los derechos en los nuevos Estatutos de Autonomía" en Revista d'Estudis Autonòmics i Federals, núm. 5, 2007, págs. 189 y ss.

38 Vid. MUÑOZ MACHADO, S., "El mito del Estado-Constitución" en La reforma del Estado Autonómico (dir. L. Ortega Álvarez), CEPC, Madrid, 2005, págs. 65-84. Por su parte, BALAGUER CALLEJÓN, M. L. hace relación de otras causas en "Reformas estatutarias y reconocimiento de derechos", Revista General de Derecho Constitucional, núm. 3, Iustel, 2007, págs. 6 y 7.
} 
ver con esa idea tan aireada de que se ha pasado de Estatutos que sólo hablaban de instituciones, a Estatutos que se preocupan "de la gente" 39 . Pero ante todo, esa obra legislativa como antecedente legitimador está ahí y constituye un dato insoslayable como causa inmediata del despliegue sustantivo que ofrecen los nuevos Estatutos.

Es un hecho que los Estatutos originarios también declaraban derechos, deberes y, desde luego, proclamaciones de difícil clasificación jurídica ${ }^{40}$. Pero existen diferencias fundamentales entre estos antiguos enunciados y las Cartas incluidas en los nuevos Estatutos; pueden resumirse en dos: en lo formal, el carácter aislado de aquéllos frente a la sistematicidad de los nuevos; en lo sustancial, la debilidad normativa de aquellos preceptos, salvo los estrictamente apegados a los derechos fundamentales ${ }^{41}$.

Expondremos seguidamente una impronta de las tablas incluidas en los nuevos Estatutos, principalmente en lo que interesa al presente estudio, que no es -valga recordarlo- el régimen mismo de los asuntos sociales, sino el valor de las normas que los regulan ${ }^{42}$.

39 Vid. sobre el particular FERRERES COMELLA, V., "Derechos, deberes y principios en el Nuevo Estatuto de Autonomía de Cataluña" en obra colectiva del mismo título, CEPC, Madrid, 2006, pág. 10 .

${ }^{40}$ MUÑOZ MACHADO, S. ya detectó tempranamente la existencia de normas de carácter no estatutario recogidas en los Estatutos; así regulaciones per saltum, normas reproductoras de derechos fundamentales, mandatos dirigidos a la Administración estatal, normas que expresan la decisión de participar en órganos estatales o que prevén el régimen de las transferencias. Derecho Público de las Comunidades Autónomas, $2^{\circ}$ edic., Iustel, Madrid, 2007, pág. 372.

${ }^{41}$ Sobre la reiteración de derechos fundamentales en los Estatutos originarios, vid. SÁNCHEZ FÉRRIZ, R., "Derechos y libertades públicas en los Estatutos de Autonomía: especial referencia al de la Comunidad Valenciana" en Revista Valenciana d'Estudis Autonòmics, núm. 4, 1986.

42 Para un estudio más detallado de las propias materias han de verse los comentarios referidos a los nuevos Estatutos en general o los que versan sobre concretos Estatutos de Autonomía; así ORTEGA ÁLVAREZ, L., "Los derechos ciudadanos en los nuevos Estatutos de Autonomía" en Estado compuesto y derechos de los ciudadanos. Institut d'Estudis Autonòmics, Barcelona 2007, págs. 68 y ss.; APARICIO WILHELMI, M. y PISARELLO, G., "El reconocimiento de derechos, deberes y principios en los Estatutos de Autonomía; ¿hacia una comprensión multinivel o en red de la protección de los derechos?" en El Clip, núm. 42, 2007, págs. 12 y 13; EXPÓSITO, E., La regulación de los derechos..., cit. pág. 65; CATALÀ I BAS, A. H., "La inclusión de una carta de derechos en los Estatutos de Autonomía" en Revista Española de la Función Consultiva, núm. 4, 2005; del mismo autor, "Estatuto valenciano y construcción del Estado social" en Modelo de Estado y Reforma de los Estatutos, 
Destaquemos lo realmente esencial. Primeramente es obligado resaltar las que pudieran llamarse cláusulas "autolimitativas" de los recientes Estatutos y que son tres: a) los enunciados de esas tablas sólo vinculan a los poderes públicos autonómicos ${ }^{43}$, b) no alteran el régimen de las competencias establecidas; c) dejan a salvo los derechos constitucionales y demás asumidos en Tratados e instrumentos del ámbito internacional. Estas limitaciones quedan condensadas en la fórmula del artículo 37.4 del Estatuto de Cataluña, que luego fue plasmada en los Estatutos posteriores ${ }^{44}$.

obra que comprende comentarios diversos a los Estatutos o Proyectos de la Comunidad Valenciana, Andalucía, Galicia, Canarias, País Vasco. Fundación Prof. Broseta. Valencia, 2007; FERRERES COMELLA, V., en Derechos, deberes y principios.., cit.; APARICIO, M. A., Derechos y principios rectores en los Estatutos de Autonomía, Atelier, Barcelona, 2008; MARTÍN CUBAS, J., "La reforma del Estatuto de la Comunidad Valenciana", en Revista Cortes Generales, núm. 66, 2005; TUR AUSINA, R., "La introducción de un catálogo de derechos en el nuevo Estatuto de Autonomía de la Comunitat valenciana", en Un Estatuto para el siglo XXI, vol I, Revista valenciana d'Estudis autonòmics, núms. 47/48, 2005, págs. 180 y ss.; CÁMARA VILLAR, G. y BALAGUER CALLEJON, F. (coords.): Derechos, Deberes y Principios Rectores en el nuevo Estatuto de Autonomía para Andalucía. Perspectiva comparada, edit. Factoría de Ideas, Centro de Estudios Andaluces, edición digital en la web de dicho Centro. AGUDO ZAMORA, M. J., "Derechos sociales y políticas públicas en la reforma del Estatuto de Autonomía para Andalucía" en Nuevas políticas públicas. Anuario multidisciplinar para la modernización de las Administraciones Públicas, núm. 2 dedicado a los Derechos Sociales; del mismo autor sus comentarios a los "Derechos sociales, deberes y políticas públicas" en Comentarios al Estatuto de Autonomía de Andalucia (dir. S. Muñoz Machado y M. Rebollo Puig), Thomson-Civitas, Madrid, 2008. Comentario al Estatuto de Autonomía de la Comunidad Valenciana (dir. J. M. Baño León), Thomson/Civitas. La reforma de los Estatutos de Autonomía (ob. col.), Revista Jurídica de Castilla y León, Valladolid, 2003.

${ }^{43}$ Es absolutamente expresiva del alcance de esta cláusula la modificación que sufrió el artículo 37.1 Estatuto catalán a su paso por las Cortes Generales. El texto propuesto decía: "Los derechos reconocidos por los Capítulos I, II y III del presente Título vinculan a todos los poderes públicos en Cataluña...", siendo sustituida la preposición en por $d e$, que es como figura en el texto vigente. La sola excepción es la relativa a los derechos previstos en los arts. 32 y 33 en materia de lengua que también vinculan a la Administración General del Estado. Vid. FERRERES COMELLA, V., "Derechos, deberes y principios..." en Derechos, deberes y principios... cit., pág. 22, CAAMAÑO DOMÍNGUEZ, F. M., "Sí, pueden: declaraciones de derechos y Estatutos de Autonomía" en Revista Española de Derecho Constitucional, núm. 79, 2007, pág. 34.

${ }^{44} \mathrm{El}$ texto del artículo 37.4 fue añadido al proyecto de Estatuto catalán por la Comisión Constitucional del Congreso y se inspira en el artículo II-112.2 del Proyecto de Tratado por el que se establece una Constitución para Europa. Así lo señala BIGLINO CAMPOS, P., "Los espejismos de la tabla de derechos" en Derechos, deberes y principios en el nuevo Estatuto de Autonomía de Cataluña, cit. pág. 59. Vid. asimismo CARRILLO LÓPEZ, M., "Los derechos, un contenido constitucional de los Estatutos de Autonomía” en Revista Española de Derecho Constitucional, núm. 80, 2007, pág. 67. Los Estatutos que ofrecen una fórmula idéntica son los de Andalucía (art. 13), Islas Baleares (art. 13.3), Aragón (art. 6.3), Castilla y León (art. 8.3). El texto del proyecto de Estatuto de Castilla La Mancha contiene una fórmula (art. 6.4) que recoge dicha cláusula aunque sólo en parte. 
"Los derechos y principios del presente título no supondrán una alteración del régimen de distribución de competencias, ni la creación de títulos competenciales nuevos o la modificación de los ya existentes. Ninguna de las disposiciones de este Título puede ser desarrollada, aplicada o interpretada de forma que reduzca o limite los derechos fundamentales reconocidos por la Constitución y por los tratados y convenios internacionales ratificados por España”.

A la vista de dicha fórmula, con la que el Estado ha realizado buena parte de su función controladora sobre los Estatutos, bien puede concluirse que la inserción de las Cartas en los Estatutos, si bien es un hecho relevante, no es algo que conmueva pilares básicos del sistema, si se comparte la idea -la legislación autonómica más arriba analizada da sobrado pie para compartirla- de que esas tablas de derechos no plantean un problema de desigualdad entre territorios contraria a la Constitución, punto éste que será considerado más adelante. Por otra parte, hay que señalar que, en buena lógica, una cláusula como la descrita -que en puridad sería innecesaria- debe disipar cualquier duda acerca del marco competencial en el que han de operar las Cartas de Derechos, lo que hace aún menos entendible la razón por la que la STC 247/2007 rebaja los derechos estatutarios a la condición de principios rectores o mandatos al legislador, como veremos, solución ésta con la que el TC quizás haya querido extirpar de raíz toda posibilidad de incursión extraña en el campo de las competencias estatales, máxime si aquélla proviene de Estatutos de Autonomía. Puede ser significativo el dato de que esa degradación de los derechos estatutarios la haya realizado la STC 247/2007 en relación con un Estatuto, el valenciano, que no contiene la cláusula a la que nos hemos referido.

Sentado lo anterior, las características esenciales de los nuevos Estatutos vistos en su conjunto son las siguientes:

a) La organización de la materia.- La heterogeneidad de los recientes Estatutos ya se aprecia en el modo de ordenar esa parte dogmática tan vinculada a la materia social. Aun siendo prácticamente coetáneos puede hablarse de Estatutos que ofrecen una excelente sistemática y otros muy deficientes al respecto. Es ocioso advertir que no hablamos de una cuestión meramente estética sino de gran repercusión sobre el valor mismo de lo que esas tablas contienen. Puede decirse que un Estatuto está bien "organizado" en tal sentido cuando los enunciados referidos a los derechos, deberes y principios están debidamente separados según su naturaleza, cuentan con un precepto que explicita el valor de cada categoría y una cláusula de cierre relativa a las garantías. En suma, si el Estatuto presenta la factura del Título I CE con unas reglas finales como las 
de su artículo 53, habrá categorizado bien sus contenidos y ya no dejará muchas dudas acerca, por ejemplo, de cuándo estamos ante un derecho subjetivo y cuándo ante un principio rector, cuestión ésta ciertamente decisiva.

Con toda resolución puede afirmarse que es modélico en este aspecto el Estatuto de Castilla y León ${ }^{45}$ y que también ofrecen una buena sistemática los de Cataluña y Andalucía pues, amén de clasificar debidamente las materias en sendos capítulos, añaden un último apartado relativo a las garantías; lo que no hace el Estatuto de Aragón ya que aunque distingue perfectamente entre derechos, deberes y principios rectores, carece en cambio de la pieza final expresiva del respectivo alcance jurídico de estas declaraciones. En todo caso hay que resaltar que estos Estatutos expresan con claridad meridiana cuándo la voluntad de la norma es la de establecer derechos o proclamar principios. También ofrecen los de Cataluña y Castilla y León algo tan plausible como la fusión en un solo capítulo de los derechos civiles y los derechos sociales, colocándolos así en un mismo plano y borrando su diferenciación histórica. El Estatuto de Andalucía va incluso más allá, pues el rótulo de su Título I sólo habla de "Derechos Sociales", por contraposición a los "Principios rectores de las políticas públicas" (Cap. III). Sin embargo, desde este punto de vista de la organización de las materias no puede decirse lo mismo del Estatuto valenciano ${ }^{46}$, el de Islas Baleares ${ }^{47}$ o el proyecto estatutario de Castilla-La Mancha ${ }^{48}$.

45 Su Título I está subdividido en cinco capítulos cada uno de los cuales queda dedicado a una categoría de asuntos perfectamente clasificados (Disposiciones Generales, derechos, deberes, principios rectores y garantías). Su Capítulo II, relativo a los derechos, es muy clarificador; no deja duda alguna de que proclama derechos ("tienen derecho" es su expresión típica) y contiene un catálogo bien depurado de derechos sociales (art. 13). Ello no obsta a que en algunos casos haya una remisión a la ley ("en los términos establecidos en las leyes").

46 Ciertamente, su nuevo Título II es un tanto caótico, mezclándose en él derechos y principios rectores hasta el punto de que concurren a veces en un mismo artículo; además carece de precepto ordenador del conjunto y del relativo a la justiciabilidad. No obstante, ello no impide apreciar el impulso que el Estatuto pretende dar a los derechos sociales, como resulta de su artículo 10.1 y 4 .

47 También ofrece este Estatuto una deficiente ordenación, pues aunque las materias están separadas en artículos (no en Capítulos), hay en ellos un evidente desorden; vid. p. ej. la lista incompleta de derechos sociales de su artículo 16, en relación con los artículos 19, 21, 25, 27. Pero lo peor es que ese abigarrado conjunto de materias carece de una cláusula de cierre que estableciera los niveles de protección y evitara esa apariencia de flatus vocis que ofrece el Estatuto en este ámbito.

48 Construye una dudosa categoría - "derechos de las personas"- donde agrupa los derechos que no son económicos y sociales (pero paradójicamente incluye los derechos de los mayores, me- 
Algunos Estatutos, incluso los que ofrecen una mejor sistemática, presentan una peculiaridad cuya bondad se nos antoja dudosa, cual es la duplicidad deliberada de muchas materias, como derecho y como principio rector. Así lo hace con profusión el Estatuto de Cataluña y en alguna menor medida los de Andalucía y Comunidad Valenciana ${ }^{49}$. No contribuyen estas duplicaciones a depurar las categorías jurídicas, ni resultan necesarias, razón por la que no merecen aplauso desde el ángulo del Derecho, pero no permiten argumentar ambigüedad que desdibuje la nitidez con la que los Estatutos, al menos los dos primeros mencionados, configuran los derechos subjetivos verdaderos. En todo caso, es mejor el criterio que brindan los Estatutos de Castilla y León y de Aragón en los que se aprecia mucha pulcritud en la distinción entre derechos y principios, no incurriendo en solapamiento alguno.

b) La distinción entre derechos subjetivos y principios rectores. - Las tablas de los seis Estatutos de la última etapa, más la del proyecto del de Castilla-La Mancha, contienen en su conjunto más de 400 enunciados, de los que más de la mitad se formulan como derechos subjetivos y el resto como principios rectores. Hay que insistir en esta fundamental distinción. Ya ha quedado dicho que pese a las duplicaciones que se dan en los Estatutos de Cataluña y de Andalucía la distinción entre derechos y principios no deja la menor duda, resultando palmario que el estatuyente sabía perfectamente lo que hacía ${ }^{50}$. Con mayor o menor fortuna, otros Estatutos dan acogida a ambas categorías con lo cual secundan también el esquema constitucional. Una excepción notable en este panel es el Estatuto de Castilla-La Mancha, aún en tramitación, ya que únicamente proclama derechos, no contiene principios rectores; o, dicho de otro modo, todos los principios rectores de la Constitución son convertidos en derechos ${ }^{51}$. Desde el punto de vista formal nada habría que objetar pues el es-

nores, jóvenes, mujeres, discapacitados, desfavorecidos, minorías...). Además incluye entre tales derechos de la persona el principio de buena administración, acceso a archivos o registros, datos personales... En fin, creemos que no existen esos "derechos de la persona" como distintos de los derechos sociales y que la agrupación que se hace en el Capítulo I es artificiosa.

${ }^{49}$ En el Estatuto de Cataluña las duplicaciones pasan de la docena; en el de Andalucía no llegan a la decena. En el de la Comunidad Valenciana la dualidad se reduce a cuatro o cinco supuestos.

${ }^{50}$ Resulta terminante al respecto el artículo 12 del Estatuto de Andalucía al distinguir entre "titulares de derechos" y "destinatarios de políticas públicas". La diferencia terminológica es bien elocuente.

${ }^{51}$ En realidad, el Estatuto no establece una sola categoría -"Derechos"- como resultado de esa conversión, sino que mantiene la dualidad "Derechos" y "principios rectores convertidos en derechos" (art. 20) lo cual viene a ser una especie de alarde vano, sin justificación desde el punto de vista técnico. 
tatuyente es muy libre de no incluir en el Estatuto principio rector alguno, pero es claro que una inflación de derechos por conversión masiva de principios rectores, aparte del riesgo de caer en la utopía, puede elevar peligrosamente el nivel de rigidez del Estatuto, convertido así en una especie de programa político cerrado y condicionante de todos los recursos disponibles.

c) Las garantías. - Las cláusulas de cierre tienen la virtud de fijar el alcance jurídico de los tipos de normas comprendidas en estas Cartas. Del conjunto de los Estatutos puede extraerse como conclusión general que éstos crean verdaderos derechos subjetivos, no sólo por la claridad con la que expresan esa voluntad sino por las garantías que anudan a esas declaraciones. Es terminante en este sentido el Estatuto de Cataluña con su serie de instrumentos garantizadores de los derechos contemplados en su Título ${ }^{52}$; y no menos alcance garantizador tiene el Estatuto de Andalucía cuyos derechos "vinculan a los poderes públicos andaluces" ${ }^{\prime 3}$, siendo residenciables ante la jurisdicción correspondiente los actos de los poderes públicos de la Comunidad que vulneren los derechos definidos por el Estatuto (art. 39). En un nivel análogo se encuentra el Estatuto de Castilla y León cuyos derechos "son exigibles en sede judicial bajo las condiciones legalmente establecidas" (art. 17.1) y lo mismo cabe decir del Estatuto de Castilla-La Mancha (art. 21.4), éste con la peculiaridad de que la exigibilidad ante los Tribunales se sobredimensiona por razón de que todo lo que establece son derechos, y con el añadido de que "Los presupuestos de Castilla-La Mancha contendrán las partidas presupuestarias suficientes referidas al sostén financiero de los derechos contemplado en este Título" (art. 21.1). En cambio, muy diferente es el tratamiento que las garantías reciben en los Estatutos de Islas Baleares y de la Comunidad Valenciana, claramente deficitarios en este aspecto. Paradójicamente las circunstancias han

${ }^{52}$ Arts. 37 y 38 y concordantes del Estatuto. En síntesis, se trata de la vinculación directa de los derechos reconocidos por los Capítulos I, II y III a todos los poderes públicos de Cataluña, derechos que, además, "deben interpretarse y aplicarse en el sentido más favorable para su plena efectividad" (art. 37.1); reserva de ley para su regulación esencial (art. 37.3); tutela -dictamen vinculante- por el Consejo de Garantías Estatutarias (art. 38.1); recurso contra los actos que vulneren los derechos reconocidos por los capítulos mencionados ante el TSJ de Cataluña (art 38.2); defensa por el Sindic de Greuges (art. 78).

53 Así lo proclama el artículo 38, añadiendo que "El Parlamento aprobará las correspondientes leyes de desarrollo, que respetarán, en todo caso, el contenido de los mismos establecido por el Estatuto, y determinarán las prestaciones y servicios vinculados, en su caso, al ejercicio de estos derechos". 
querido que el debate sobre la posibilidad de que los Estatutos establezcan derechos haya girado en torno al artículo 17.1 del Estatuto valenciano ${ }^{54}$, especialmente vulnerable en estos aspectos. Cabe preguntarse si la doctrina de la STC 247/2007 hubiera sido la misma de haberse enfrentado el Tribunal la primera vez a un Estatuto provisto de preceptos categóricos como los anteriormente reseñados.

En cuanto a los principios rectores, el tratamiento que ofrecen los Estatutos corre parejo con la desigualdad ya relatada. Así, en los Estatutos mejor estructurados, tales principios presentan las características que les son propias, quedando descuidados estos extremos en los Estatutos que carecen de lo que hemos denominado "cláusulas de cierre" 55 .

Sobre el control judicial, cuestión de importancia suma, a lo más que llegan los Estatutos es a invocar la competencia de la "jurisdicción correspondiente" o a residenciar ante el Tribunal Superior de Justicia respectivo los "actos" de los poderes públicos contrarios a los derechos definidos por el Estatu-

${ }^{54}$ Aunque el artículo 17.1 del Estatuto valenciano haya sido la causa motivadora de la STC $247 / 2007$, lo que interesa aquí de ésta son sus pronunciamientos generales. Para un análisis del tratamiento concreto dado por la Sentencia a dicho precepto puede verse el excelente estudio de GARRORENA MORALES, A., en La constitucionalidad de los nuevos Estatutos en materia de aguas, Fundación IEA, Murcia, 2008, pág. 44 y ss. Sobre los preceptos referentes a las aguas en los nuevos Estatutos de Autonomía, puede verse LÓPEZ MENUDO, F., "Agua y Territorio" en Informe Comunidades Autónomas 2007, IDP, Barcelona, 2008, pág. 46-82.

${ }^{55}$ Valga citar como ejemplo de los primeros el Estatuto de Cataluña con su prolija lista de principios rectores, algunos de los cuales traen causa de los del texto constitucional, otros son de pura creación estatutaria y un tercer grupo, bastante numeroso, versa sobre temas ajenos a los derechos sociales. Es clave su artículo 39: "Son exigibles ante la jurisdicción, de acuerdo con lo que determinan las leyes y las demás disposiciones que los desarrollan", fórmula parecida pero no idéntica a la del artículo 53.3 CE ("sólo podrán ser alegados ante la Jurisdicción ordinaria de acuerdo con lo que dispongan las leyes que los desarrollen") que puede dar pie a la interpretación de que el Estatuto supera a la Constitución en cuanto a la voluntad de tutelar judicialmente estos principios. Semejante redacción ofrece el artículo 40 del Estatuto de Andalucía (aptdo. 1) en cuyo apartado 2 ordena "el impulso de la legislación pertinente, la garantía de una financiación suficiente y la eficacia y eficiencia de las actuaciones administrativas". Por su parte, digno de mencionar es el Estatuto de Castilla y León por la gran cantidad de principios rectores que crea, distintos de los del Cap. III del Tít. I de la CE, principios estos que el Estatuto no repite. Por lo demás, utiliza la fórmula de los Estatutos catalán y andaluz ("son exigibles ante la jurisdicción..."), artículo 17.3, expresión que al menos literalmente no es muy distinta a la que emplea para los genuinos derechos: "Son exigibles en sede judicial bajo las condiciones legalmente establecidas" (art. 17.1). 
to. Precisamente, la incorporación de estos derechos y principios en los nuevos Estatutos trae consigo la duda de si pueden plantearse ante el Tribunal Constitucional recursos contra leyes autonómicas que contraríen lo estatutariamente dispuesto -no necesariamente en el ámbito de las competencias-, duda razonable ${ }^{56}$ que la propia STC $247 / 2007$ ha querido disipar expresamente, como oportunamente ha señalado REBOLLO PUIG ${ }^{57}$, al declarar en su Fto. Jur. 15 que:

“... tales prescripciones estatutarias, como todas las otras contenidas en los Estatutos, habrán de ser tomadas en consideración por este Tribunal Constitucional cuando controle la adecuación de las normas autonómicas al correspondiente Estatuto."

Ello supone equiparar la antiestatutoriedad a la inconstitucionalidad, cualquiera que sea el tipo de precepto estatutario conculcado por la ley.

d) Remisiones estatutarias a futuras Cartas de Derechos sociales.- Concretamente los Estatutos de Cataluña, Comunidad Valenciana e Islas Baleares encomiendan a sus respectivos parlamentos la aprobación de una Carta "de derechos y deberes" o de "derechos sociales". No obstante, existen diferencias entre ellos pues las dos últimas hacen una mera remisión a la Ley en tanto que, en el caso de Cataluña, la Carta viene a ser un elemento desgajado del Estatuto que goza de su misma fuerza vinculante ${ }^{58}$, lo cual no deja de suscitar problemas no sólo de índole formal, sino de fondo, cuyo desarrollo en detalle no es aquí necesario ${ }^{59}$.

${ }^{56}$ MUÑOZ MACHADO, S. incluso ha visto en ello "uno de los defectos más serios que plantea el sistema concentrado de control de la constitucionalidad de las leyes". Tratado de Derecho Administrativo y Derecho Público General, II, Iustel, 2006, pág. 705.

57 Comentarios al Estatuto de Andalucía (dir. Muñoz Machado y Rebollo Puig), cit. pág. 141-142 (nota 45), donde el autor plantea cumplidamente la cuestión, incluyendo la opinión de algunos autores que no han visto nunca problema en afirmar que las leyes contrarias al Estatuto son nulas por inconstitucionales y así deben ser declaradas por el TC.

${ }^{58}$ Art. 37.2: "El Parlamento debe aprobar por ley la Carta de los Derechos y deberes de los ciudadanos de Cataluña. Las disposiciones del presente artículo relativas a los derechos reconocidos por los Capítulos I, II y III del presente Título deben realizarse por Ley del Parlamento".

${ }^{59}$ Baste dejar apuntado cómo desde la perspectiva formal no se explica que tras un Estatuto tan minucioso y prolijo como el catalán donde parece no haber quedado suelto nada de lo que ocurre o pueda ocurrir, haya de dictarse un nuevo texto sobrepuesto al Estatuto dotado de la ri- 
e) Los contenidos. Breve referencia.- También los contenidos estatutarios están presididos por la más pura heterogeneidad. Pese al reducido número de Estatutos considerados no es posible encontrar ningún hilo conductor común.

- Así, en cuanto a los derechos sociales que son a su vez derechos fundamentales de la Constitución o especificaciones de éstos, son particularmente densos los Estatutos de Cataluña, Islas Baleares y Andalucía, mientras que ofrecen menor contenido de este tipo los de Comunidad Valenciana, Aragón ${ }^{60}$ y Castilla y León $^{61}$. Por lo que respecta al principio de igualdad la diversidad es absoluta. Pueden contarse en conjunto hasta una decena de especificaciones de la igualdad (no discriminación por razón de sexo, o de orientación sexual, o por la condición de inmigrante, lucha contra el sexismo, derecho a la diversidad cultural, religiosa y lingüística, etc.). Pues bien, no todos los Estatutos contemplan estas especificaciones, y lo más llamativo es que en unos aparecen formuladas como derechos y en otros como principios rectores. Está presente este valor de la igualdad con especial intensidad en los Estatutos de Cataluña, Andalucía e Islas Baleares.

- La misma disparidad presentan las previsiones estatutarias relacionadas con la voluntad anticipada y muerte digna que aparecen como derechos subjetivos en la mayoría de los Estatutos (salvo el de la Comunidad Valenciana y Castilla y León). También está presente en la mayoría de ellos el derecho a no sufrir tratos inhumanos o degradantes, pero en unos casos como tales derechos y en otros como principios rectores.

gidez que es propia de estas leyes catalanas de Desarrollo Básico del Estatuto (art. 62.2). Vid. la crítica al respecto de FERRERES COMELLA, V., "Derechos, deberes y principios..." en Derechos, deberes...cit., pág. 34. Por otra parte, el problema de fondo deriva del hecho de que se crea una suerte de norma diferida, del mismo valor material que el Estatuto, capaz de vincular al propio legislador y de congelar opciones políticas futuras, con una legitimidad indudablemente menor que la que asiste al estatuyente cuando hace lo propio. No creemos que sea lo mismo petrificar de tal modo una determinada solución en el "momento estatuyente", que hacerlo en cualquier otro momento tan pronto exista una mayoría parlamentaria suficiente.

${ }^{60}$ Ciertamente, es discreta su inmisión en el campo de los derechos fundamentales, salvo en lo que atañe a los derechos de participación (art. $23 \mathrm{CE}$ ) y el derecho a expresar voluntad anticipada ligado al artículo $15 \mathrm{CE}$. Es singular que las especificaciones de la igualdad (no discriminación, igualdad de mujeres y hombres) estén formuladas no como derechos sino como principios rectores.

61 También este Estatuto incide escasamente sobre los derechos fundamentales de la Constitución, salvo en lo relativo al artículo 23 CE sobre participación en los asuntos públicos, donde el Estatuto sí contiene abundantes especificaciones. Esto y la igualdad entre mujeres y hombres es lo que agota el campo donde el Estatuto se adentra en el Cap. II, Tít. I CE. 
- Especial diversificación ofrece el derecho constitucional a participar en asuntos, funciones y cargos públicos (art. $23 \mathrm{CE}$ ), un nutrido catálogo donde predominan los derechos subjetivos, si bien no pocos de ellos (derecho a una buena administración, de acceso a los documentos, al uso de la lengua, a la protección de datos personales, acceso a los empleos públicos con arreglo al mérito y capacidad, etc.) ya figuran consagrados en otras leyes, señaladamente la Ley 30/1992 de RJAP y PAC. Los Estatutos de Andalucía, Islas Baleares y Castilla y León son los que hacen mayor hincapié en estos derechos.

- Sobre el derecho a la educación (art. $27 \mathrm{CE}$ ), otro derecho fundamental, amén de social, los Estatutos en conjunto contienen una veintena de especificaciones (gratuidad de los libros de texto, derecho de los padres a la educación de sus hijos conforme a sus convicciones, derecho a la formación permanente, acceso a las Universidades en condiciones de igualdad, derecho a la integración de personas con necesidades educativas especiales, etc.). Destaca por su atención al respecto el Estatuto de Andalucía seguido del de Cataluña, siendo por el contrario muy escasa la que ofrecen los Estatutos de Aragón y Castilla y León, y nula el de la Comunidad Valenciana.

- Son genuinos derechos sociales los contemplados como fundamentales en los artículos 28, 35 y 37 de la CE (libertad de sindicación y derecho de huelga; derecho al trabajo; negociación colectiva $)^{62}$, todos los cuales figuran incluso en la Carta de Derechos Fundamentales de la Unión Europea y en la Carta Social Europea. Pues bien, en los Estatutos no aparecen especificaciones y ni siquiera reiteraciones de estos derechos fundamentales sociales.

- La protección de la familia, de los hijos, madres e infancia es el primero de los principios rectores de la Constitución (art. 39), singularmente representativo de la materia social. Los Estatutos concretan estos principios en tres de sus manifestaciones más principales: protección de la familia (mayoritariamente como tal principio rector), derechos de las parejas estables, y protección del menor (mayoritariamente como derecho subjetivo). Llama la atención que estén ausentes en los Estatutos algunos de los enunciados contenidos en la Carta de Derechos Fundamentales de la Unión Europea, tales como la protección a las madres trabajadoras o la prohibición del trabajo infantil; aunque lo que más sorprende es que la protección del menor figure en algunos Estatutos (Co-

\footnotetext{
62 Sobre estos derechos, vid. MONTOYA MELGAR, A., "Valores y derechos sociales en la Constitución española de 1978” en Libro Homenaje al Profesor Roca Juan, págs. 557 y ss.
} 
munidad Valenciana, Baleares, Aragón) sólo como principio rector, cuando la legislación de esas Comunidades ya la tiene establecida como derecho. No es que se trate de algo incompatible pero sí es incongruente.

- En materia de promoción y protección del trabajador (art. 40) es nutrido el catálogo de especificaciones conformado por los Estatutos. Predominan, con diferencia, los principios sobre los derechos, referidos éstos a cuestiones de tono menor por superadas, tales como el derecho de acceso a los servicios de colocación, la formación permanente o la garantía del descanso y vacaciones retribuidas. Llama la atención el hecho de que el postulado del artículo $42 \mathrm{CE}$ (retorno de trabajadores en el extranjero) sólo lo contemplan dos Estatutos (Aragón y Castilla y León) en calidad de principios rectores.

- Como no podía ser de otro modo, los Estatutos dan acogida al contenido del artículo $41 \mathrm{CE}$, relativo a las prestaciones de Seguridad Social, incluida la prestación en situaciones de dependencia y la renta básica de subsistencia. En los Estatutos se configuran todas estas prestaciones como derechos con la excepción del de Islas Baleares donde, curiosamente, aparecen como principios rectores a excepción precisamente de la renta de subsistencia, formulada como derecho. Solución igualmente curiosa la ofrece el Estatuto de Aragón, donde la referida "renta" figura como principio rector, guardando silencio sobre el resto de prestaciones de Seguridad Social.

- En cuando al derecho a la salud (art. $43 \mathrm{CE}$ ) todos los Estatutos sin excepción contemplan como derechos sus diversas especificaciones siendo el de Andalucía el más prolijo al respecto si bien, como contrapunto, es el que más cautelas contiene en cuanto a la inclusión de la cláusula de que el ejercicio-sicde los derechos será "en los términos, condiciones y requisitos" que la ley establezca (art. 22.4), siendo así que algunos de estos derechos serían perfectamente ejercitables sin ese desarrollo (p. ej.. derecho a una segunda opinión médica; a la información sobre los servicios a los que puede accederse...) como resulta de la propia legislación ordinaria de la Comunidad. Paradójicamente, este Estatuto proclama de forma categórica, sin condiciones, la garantía misma de la existencia de un sistema sanitario público (también el Estatuto de Aragón), a diferencia de la postura más "tibia" de los de Cataluña y Baleares -sólo como principio rector-y la ausencia de mención alguna en los de la Comunidad Valenciana, Castilla y León y Castilla-La Mancha.

- Llama la atención que los principios rectores constitucionales de acceso a la cultura y promoción de la ciencia e investigación (art. $44 \mathrm{CE}$ ) vengan sin embargo formulados en los Estatutos como derechos (a excepción del Valenciano) y además sin cláusula de remisión a las leyes de desarrollo, cuando en es- 
ta materia tal desarrollo parece imprescindible, todo lo cual lleva a la sospecha de que se está pasando al terreno de los "derechos-aspiración" más que al de los auténticos derechos subjetivos estatutarios, aunque cierto es que la ausencia de dicha cláusula no impide considerarla implícita.

- El medio ambiente (art. $45 \mathrm{CE}$ ) se formula como derecho en los Estatutos (salvo el de Castilla y León). Hay una concreción del mismo especialmente presente, en dichos Estatutos, igualmente como derecho: el de disfrutar de los recursos naturales situados en el territorio. Aparte de ello son muy numerosas las especificaciones que quedan proclamadas como principios rectores, destacando los catálogos que ofrecen al respecto los Estatutos de Cataluña y Andalucía.

- En aras de la síntesis y por lo que se refiere a los restantes principios rectores de la Constitución puede afirmarse que salvo en materia de "participación de la juventud" (art. 48), predominan los enunciados proclamados como derechos sobre los formulados como principios rectores; así y por este orden los referidos a vivienda (art. 47), consumidores y usuarios (art. 51), minusválidos (art. 49), protección de la tercera edad (art. 50).

- Además de los contenidos referidos, los Estatutos contienen enunciados nuevos en número aproximado al medio centenar, en su gran mayoría formulados como principios rectores, con unas excepciones harto significativas: los enunciados relativos al agua, contemplados en el Estatuto de Aragón y en el ya celebérrimo artículo 17 del valenciano. Conforman un catálogo de principios de lo más variado: desde lo más ampuloso ("defensa y promoción de los derechos sociales", "servicios públicos de calidad", "derecho de los ciudadanos a recibir una información plural y veraz", "defensa de los valores e intereses del pueblo"...) hasta lo que se percibe como medidas operativas concretas e inmediatas ("lucha contra la despoblación", "fomento del voluntariado", "protección a personas dañadas por catástrofes", "incremento de la seguridad vial", "defensa de la lengua catalana", etc.). Destacan sobremanera en la aportación de estos nuevos principios los Estatutos de Castilla y León y de Cataluña, a la vista de los cuales da la impresión de que no queda ya aspecto alguno de la vida social que no haya sido recogido en los Estatutos de Autonomía.

IV. UN EXCURSUS IMPUESTO POR LA STC 247/2007 DE 12 DICIEMBRE: PODER DE LA LEGISLACIÓN AUTONÓMICA PARA PROCLAMAR PRINCIPIOS, DERECHOS Y DEBERES

El recurso de inconstitucionalidad interpuesto por el Gobierno de Aragón contra el artículo 17.1 del Estatuto valenciano, según resulta del relato de 
hechos del Antecedente I de la STC 247/2007 de 12 de diciembre, no cuestiona si las leyes autonómicas pueden crear derechos u obligaciones, sino si esto lo puede hacer un Estatuto. Sin embargo, la Sentencia no se enfrenta de inmediato a tal asunto sino que previamente se enfrasca en el análisis del papel que desempeña al respecto la ley autonómica, de tal modo que ésta constituye el eje sobre el que gira todo el razonamiento sobre las facultades del legislador y sus límites, esfuerzo innecesario a la vista de la ingente labor realizada al respecto por las Comunidades Autónomas en los últimos veinticinco años, creando masivamente derechos y deberes, por lo que el discurso se antoja como una elucubración desfasada, superada por la realidad. Pero el Tribunal ha optado en este caso por recibir la doctrina acuñada en torno a las leyes autonómicas creadoras de derechos, tejer con ella un fondo argumental favorable a sus tesis y extrapolar las conclusiones al plano de los Estatutos, por cierto de forma expeditiva.

\section{La posibilidad de desarrollar y "especificar" derechos fundamentales}

La inmisión de las leyes autonómicas en el ámbito de los derechos fundamentales y entre ellos los de contenido social (salvo en sus aspectos esenciales), más que algo posible es un hecho indiscutible; se encuentra avalado en la práctica por innumerables leyes autonómicas, está palpablemente reflejado en los nuevos Estatutos de Autonomía y cuenta con un apoyo inequívoco de la jurisprudencia constitucional. Ya la temprana Sentencia 25/1981 de 14 de julio (Fto. Jur. 5), declaró que "Los derechos constitucionales no se ven afectados por la estructura federal, regional o autonómica del Estado". Con la Sentencia 37/1981 quedó prontamente establecida la barrera entre lo que compete hacer al Estado en cuanto a la regulación de los derechos fundamentales ("cuando afecte a las condiciones básicas que garanticen la igualdad de todos los españoles en el ejercicio de los derechos y en el cumplimiento de los deberes constitucionales") y lo que pueden hacer las Comunidades Autónomas siempre que cuenten con competencia suficiente ("cuando la norma legal, aunque con incidencia sobre el ejercicio de derechos, no afecte a las condiciones básicas de tal ejercicio"). Esta doctrina, seguida por otra importante STC 173/1998, relativa al derecho de asociación, ha sido cumplidamente estudiada por PEMÁN GAVÍN y por otros autores ${ }^{63}$ a resultas de lo cual se concluye

63 PEMÁN GAVÍN, J. M., Igualdad de los ciudadanos y autonomías territoriales, Civitas, Madrid, 1992, págs. 207-228. VIVER PI-SUNYER, Materias competenciales y Tribunal Constitucional: la delimitación de los ámbitos materiales de las competencias en la jurisprudencia constitucional. Ariel. Barcelona, 
que en el ámbito de los derechos fundamentales pueden darse competencias exclusivas del Estado, competencias compartidas e incluso, como destaca ORTEGA ÁLVAREZ, regulación exclusiva de la Comunidad Autónoma en determinados derechos fundamentales como el de participación política (así, los derechos de participación en las elecciones autonómicas $)^{64}$.

Ciertamente, los espacios abiertos al legislador autonómico son considerables y la fijación de hasta dónde éste puede llegar se sitúa en el marco de las reglas sobre la distribución competencial ${ }^{65}$, (siempre correspondiendo al Estado la regulación de lo esencial). Y en la misma línea, la STC 247/2007 sobre el Estatuto valenciano declara que "nada determina que el régimen jurídico de los derechos constitucionales quede sustraído a las reglas del reparto competencial", de tal modo que es posible que la normativa autonómica incida en la regulación del régimen jurídico de esos derechos (Fto. Jur. 13).

La Sentencia 247/2007 toca esta cuestión cuando aborda el tema del contenido posible de los Estatutos y lo hace no con la claridad deseable, dada la trascendencia del asunto, echando sobre el intérprete una carga que tendría que haber evitado. Veremos todo ello en el siguiente capítulo, precisamente dedicado a los Estatutos.

\section{La posibilidad de crear derechos nuevos (o derivados de principios recto- res constitucionales)}

Aclaremos el sentido del epígrafe por vía negativa: los derechos aquí referidos son ajenos a los derechos fundamentales; por tanto, se trata de los derechos subjetivos ordinarios o típicos de todo ordenamiento jurídico, que son, desde el punto de vista cuantitativo, incomparablemente más numerosos que

1989. LÓPEZ GUERRA, L., "La doctrina del Tribunal Constitucional en relación con el artículo 149.1.1 $1^{\mathrm{a}} \mathrm{CE}$ " en La función del artículo 149.1.1 ${ }^{a}$ CE en el sistema de distribución de competencias, VV. AA., Generalidad de Cataluña, Barcelona, 1992. LUCAS MURILLO, E., "Delimitación de la competencia autonómica para la regulación de los derechos fundamentales" en Revista de Derecho Politico, núm. 46, 1999. ORTEGA ÁLVAREZ, L., "Los derechos ciudadanos..." en Estado compuesto..., cit.

${ }^{64}$ ORTEGA ÁlVAREZ, L., "Los derechos ciudadanos...”, en Estado compuesto... cit., pág. 60-61.

65 Vid. LUCAS VERdú, P. y LUCAS MURILlO DE LA CUEVA, P., "Comentario al artículo 139. Autonomía e igualdad. La posición jurídica de los ciudadanos en el Estado de las Autonomías" en Comentarios a la Constitución española, (dir. Oscar Alzaga), Cortes Generales-EDERSA, pág. 477. 
los derechos fundamentales. A estas alturas, plantear en clave especulativa la posibilidad de que las leyes autonómicas establezcan derechos subjetivos es incluso extravagante a la luz de la realidad que ya hemos descrito en capítulo anterior. Esa realidad es simplemente el fruto de la lógica del sistema: diecisiete parlamentos autonómicos produciendo leyes, distintas políticas presionando sobre ellos, bagajes competenciales más que sobrados para incidir en muchísimos aspectos de la vida social..., la conclusión irrefutable es que sería casi imposible hacer un inventario de los derechos y deberes creados por los ordenamientos autonómicos. Por tanto, lo propio es hablar de límites a ese poder generador de relaciones y situaciones jurídicas, no de posibilidad. A ese poder se ha referido la STC 247/2007 (Fto. Jur. 14) en términos categóricos, como no podía ser de otra forma:

"nuestra Constitución permite que las Asambleas legislativas de las Comunidades Autónomas establezcan sus propias políticas diferenciadas en las materias de su competencia y que, al hacerlo, determinen una diversidad de regímenes jurídicos en cada una de ellas con los efectos consiguientes sobre los ciudadanos de cada territorio autonómico, efectos que podrán producirse a través de los diversos medios, instrumentos o técnicas que son inherentes al ejercicio de la autonomía política (declaraciones programáticas, formulación de derechos subjetivos de los destinatarios de las actuaciones o adopción de medidas concretas, entre otras posibles)".

Sentado lo anterior, hay que insistir en que los derechos a los que aquí nos estamos refiriendo son, efectivamente, los creados ex novo por el legislador autonómico en virtud de su propia voluntad e inventiva o por encontrarse compelido para ello por la legislación básica estatal de un modo más o menos definido. Pero además, han de incluirse en el círculo de estos derechos "nuevos" o no fundamentales, los creados por las Comunidades Autónomas en ejecución de los principios rectores de la política social y económica del Cap. III, Tít. I CE, ya que la Constitución no obliga a convertir necesariamente esos principios en derechos públicos subjetivos. Por esta razón, el establecimiento de un derecho por ley autonómica será un derecho de pura creación suya, aunque traiga causa de un principio rector de la Constitución; un derecho, eso sí, que supone la materialización más acabada de ese postulado constitucional.

Estas leyes autonómicas que crean derechos, deberes y principios, como ordinarias que son, podrán ser derogadas por otras leyes autonómicas posteriores; pero se plantea la cuestión de hasta qué punto ese poder derogatorio es libre si se trata de eliminar o de modificar in peius leyes sociales que ya han marcado un nivel o estándar de prestaciones y, desde luego, cómo reparar los 
derechos adquiridos por los sujetos beneficiarios titulares de derechos subjetivos, temas éstos que tienen relación con los problemas sobre la efectividad de los derechos sociales que abordaremos al final de este discurso.

De otra parte, es perfectamente posible que las leyes autonómicas no sólo establezcan o reconozcan derechos y deberes, sino que proclamen principios, objetivos o directrices con la pretensión de vincular la producción normativa ulterior y la acción administrativa. Esta práctica es bien visible en las leyes de cabecera que regulan las áreas más significativas de la acción social, como vimos supra. Pues bien, hay que decir que al venir formulados tales principios con el rango de la ley, serán vinculantes para las disposiciones reglamentarias y demás actuación administrativa pero no vincularán al propio legislador autonómico. Ahora bien, lógico será que en una situación normal, las eventuales leyes posteriores que pudieran aprobarse se plieguen a los criterios proclamados por la ley institucional o de cabecera, revestida así de una especie de superioridad material como es lo propio de los conjuntos normativos bien organizados. Pero hay que insistir: en el plano de la legislación ordinaria es posible que el legislador actual no se sienta vinculado por los principios o directrices señalados por el legislador anterior y, en consecuencia, adopte soluciones que se aparten de dichos principios o formule otros principios distintos.

\section{Límites al poder normativo de los parlamentos autonómicos}

La STC 247/2007 reduce a la mínima expresión la posibilidad de que los Estatutos proclamen eficazmente derechos y deberes. Ello sólo será posible mediante la pura repetición de derechos fundamentales y, como veremos más abajo, respecto a los derechos subjetivos relacionados con las "instituciones autonómicas propias”; algo realmente insignificante puesto en comparación con el mundo de los derechos subjetivos ordinarios o los vinculados con los derechos fundamentales sustantivos. De esta importante circunstancia resulta que todo el aparato argumental que la Sentencia pone en acción en orden a fijar los límites del poder normativo autonómico tiene muy poco sentido, ya que lo hace mirando a las leyes autonómicas ordinarias, y no es en este plano donde reside el problema que el recurso de inconstitucionalidad planteaba; y cuando esa argumentación sobre los límites la refiere a los Estatutos, ello es más inútil aún pues una vez negada la posibilidad de que éstos establezcan derechos y deberes, huelga hablar de límites a un poder que la propia Sentencia no reconoce.

La doctrina, ante la irrupción de los nuevos Estatutos con sus tablas de derechos, se ha ocupado, como no lo había hecho antes, lógicamente, de seña- 
lar esos límites al poder del Estatuto como fuente generadora de derechos y deberes, pero tras la Sentencia 247/2007 ese esfuerzo se ha vuelto baldío por haber decaído el objeto de estudio: no hay derechos estatutarios, no plantean ya problemas. Sin embargo, no podríamos omitir aquí algo de lo que se ocupa tanto dicha Sentencia (en relación con las leyes ordinarias) y que ha merecido tanta atención doctrinal. Por ello, nos referimos a tales límites aunque con la concisión impuesta por las circunstancias señaladas.

\section{A) Cobertura competencial suficiente.}

En lo que atañe a las leyes autonómicas, la necesidad de contar con la atribución competencial necesaria opera como una condición absoluta ${ }^{66}$. Supuesta la existencia de la competencia oportuna no hay una reserva a favor del Estado para proclamar derechos y ni siquiera ostenta éste el monopolio normativo en relación con los derechos fundamentales. En lo que se refiere a los Estatutos de Autonomía la conclusión debe ser idéntica: los preceptos estatutarios que enuncian principios, derechos y deberes son lícitos si están respaldados por títulos competenciales ya que tales enunciados no son atributivos de competencias. De lo anterior se sigue que la normativa autonómica debe respetar siempre, como señala la STC 247/2007, Fto. Jur. 13, "las determinaciones que pudieran seguirse de las competencias estatales (art. 149.1 CE) ${ }^{67 "}$. Es obligado mencionar la trascendente doctrina de la Sentencia sobre la función delimitadora del reparto competencial que cumplen los Estatutos, -la llamada "desconstitucionalización"- (Fto. Jur. 7) que ha suscitado lógica inquietud y alguna tensión en la doctrina ${ }^{68}$.

66 Sobre el particular y demás precisiones, vid. AGUADO RENEDO, C., El Estatuto de Autonomía y su posición en el ordenamiento jurídico, CEC, Madrid, 1996, pág. 358 y ss.

67 Vid. in extenso sobre este punto, MARTÍNEZ LÓPEZ MUÑIZ, J. L., "Límites constitucionales generales del contenido de las reformas estatutarias" en La reforma de los Estatutos de Autonomí... cit. págs. 109 y ss.

68 Cfr. al respecto FERNÁNDEZ FARRERES, G., ¿¿Hacia una nueva doctrina constitucional del Estado Autonómico? (Comentario a la STC 247/2007 de 12 de diciembre sobre el Estatuto de Autonomía de la Comunidad valenciana), Thomson-Civitas, 2008, pp.. 74 y ss.; y ARAGÓN REYES, M., "A propósito de la crítica de Germán Fernández Farreres a la STC 247/2007”, en REDC, núm. 83, 2008, pág. 149 a 152. GARRORENA MORALES, A., La constitucionalidad de los nuevos Estatutos... cit. pág. 55 y ss. TORNOS MAS, J., "La Sentencia del Tribunal Constitucional 247/2007 y el sistema constitucional de distribución de competencias entre el Estado y las Comunidades Autónomas" en Revista d'Estudis Autonòmics i Federals, núm. 7, octubre 2008, pág. 79 y ss. Por nuestra parte, nos permi- 
B) Respeto al ámbito de las leyes orgánicas reguladoras de los derechos fundamentales.

Hay una reserva constitucional absoluta para declarar derechos fundamentales. Como dice CRUZ VILLALÓN, las libertades están en la Constitución y en ningún otro lugar del ordenamiento constituido; tienen sus propios caracteres, sus propias reglas y sobre ello no deben caber muchas dudas ${ }^{69}$. Y existe también una reserva constitucional absoluta a favor del Estado para $d e-$ sarrollar en sus aspectos esenciales los derechos fundamentales y libertades públicas $^{70}$; por tanto, las leyes autonómicas no pueden usurpar esa competencia ni tampoco pueden hacerlo los Estatutos de Autonomía. El desarrollo de esos

timos repetir lo que en otro lugar hemos dicho al respecto: Es evidente que la doctrina en cuestión, pese a las salvaguardas que contiene en favor de las competencias del Estado lleva ínsito un evidente desequilibrio en el resultado final del sistema: así, de una parte, quedan anticipadas al detalle las competencias autonómicas mediante un Estatuto concienzudamente elaborado para apurar la delimitación hasta sus últimos resquicios; de la parte estatal, un acervo competencial difuso, abocado a tener que acreditarse cada vez y en cada caso en la letra de una Constitución escasa que no fue concebida en su día para dar soporte a esta confrontación tan aquilatada. Es obvio que esa anticipación estatutaria conlleva de hecho un prejuicio muy sólido sobre su primacía, con la consecuencia de que el Estado tenga que actuar siempre a la contra cuando trate de defender lo que estime como suyo. Todo ello viene a demostrar la absoluta necesidad de que se hubiese procedido a reformar la Constitución antes de emprender el proceso de reformas estatutarias, y no precisamente con la finalidad de reprimir aspiraciones autonomistas sino para racionalizar tan magna operación de cambio, adecuando el texto constitucional a las nuevas circunstancias. LÓPEZ MENUDO, F., "Clasificación, principios y consideraciones generales sobre las competencias" en Comentarios al Estatuto de Andalucía (dir. S. Muñoz Machado y M. Rebollo Puig), cit. pág. 338-339.

${ }^{69}$ CRUZ VILLALÓN, P., "Los derechos sociales y el Estatuto de Autonomía" en Estudios sobre el estado social. El estado social y la Comunidad Autónoma de Andalucía", Parlamento de Andalucía-Tecnos, 1993, pág. 99. En el mismo sentido dice Marc CARRILLO que en un Estado único pero de estructura compuesta como el español, la Constitución y sólo ella es el instrumento normativo a tenor del cual se reconocen los derechos fundamentales con efectos constitutivos, "Los derechos, un contenido constitucional...", en Revista Española de Derecho Constitucional, cit., pág. 58.

${ }^{70}$ Se trata del "desarrollo legislativo directo" como expusieron tempranamente SANTAMARÍA PASTOR, J. A., "Las leyes orgánicas; notas en torno a su naturaleza y procedimiento de elaboración" RDP de la UNED, núm. 4, 1979 y BERMEJO VERA, J., "Las fuentes del Derecho de la Constitución española de 1978”, en Estudios sobre la Constitución española de 1978, Pórtico, Zaragoza, 1979. Vid. asimismo AGUADO RENEDO, C., El Estatuto de Autonomía y su posición..., cit., pág. 338. 
derechos y libertades está entregado por la Constitución a la ley orgánica (art. $81.1)^{71}$. Cierto es que los Estatutos también son aprobados mediante ley orgánica, pero no es ésta a la que se refiere el artículo 81.1 cuando habla del "desarrollo de los derechos fundamentales ${ }^{72 "}$. Lo que se acaba de decir es sólo un punto de partida; quedan otros aspectos a despejar muy importantes, dado el intenso vínculo que guardan muchos enunciados estatutarios con derechos fundamentales de la Constitución ${ }^{73}$. Es obligado tratar estas cuestiones más adelante, al hablar concretamente del contenido posible de los Estatutos.

\section{C) Respeto al principio de igualdad $e x$ art. 139.1 CE.}

El recurso del Gobierno aragonés contra el artículo 17.1 del Estatuto valenciano, al invocar la infracción de éste al principio de igualdad, da pie a que la Sentencia se explaye sobre este punto, sacando a relucir la jurisprudencia ya existente en torno al artículo $139.1 \mathrm{CE}$ ("Todos los españoles tienen los mismos derechos y obligaciones en cualquier territorio del Estado") y su relación con las leyes autonómicas que crean desigualdades territoriales, doctrina que le sirve en esta ocasión para enjuiciar dicho precepto del Estatuto.

Como notaron tempranamente ciertos autores, una interpretación apresurada del precepto lo hace difícilmente encajable en el esquema de un Estado compuesto. Los términos de este precepto, como ha señalado PEMÁN GA-

71 Para realzar la centralidad de los derechos fundamentales CRUZ VILLALÓN, P., dice expresivamente que si se incorpora a un Estatuto un derecho fundamental nuevo, entonces habría que incorporarlo automáticamente a todos los Estatutos, pues el artículo 149.1.1 ${ }^{\text {a }} \mathrm{CE}$ contiene una exigencia de igualdad de todos los españoles en esta materia. "Los derechos sociales..." en Estudios sobre el estado social..., cit. pág. 106. Claro es que se trata de un excelente razonamiento utilizando la ficción ya que ni un Estatuto de Autonomía ni todos a la vez podrían jamás consagrar un nuevo derecho fundamental, como se dirá en el texto.

${ }^{72}$ Así, entre otros, AGUADO RENEDO, C., El Estatuto de Autonomía..., cit. pág. 338. DÍEZ-PICAZO GIMÉNEZ, L. M., “¿Pueden los Estatutos de Autonomía declarar derechos, deberes y principios?” en Revista Española de Derecho Constitucional, núm. 78, 2006, pág. 71. Por su parte, BIGLINO CAMPOS, P., "Los espejismos de la tabla..." en Derechos, deberes y principios..., cit., dice con todo acierto que dicho precepto contiene un procedimiento especial a favor de las Cortes Generales, único órgano legitimado para regular los elementos esenciales de la definición del derecho fundamental; y cita jurisprudencia constitucional al respecto.

${ }^{73}$ Casi la mitad -43\%- de los derechos subjetivos que se incluyen en los nuevos Estatutos tienen que ver con derechos fundamentales, y una cuarta parte de los principios rectores estatutarios también conectan con el Cap. II del Tít. I de la CE. 
VÍN, son ciertamente oscuros, porque parecen imponer una estricta uniformidad territorial del status jurídico de los españoles en todos sus aspectos ya que no hace matización alguna ${ }^{74}$. Algunos autores achacan a una primera Sentencia del TC -25/1981, de 14 de julio- la adopción de una interpretación uniformista y por tanto reñida con el propio modo de ser del sistema autonómico $^{75}$ pero lo cierto es que fue la Sentencia 37/1981 de 16 de noviembre la que excluyó esa línea interpretativa, afirmando que

"no puede ser entendido en modo alguno como una rigurosa y monolítica uniformidad del ordenamiento de la que resulte que, en igualdad de circunstancias, en cualquier parte del territorio nacional se tienen los mismos derechos y obligaciones".

Sentada la anterior premisa, -que vino a situar el artículo 139.1 en el mismo plano que el artículo 149.1.1 ${ }^{\mathrm{a}}$, es decir, en la orientación de conseguir una cierta homogeneidad, limitando la diversidad jurídica excesiva- ${ }^{76}$ el siguiente paso fue el de abandonar esta tendencia a utilizar el artículo 139.1 como un mecanismo de igualación o nivelación interterritorial y darle una interpretación distinta, acorde con el sentido de su antecedente histórico -art. 17 de la Constitución de 1931- y el artículo 33.1 de la Ley Fundamental de Bonn en el que se inspiró, según el cual "todo alemán tiene en cualquier Land iguales derechos y obligaciones ciudadanos", precepto que, por tanto, nunca se ha en-

${ }^{74}$ Igualdad de los ciudadanos..., cit. págs. 138. Así lo ha advertido un sector doctrinal numeroso, entre otros, DE OTTO, I., "Los derechos fundamentales y la potestad normativa de las Comunidades Autónomas en la Jurisprudencia Constitucional”, RVAP, 10, 1984; BAÑO LEÓN, J. M., Las Autonomías territoriales y el principio de uniformidad de las condiciones de vida, Madrid, 1988, págs. 192-193; CARRO, J. L., "Contenido y alcance de la competencia del Estado definida en el artículo 149.1.1 ${ }^{a}$ de la Constitución” REDL 1, 1981; LUCAS VERDÚ, P. y LUCAS MURILLO DE LA CUEVA, P., "Comentario al artículo 139..." en Comentarios a la Constitución..., cit. págs. 475 y ss.; ÁLVAREZ CONDE, E., “Curso de Derecho Constitucional’, Vol. II, Tecnos, Madrid, 1993, págs. 359-360.

${ }^{75}$ Así, por ejemplo, AGUADO RENEDO, C., El Estatuto de Autonomía..., cit., pág. 342; LUCAS VERDÚ, P. y LUCAS MURILLO DE LA CUEVA, P., "Comentario al artículo 139..." en Comentarios a la Constitución..., cit. pág. 474; BALAGUER CALLEJÓN, M. L., "Reformas estatutarias..." en Revista General de Derecho Constitucional, cit. pág. 4. La verdad es que, a nuestro juicio, una lectura atenta de la Sentencia no permite extraer esa conclusión. No se niega la heterogeneidad del sistema autonómico porque la Sentencia diga que "...la Constitución reserva a la Cortes Generales todo cuanto se refiere al desarrollo de los derechos fundamentales y de las libertades públicas" ¿Es que podría decir otra cosa?

76 PEMÁN GAVÍN, J. M., “Igualdad de los ciudadanos...”, cit. pág. 140. 
tendido como una regla de uniformidad u homogeneidad del Derecho aplicable en todo el territorio federal sino como precepto de equiparación de todos los alemanes respecto a cada Land ${ }^{77}$. Y éste es el sentido por el que se decanta más claramente la STC 173/1998, es decir, el de la proyección del principio de igualdad en el ámbito intracomunitario, en el interior de cada ordenamiento autonómico, solución propuesta en su día por IGNACIO DE OTTO. Tal solución se encuentra tan aceptada por la doctrina que DÍEZ-PICAZO, uno de los autores más contrarios a la inserción de tablas de derechos, deberes y principios en los Estatutos de Autonomía, renuncia expresamente a utilizar el artículo 139.1 CE en defensa de su postura, reconociendo que lo que éste opera es un mandato de igualdad dentro de cada ordenamiento autonómico ${ }^{78}$, lo que habremos de matizar más abajo.

Vemos así que el estado de la cuestión está tan claro en la doctrina como espeso en la prolija argumentación de la STC 247/2007. Ésta se enreda en sus FF.JJ. 13 y 14 en una serie de consideraciones que enturbian más que aclaran la tesis a la que finalmente llega, que es la que acabamos de referir ${ }^{79}$. Así, comienza sustentando una interpretación "moderada" de la igualdad ex art. 139.1 CE, al decir que éste no contempla una uniformidad absoluta sino "un principio de igualdad sustancia ${ }^{80}$ susceptible de modulaciones diferenciadas

\footnotetext{
77 Añade el propio PEMÁN que el precepto enlaza claramente con la privileges and inmunities clause de la Constitución americana y con el artículo 60 de la Constitución suiza, y cita al respecto la explicación de T. MAUNZ: no se trata de una regla de nivelación-esto es, de una regla que obligue a que los alemanes del Land A tengan en su Land los mismos derechos que los alemanes del Land B tienen en el suyo- sino de un precepto de extensión; los derechos y obligaciones que el Land A establece en relación con sus residentes deben reconocerse por dicho Land a los alemanes de B o C. Ibídem, nota 10.
}

78 DÍEZ-PICAZO GIMÉnEZ, L. M., “¿Pueden los Estatutos de Autonomía...?”, en Revista Española de Derecho Constitucional, cit. pág. 64.

${ }^{79}$ En efecto, no se reprime la Sentencia al hablar, a propósito del artículo 139.1 CE de "un sustrato de igualdad en todo el territorio nacional", "contenidos básicos del ordenamiento del conjunto estatal", "elemento unificador", "patrimonio común de los ciudadanos, individual y colectivamente", "constitutivos del ordenamiento jurídico cuya vigencia a todos atañe por igual”... lo que resulta bastante desproporcionado con el alcance que finalmente otorga a dicho precepto. Los vaivenes que va dando la Sentencia y la incoherencia de su conclusión es puesta de relieve por CABELLOS ESPIÉRREZ, M. A., "La relación derechos-Estado Autonómico en la Sentencia sobre el Estatuto valenciano”, Revista d'Estudis Autonòmics i Federals, núm. 7, Octubre 2008, pág. 122 y ss.

${ }^{80}$ Discrepa de esta concepción del artículo 139.1 el magistrado don Vicente CONDE MARTÍN DE HIJAS, al afirmar que la eficacia real de este principio general de la Organización Territorial 
en mayor o menor grado en las Comunidades Autónomas, según el tipo de derecho de que se trate y el reparto competencial en la materia implicada" (Fto. Jur. 13) para concluir -Fto. Jur. 14- que el art. 139.1 CE “... encuentra virtualidad y proyección en el territorio de cada una de las Comunidades Autónomas” (Fto. Jur. 14), uno de los puntos clave de la Sentencia que ésta mantiene cuando lo refiere a los Estatutos ${ }^{81}$ y del que discrepan algunos magistrados de la Sala ${ }^{82}$.

del Estado "se escamotea cuando una idea tan precisa como la que se expresa en los términos 'los mismos derechos' y 'en cualquier parte del Estado', se convierte en unidad sustancial, no uniformidad, y en la consideración aislada de cada parte del territorio, y no en la de su conjunto".

${ }^{81}$ En efecto, cuando la Sentencia, tantas veces citada, aborda -FFJJ 19 y 20 - el enjuiciamiento del artículo 17.1 del Estatuto valenciano y su presunta violación del artículo 139.1 CE -que había sido invocada por la demanda- omite absolutamente cualquier referencia a la igualdad interterritorial y afirma que dicho precepto constitucional no ha sido atacado porque: a) el precepto estatutario tiene el respaldo de la competencia autonómica sobre la materia; b) no colisiona con ningún derecho o principio rector de la Constitución; c) no establece ningún derecho subjetivo y por tanto no vincula la función legislativa del Estado, que podrá ejercerla sin condicionamiento alguno; d) es un precepto concorde con el modelo del Estado social y democrático de derecho. Con estos argumentos, ciertamente periféricos a lo que la demanda aducía contra el Estatuto, la Sentencia despacha lo concerniente a la igualdad $e x$ art. 139.1. CE.

${ }^{82}$ El magistrado don Javier DELGADO BARRIO, en su voto particular destaca la relevancia del papel a cumplir por el principio de igualdad reconocido en el artículo 139.1 CE "que tiene un objeto necesariamente distinto al correspondiente a los artículos 81.1, inciso primero, -derechos fundamentales y libertades públicas- y artículo $149.1 .1^{\mathrm{a}} \mathrm{CE}$-derechos y deberes constitucionales[...] y puesto que el artículo 139.1 CE proclama la igualdad de derechos y el Estatuto es desigualdad quiérese decir que éste no es, evidentemente, cauce adecuado para la proclamación de derechos". El magistrado Sr. RODRÍGUEZ ZAPATA muestra su disconformidad con el tratamiento de que es objeto el artículo 139.1 CE, señalando (aptdo. 10) que "el ejemplo más claro de deconstrucción de un texto constitucional lo ofrece nuestra jurisprudencia tradicional sobre el artículo 139.1 CE que ahora se extiende en el razonamiento de la Sentencia (FFJJ 13 y 14), cuando el mismo precepto debe jugar un papel esencial y distinto al que desempeñó en un sistema en el que los Estatutos de Autonomía carecían de "parte dogmática" o de tablas de derechos estatutarios. El artículo 139.1 CE era hoy capital para la resolución del presente proceso constitucional en un nuevo escenario de Estatutos de Autonomía distintos, tras las reformas de éstos producidas en el tercer período de reformas [pero] la Sentencia, tras prolijas disquisiciones, niega el sentido literal del texto del artículo $139.1 \mathrm{CE}$, para luego demostrar que lo que en realidad debe entenderse que dice es: cada español tendrá los mismos derechos en la Comunidad Autónoma en la que se encuentre en cada momento [...]; era necesario atribuir al artículo 139.1 una dimensión extraautonómica [pues] garantiza, en su dimensión extracomunitaria, un mínimo de igualdad en el goce de los servicios públicos y de los derechos que garantiza un Estado social”. Por su parte, el magistrado don Roberto GARCÍA CALVO, en su voto particular, discrepa del alcance que la Sentencia da al artículo 139.1 "reduciéndolo y apegándolo al 149.1.1ª CE, desconociendo que, amén de competencias del Estado hay funciones del mismo: garante de la unidad, la igualdad y defensor del interés general". 
A la vista de que el artículo 139.1 CE no impide la diversidad interterritorial, GÓMEZ-FERRER MORANT observa, no sin razón, que las declaraciones de derechos también podrían figurar en los Estatutos de Autonomía ${ }^{83}$, algo que la STC 247/2007 no acepta con carácter general, como veremos.

Creemos por nuestra parte que la tensión existente sobre la licitud o no de que existan tablas estatutarias se hubiera suavizado de haberse dado al artículo 139.1 una interpretación más matizada, esto es, una interpretación consonante con el hecho de que si bien el Estatuto es antes que nada -admitamos estola norma institucional básica de la Comunidad Autónoma, ello no puede eclipsar totalmente el dato de que el Estatuto es también norma de las Cortes Generales y no una ley de exclusiva procedencia autonómica. Ello significa que el principio de igualdad del citado precepto tiene, inercialmente, una proyección intraterritorial indudable y en esta clave debe ser entendido como regla, pero ello no debe descartar absolutamente la posibilidad de que el Estado, a través de la aprobación del Estatuto, vele por asegurar, como reconoce la importante STC 173/1998 antes citada, "una determinada uniformidad normativa en todo el territorio nacional" (Fto. Jur. 10), siquiera con carácter mínimo para evitar desigualdades entre territorios sobre cuestiones esenciales, como pueden ser aquellas en las que el interés autonómico no aparece como algo claro y excluyente de un interés estatal concomitante sobre tales asuntos. En suma, no se ve la razón de por qué, tratándose de Estatutos, el Estado tenga que abdicar de esa función unificadora que debe inspirar la producción de todas sus leyes y confiarla en su totalidad en este caso al mecanismo del artículo 149.1.1 ${ }^{\mathrm{a}} \mathrm{CE}$.

\section{D) El límite del artículo 138.2 CE.}

El recurso del Gobierno aragonés contra el Estatuto valenciano también alega infracción de su artículo 17.1 al principio establecido en el artículo 138.2 CE: "Las diferencias entre los Estatutos de las Comunidades Autónomas no podrán implicar en ningún caso privilegios económicos y sociales". Sobre el alcance del precepto $^{84}$, la Sentencia 247/2007 rechaza la alegación declarando que, a di-

83 "Los principios de unidad y autonomía en el Estatuto de Autonomía de la Comunitat Valenciana" en Comentario al Estatuto de Autonomía de la Comunidad Valenciana (dir. J. M. Baño León) cit. pág. 32 y ss.

${ }^{84}$ Éste fue interpretado por la STC 76/1983 de 5 de agosto, y considerado por el Consejo de Estado en su Informe de 16 de febrero de 2006. Vid. CATALÀ I BAS, A., "La inclusión de una carta de derechos..." en Revista Española de la Función Consultiva, pág. 187. 
ferencia de lo que ocurre con el artículo 139.1, el 138.2 no tiene relación directa con el ámbito de los derechos de los ciudadanos, sino con "la organización y relaciones entre las diversas partes del territorio español, en concreto, con su equilibrio socio económico y con el papel que al respecto ha de desempenar el principio de solidaridad", lo cual no guarda relación con las declaraciones estatutarias de derechos, a no ser que éstas, -añade la sentencia-, supongan en sí mismas la atribución de privilegios económicos o sociales a determinada Comunidad Autónoma, lo que determinaría su inconstitucionalidad (Fto. Jur. 16). Pero tal hipótesis -concluye la sentencia en su Fto. Jur. 20no se da en este caso: porque el artículo 17.1 EACV no establece ningún derecho subjetivo; porque no vincula la función legislativa del Estado, que podrá ejercerla sin condicionamiento alguno; porque es acorde con el sentido del Estado social; y por la razón -aquí el argumento central- de que no se desprende de dicho artículo que haya de producirse ningún privilegio económico o social para la Comunidad Valenciana ${ }^{85}$.

E) La sujeción al posible despliegue por el Estado de la potestad contenida en el artículo 149.1.1 ${ }^{\mathrm{a}} \mathrm{CE}$.

Es consabido el papel central que juega el citado precepto ${ }^{86}$ en el sistema constitucional y los diversos puntos de estudio que plantea, todos ellos trascendentes (sentido y alcance de esa potestad, ámbito material que comprende, etc.); de ello es indicativa la atención que le ha prestado la doctrina, a la que necesariamente hay que remitirse en esta ocasión ${ }^{87}$. Baste recordar aquí

${ }^{85}$ Fto. Jur. 20.c), que abunda en las razones de esta última afirmación.

86 "Art. 149.1. "El Estado tiene competencia exclusiva sobre las siguientes materias: $1^{\text {a }}$ La regulación de las condiciones básicas que garanticen la igualdad de todos los españoles en el ejercicio de los derechos y en el cumplimiento de los deberes constitucionales".

87 Vid., entre otros, PEMÁN GAVÍN, J. M., Igualdad de los ciudadanos..., cit.; BAÑO LEÓN, J. M., Las autonomías territoriales y el principio de unificación de las condiciones de vida, INAP, Madrid, 1988; LÓPEZ GUERRA, L., "La doctrina del Tribunal Constitucional..." en La función del artículo 149.1.1 ${ }^{a}$ CE... cit; TUDELA ARANDA, J., Derechos constitucionales y Autonomía Política, Civitas-IVAP, Madrid, 1994; AJA, E., "El artículo 149.1.1ª de la Constitución como cláusula de cierre del principio de igualdad social" en VV. AA., La función del artículo 149.1.1 ${ }^{a}$ de la CE en el sistema de distribución de competencias, Institut d'Estudis Autonòmics, Barcelona, 1992; BARNÉS VÁZQUEZ, J., Problemas y perspectivas del artículo 149.1.1 ${ }^{a}$ CE, IEA, Barcelona, 2004; CABELLOS ESPIÉRREZ, M. A., "La regulación de los derechos: el papel del Estado y de las Comunidades Autónomas a partir del artículo 149.1.1 ${ }^{a}$ CE" en Estado compuesto y derechos..., cit.; más recientemente en "La relación derechos-Estado Autonómico en la Sentencia sobre el Estatuto valenciano”, cit., págs. 113 y ss. 
-abundaremos en ello al tratar de los Estatutos- que el artículo 149.1.1 ${ }^{\mathrm{a}}$ no constituye en sí mismo un límite frente a los enunciados legales, sencillamente porque no contiene ningún parámetro material para contrastar la validez de esas declaraciones, ni ése es su papel. Lo que sí contiene es la atribución de un poder al legislador estatal para que pueda dictar bases precisamente con el fin de conseguir una igualación de todos los españoles en las posiciones jurídicas fundamentales. Por consiguiente, contra una supuesta extralimitación legal (o estatutaria) no cabe esgrimir como argumento el hecho mismo de la existencia del artículo 149.1.1 ${ }^{\mathrm{a}}$; pero siempre habrá que atenerse a la posibilidad de que el Estado haga legítimo uso de esa potestad e incida sobre cualquier norma del ordenamiento jurídico, incluido un Estatuto de Autonomía, susceptible de comprometer la igualdad referida. Ciertamente, como dice CRUZ VILLALÓN, el artículo 149.1.1 a no permite que haya desigualdad en los territorios respecto de los derechos fundamentales, porque aquí la exigencia de igualdad es total ${ }^{88}$. En fin, el citado precepto constituye un límite absoluto, pero potencial o virtual; constituirán límites reales los que contengan las leyes que eventualmente el Estado dicte a su amparo. Como queda dicho, en el siguiente capítulo insistiremos sobre esta importante cuestión.

\section{LA POLÉMICA SOBRE LA LICITUD DE LA INCLUSIÓN DE PRINCIPIOS, DERECHOS Y DEBERES EN LOS ESTATUTOS DE AUTONOMÍA}

\section{Sobre la oportunidad de su inclusión en los Estatutos}

Antes de abordar la cuestión de si es lícito o no incluir en los Estatutos tablas de principios, derechos y deberes cabe preguntarse si tal inclusión es oportuna o conveniente. Predominan las opiniones doctrinales que no sólo afirman la licitud sino que se muestran beligerantes en favor de tal inserción, invocando argumentos de diverso tipo. Así, se arguye el valor simbólico que comportan tales declaraciones, tanto en el sentido de que expresan las señas

${ }^{88}$ CRUZ VILLALÓN, P., "Los derechos sociales...”, en Estudios sobre el Estado Social... cit., pág. 166. En el mismo sentido, señala DÍEZ-PICAZO que esa potestad "no puede ser suprimida o restringida por un Estatuto de Autonomía; es decir, con normas estatutarias declarativas de derechos o sin ellas, siempre cabrá hacer uso del artículo 149.1.1 a." "¿Pueden los Estatutos de Autonomía...?”, en $R E D C$, cit., pág. 65. 
de identidad de la Comunidad que el Estatuto define ${ }^{89}$ como porque refuerzan el compromiso de las instituciones autonómicas con los valores propios del Estado social de derecho y con el proceso de integración europea ${ }^{90}$ así como que representan una especie de garantía institucional para determinadas instituciones del Estado del Bienestar, así, la Seguridad Social ${ }^{91}$. Se invocan otros argumentos de carácter formal tales como que este tipo de declaraciones es rasgo común a muchos Estados descentralizados políticamente, sean o no estrictamente federales ${ }^{92}$ o el dato de que el fenómeno se inscribe en la lógica del llamado "constitucionalismo multinivel o en red"93. También se ha dicho que la inclusión de esas declaraciones en los Estatutos conlleva una reducción de la operatividad de las fuerzas políticas y con ella una aminoración del riesgo de arbitrariedad que el uso del poder comporta, con el consiguiente refuerzo de la autonomía de las personas frente al poder ${ }^{94}$.

Muy estimables son las opiniones que inciden en la función complementaria de estas tablas o declaraciones respecto de los genuinos derechos fundamentales de la Constitución al añadir a ésta derechos de otro carácter (sociales, económicos, lingüísticos, culturales) ${ }^{95}$. Es muy de resaltar la función, re-

${ }^{89}$ BALAGUER CALLEJÓN, F.: La reforma de los Estatutos..., cit., pág. 53. En análogo sentido, BALAGUER CALLEJÓN, M. L., Reformas estatutarias..., cit., pág. 8; EXPÓSITO, E., "La regulación de los derechos..." en Revista d'Estudis Autonòmics i Federals, cit., para quien además supone "una mejora cualitativa del autogobierno en la medida en que se hace partícipe al ciudadano del ejercicio del poder", pág. 162.

${ }^{90}$ CATALÀ I BAS, A. H., "La inclusión de una carta de derechos..." en Revista Española de la Función Consultiva, cit., pág. 195.

${ }^{91}$ RUIZ-RICO RUIZ, G., "Derechos sociales y reformas de los Estatutos...” cit. pág. 83.

${ }^{92}$ APARICIO WILHELMI, M. y PISARELLO, G., "El reconocimiento de derechos, deberes y principios...”, en El Clip, cit., pág. 2.

93 Ibídem. Por ello, -añaden los autores- si este modelo comporta el reconocimiento de diversos centros de poder normativo (estatales, supra-estatales e infra-estatales), también debería comportar el simultáneo reconocimiento de derechos, deberes y principios que impongan límites y vínculos al ejercicio de dicho poder en cada una de esas escalas.

${ }^{94}$ Ibídem. Tal argumento -ciertamente discutible- invierte o retuerce el utilizado precisamente para desacreditar la bondad de la inclusión de derechos en los Estatutos por perjudicar el normal desarrollo del proceso democrático, según veremos más adelante.

95 CASTELLÀ ANDREU, J. M., "El reconocimiento y garantía de los derechos y libertades de los Estados compuestos. Una aproximación comparada” en Derechos y libertades en los Estados compuestos, Atelier, 2005, pág. 37. 
ferida por APARICIO WILHEMI Y PISARELLO, en virtud de la cual esos derechos, deberes y principios estatutarios permiten enriquecer su percepción constitucional e incluso comportan avances no desdeñables desde el punto de vista de la técnica normativa ${ }^{96}$, hasta el punto de que pueden hacer, como agudamente ha señalado BALAGUER CALLEJÓN, una importante labor de puente hacia futuras reformas constitucionales ${ }^{97}$. Sobre esto último cabe decir que, ciertamente, en el proceso de descubrimiento y gestación -es decir, en la fase previa a su cristalización o alumbramiento- de derechos fundamentales nuevos o de modificación o ampliación de los ya existentes, las Comunidades Autónomas están llamadas a tener una participación notable, precisamente por su rozamiento, cada vez más intenso, con los problemas sociales y las correlativas demandas de los ciudadanos, de tal modo que raro será que los impulsos reformistas no provengan de los territorios. Pero todo ello en el buen entendido de que la consagración misma del derecho fundamental como norma jurídica es competencia del Estado y que la modificación posible de los derechos constitucionales en ningún caso deberá ser consecuencia de iniciativas legales adoptadas prematuramente por las Comunidades Autónomas. Éstas serían, como es obvio, radicalmente nulas.

\section{Sobre la constitucionalidad de la inserción en los estatutos de dichas tablas de principios, derechos y deberes}

A) El presunto impedimento formal: el tenor literal del artículo 147.2 CE. Posturas que se mantienen sobre el contenido posible de los Estatutos.

El artículo $147 \mathrm{CE}$, tras definir los Estatutos en su apartado 1 como "la norma institucional básica de cada Comunidad Autónoma, dentro de los términos de la presente Constitución”, establece en su apartado 2 las materias que deberán contener.

a) La denominación de la Comunidad que mejor corresponda a su identidad histórica.

b) La delimitación de su territorio.

${ }^{96}$ APARICIO WILHELMI, M. y PISARELLO, G., "El reconocimiento de derechos, deberes y principios..." en El Clip, cit., pág. 2.

${ }^{97}$ BALAGUER CALlEjÓN, F., La reforma de los Estatutos..., cit., pág. 53. 
c) La denominación, organización y sede de las instituciones autonómicas propias.

d) Las competencias asumidas dentro del marco establecido en la Constitución y las bases para el traspaso de los servicios correspondientes a las mismas.

Se trata del contenido necesario, sin el cual los Estatutos no existirían como tales. Éstos deben recoger obligadamente dichos extremos (“deberán contener") a lo que hay que añadir que estas materias descritas en el artículo 147.2 CE están reservadas a los Estatutos y, por tanto, sólo son asumibles por la voluntad conjunta del legislador autonómico y el estatal, razón por la que no caben decisiones unilaterales del Estado o de las Comunidades Autónomas sobre tales asuntos ${ }^{98}$.

La expresión "deberán contener" que precede a dicho listado da pie a una doble interpretación: primera, que ésas son precisamente, y no otras, las materias que la Constitución ha dispuesto que se incluyan en los Estatutos de Autonomía como contenido necesario y único de los mismos (interpretación estricta); la segunda considera que con citada fórmula la Constitución fija imperativamente el contenido mínimo, pero deja abierta la posibilidad de que se incluyan otros distintos. Sobre estas dos posiciones básicas se asienta todo el debate existente en torno a la extensión de los Estatutos de Autonomía y la función de éstos y, a la postre, sobre la posibilidad de que éstos proclamen y establezcan derechos, señaladamente derechos sociales; pero estas dos posiciones básicas son susceptibles de ser desgranadas en niveles más matizados, como se verá seguidamente.

En términos generales puede decirse que es mayoritaria la doctrina que aboga por una interpretación amplia del artículo 147.2 CE, es decir, no ceñida a su tenor literal; y esto puede afirmarse tanto en relación con las posturas doctrinales surgidas al hilo de la última oleada de reformas estatutarias como de los comentarios al artículo 147.2 CE realizados con anterioridad, paradójica coincidencia causada por razones muy distintas. En efecto, el grueso de las opiniones doctrinales surgidas en los últimos tiempos postula una interpretación amplia por alinearse con la corriente descentralizadora o por simpatizar

\footnotetext{
98 Sobre la significación de estas materias como reservas estatutarias, vid. AGUADO RENEDO, C., El Estatuto de Autonomía y su posición... cit., págs. 214 y ss. y doctrina allí citada.
} 
con la consagración de los derechos sociales al más alto nivel; en cambio, la doctrina surgida en el contexto de los Estatutos originarios lo que muestra es, salvo contadas excepciones, una cierta apatía, bien ignorando el problema o bien mostrando posiciones abiertas sin mediar especial reflexión, sin duda porque no se barajaba entonces una evolución de los Estatutos como la que hoy presentan los recientemente reformados, aunque bien es verdad que ya los primitivos Estatutos ponían sobre la pista de la cuestión al contener no pocos de ellos no sólo enunciados más o menos retóricos así como normas programáticas, sino auténticos derechos, tales como los lingüísticos y otros que son trasunto de derechos fundamentales.

\section{a) Interpretaciones estrictas sobre el alcance del artículo 147.2 CE.}

Esta línea interpretativa sólo considera lícitos los contenidos estatutarios inequívocamente cubiertos por la Constitución, en los que pueden distinguirse tres niveles: a) un contenido mínimo necesario que viene constituido por las materias descritas en el artículo $147.2 \mathrm{CE}$, a las que es obligado añadir lo relativo a la propia reforma del Estatuto, según resulta de los artículos 147.2 y 152.2 CE; b) un segundo nivel vendría marcado por ciertos contenidos adicionales expresamente previstos como posibles por la Constitución, esto es, sin que la inclusión en los Estatutos sea obligatoria. Se trata, pues, de contenidos potestativos o eventuales, de los que cabe hacer sucinta relación ${ }^{99}$; c) un contenido compuesto de preceptos que guardan con los anteriores una conexión clara, gozando de cobertura constitucional cierta, aunque ésta no se encuentre explicitada. Son contenidos inherentes, indudablemente legítimos, pues como dice AGUADO RENEDO son en realidad especificaciones de algunos de los extremos del 147.2, o "desarrollo" de otros preceptos constitucionales ${ }^{100}$.

99 Señaladamente, la Sentencia 247/2007 cita los artículos 3.2 (expresión de la lengua cooficial), 4.2 (banderas y enseñas propias), 69.5, (sistema de designación de senadores autonómicos), 145.2 (convenios entre Comunidades Autónomas), 149.1.29 (creación de policías autonómicas), 152.1 (órganos esenciales de las Comunidades Autónomas), 152.3 (entidades territoriales supramunicipales), 156 (colaboración con el Estado en materia de tributos), Disposición Adicional $1^{\mathrm{a}}$ (actualización del régimen foral), Disposición Adicional 4ª (mantenimiento de las Audiencias Territoriales preexistentes). Vid. asimismo una relación de estos supuestos en CARRILLO LÓPEZ, M., "Los derechos, un contenido..." en Revista Española de Derecho Constitucional, cit., pág. 55.

${ }^{100}$ Se refiere el autor citado a los preceptos relativos a la Administración autonómica, organización de las instituciones autónomas propias, regulación de la Administración local o estructura territorial (que se ocupa de los municipios, comarcas y Diputaciones provinciales), las relaciones con la Administración del Estado y con las demás Comunidades Autónomas, el control de la actividad de los órganos autonómicos, El Estatuto de Autonomía y su posición..., cit., pág. 318. 
Con esta tercera hipótesis quedan cerrados los supuestos que se encuadrarían dentro de una interpretación estricta, es decir, la comprensiva del artículo 147.2 CE y de su "contexto próximo".

El sector doctrinal que constriñe el contenido posible de los Estatutos a este ámbito estricto es claramente minoritario ${ }^{101}$ pero ha tenido la virtud de poner en marcha un debate absolutamente necesario en el momento oportuno. En este sentido es obligado destacar la incisiva reflexión del profesor DÍEZ-PICAZO, causante de una réplica en cadena de numerosos constitucionalistas. Para este autor "hacer declaraciones de derechos no está entre las materias del artículo 147.2 CE", así que a la vista de este precepto "los Estatutos de Autonomía son un tipo de norma con contenido constitucionalmente tasado" 102 , y señala que la idea de que existe un contenido necesario y otro meramente posible es una creación del Consejo Consultivo de Cataluña formulada en su dictamen de 1 de septiembre de 2005 sobre el proyecto del nuevo Estatuto de Cataluña, sin verdaderos apoyos jurisprudenciales o doctrinales anteriores $^{103}$. Y en un trabajo posterior, replicando a CAAMAÑO DOMÍNGUEZ $^{104}$, critica a éste por interpretar el artículo 147 CE en clave de Estado federal, lo que a su juicio implica convertir los Estatutos de Autonomía en una especie de "extrañas Constituciones elaboradas y aprobadas con el concurso del legislador estatal y, además, vinculantes también para el propio Estado ${ }^{105}$ ".

La postura de DÍEZ-PICAZO es nítidamente contraria a los contenidos estatutarios no conectados claramente a la letra de la Constitución. Así lo confiesa el autor: lo que aduce en contra de las normas estatutarias declarativas de

${ }^{101}$ Por su relevancia cabe citar a autores como MARTÍNEZ LÓPEZ-MUÑIZ, J. L., para quien el artículo 147 CE predetermina el ámbito de cuestiones que deben incluirse en los Estatutos, cuya misión no es regular funciones y materias sino organizar la Comunidad Autónoma y determinar sus competencias. "Límites constitucionales generales..." en La reforma de los Estatutos... cit., págs. 95 y 120. Asimismo, cabe alinear a AGUADO RENEDO, C., dado el escaso valor que otorga a las normas programáticas incluidas en los Estatutos y su postura negativa en cuanto a los derechos, cit. El Estatuto de Autonomía y su posición...”, págs. 306, 335 y 356.

102 DÍEZ-PICAZO GIMÉNEZ, L. M., “¿Pueden los Estatutos de Autonomía...?”, cit., pág. 65.

103 Ídem, págs. 66.

104 "Sí, pueden...", cit.

105 DÍEZ-PICAZO GIMÉNEZ, L. M., ídem, pág. 65. 
derechos vale también para los preceptos de los Estatutos que establecen deberes o principios rectores en materia económica y social ${ }^{106}$. En cambio, no muestra beligerancia alguna contra las normas estatutarias que contienen derechos no sustantivos, o sea, los de corte institucional, lo que no deja de ser una fisura seria en su armazón argumental que el autor tratará de justificar como diremos más adelante.

Por su parte, la STC 247/2007 se aparta de esta doctrina restrictiva en el arranque mismo de su argumentación (Fto. Jur. 11). Por ello corresponde considerar su doctrina en el epígrafe siguiente. No obstante, cabe dejar constancia aquí de la opinión de algunos magistrados disidentes, identificada con la interpretación estricta sobre el alcance del artículo 147.2 CE que se acaba de exponer ${ }^{107}$.

\section{b) Interpretaciones amplias sobre el contenido estatutario posible.}

Nos referimos ahora a contenidos estatutarios no previstos en la Constitución. Dentro de este gran apartado, pueden distinguirse igualmente varios niveles en orden gradual: a) el primer escalón, constitutivo del cuarto nivel (dentro de la escala que venimos formulando), resulta de la adición a los Estatutos de normas programáticas o principios rectores, es decir, enunciados cuya característica común es la de su inaplicabilidad directa. En este nivel se inscriben la mayoría de los Estatutos originarios y, lógicamente, a él hay que adscribir las posiciones doctrinales intermedias o "moderadas"; b) el quinto nivel viene configurado por los Estatutos que, además de normas programáticas o principios rectores, proclaman derechos, abstracción hecha en este lugar de cuál sea el valor que quepa atribuir a tales proclamaciones. En puridad,

106 Idem, cit., pág. 63.

${ }^{107}$ El magistrado don Ramón RODRÍGUEZ ARRIBAS señala en su voto particular que la cuestión nuclear del recurso, sobre si en los Estatutos de Autonomía caben tablas o declaraciones de derechos y en su caso derechos subjetivos... debió resolverse contundentemente en sentido negativo en ambos aspectos. En la misma línea, aunque matizadamente, el magistrado don Javier DELGADO BARRIO afirma que no es admisible el establecimiento en los Estatutos de derechos subjetivos relacionados con el artículo 147.2.d), pues el Estatuto es norma atributiva de competencias y no de ejercicio de éstas. No hay precepto constitucional que se dirija al Estatuto para abrir el camino a esos derechos. Por excepción -añade el voto particular- sólo es viable la inclusión en los Estatutos de derechos subjetivos derivados de expresa previsión constitucional, o que sean complemento adecuado en la regulación estatutaria de las instituciones autonómicas. 
dentro de este nivel hay que distinguir a su vez dos escalones: el inferior, constituido por el reconocimiento en los Estatutos de derechos subjetivos relacionados con las "instituciones autónomas propias", sobre cuya posibilidad y licitud no existe reserva alguna en la doctrina ni en la jurisprudencia; y el superior, resultante de la inclusión de derechos subjetivos que llamamos sustantivos, que constituyen el objeto central de la gran polémica a la que asistimos en la actualidad; c) cabe añadir un sexto y último peldaño a esta escala de posibilidades; esto es, la admisión en los Estatutos no sólo de derechos de toda clase sino cualquier contenido estimado relevante para la proyección del Estatuto y el impulso de la autonomía, con el solo límite de que no infrinja la Constitución. La escala anteriormente descrita no es simple especulación, de modo que con arreglo a ella podrían ser ordenadas las ya muy numerosas opiniones doctrinales emitidas al respecto, incluida la postura del TC a través de sus Sentencias 247 y $249 / 2007$.

La vía más fácil para rebatir las interpretaciones estrictas del artículo 147.2 CE es la negativa: el hecho de que la Constitución no prevea la inclusión de derechos en los Estatutos no permite afirmar que los prohíba ${ }^{108}$; o bien buscar apoyo -como hace la STC 247/2007 en su Fto. Jr. 11- en decisiones anteriores. Ciertamente, así lo hace de forma confesada dicha Sentencia al reconocer que "a este Tribunal no se le ha planteado hasta el momento, como objeto autónomo de enjuiciamiento, cuál sea el contenido legítimo de un Estatuto de autonomía", afirmando seguidamente que "en las escasas ocasiones en que ha debido realizar determinadas apreciaciones al respecto, "éstas no se han basado en una mera interpretación literal del citado artículo 147 CE". Y en prueba de lo dicho la Sentencia invoca cuatro resoluciones que le sirven de precedente, por cierto no muy determinantes a dicho efecto, ya que aquéllas se refirieron a contenidos que guardaban una clara relación con el artículo $147 \mathrm{CE}^{109}$. Así, la solución

\footnotetext{
108 Entre otros muchos autores, ÁLVAREZ CONDE, E., Reforma constitucional y reformas estatutarias, Iustel, Madrid, 2007, pág. 351. Asimismo EXPÓSITO, E., "La regulación de los derechos..." en Revista d'Estudis Autonòmics i Federals, cit., pág. 150. AGUDO ZAMORA, M. J., Comentarios al Estatuto de Andalucía, cit. pág. 267.

109 Así, la STC 36/1981 versaba sobre la inviolabilidad e inmunidad de los miembros de las Asambleas legislativas de las Comunidades Autónomas y consideró que era un contenido natural del Estatuto, perfectamente incardinable en el artículo 147.2.c) alusivo a "la denominación, organización y sede de las instituciones autonómicas propias”. Por su parte, tampoco brinda un apoyo decisivo al respecto la STC 89/1984, segunda de las recordadas por el TC, pues ésta se limitó a declarar que el artículo 147.2 CE realiza "la determinación del contenido mínimo de los Esta-
} 
sostenida por la Sentencia no está realmente en línea con los antecedentes en que se apoya ${ }^{110}$.

Lo relevante es que la Sentencia, sobre dicha base, llega a una primera conclusión (Fto. Jur. 11, in fine) cual es la de proclamar la legitimidad de todo contenido estatutario "siempre que esté conectado con las específicas previsiones constitucionales relativas al cometido de los Estatutos", pronunciamiento éste que no logra despejar los puntos fuertes de la cuestión, esto es, lo que debe entenderse por "conexión" y por "cometido" de los Estatutos.

Desde una perspectiva más institucional algunos autores ponen el énfasis en el dato de que el Estatuto no es una ley cualquiera sino precisamente la "norma institucional básica" de la Comunidad Autónoma, como dice el propio artículo $147 \mathrm{CE}$, apartado 1. Así, MARC CARRILLO sostiene que el contenido de los Estatutos no tiene por qué quedar constreñido a la regulación de los aspectos auto-organizativos y a la fijación de las competencias que concretan el autogobierno de la Comunidad Autónoma. "Nada excluye -diceque en la definición del alcance del autogobierno, el legislador estatuyente pueda, por ejemplo, fijar los objetivos de las competencias asumidas y los límites en su ejercicio por los poderes públicos de la Comunidad Autónoma"111. En la misma línea, VIVER I PI SUNYER resume la idea diciendo que "hay pocas cuestiones más propias de una norma institucional básica que el reconocimiento de derechos de sus miembros frente a sus órganos de autogobierno $^{112 "}$.

tutos”, sin prejuzgar nada más. Y aún menos sólido es el apoyo que el TC ha querido ver en la STC 99/1986, pues ésta aludió a que "los límites en que han de enmarcarse los contenidos estatutarios, de acuerdo con lo establecido en el artículo $147 \mathrm{CE}$, son sólo los establecidos constitucionalmente", lo que tampoco da alas precisamente para hacer interpretaciones de dicho artículo muy alejadas de su contexto próximo, es decir, del constituido por los contenidos necesarios, eventuales e inherentes a los que nos referimos supra. La última de las Sentencias citadas -225/1998- expresa, de pasada, una ambigüedad que no parece muy útil para edificar sobre ella tesis alguna; en este sentido vid. el comentario a esta Sentencia en FERNÁNDEZ FARRERES, G., ¿Hacia una nueva doctrina constitucional...? , cit., pág. 92, nota 39 .

110 Así lo detecta también FERNÁNDEZ FARRERES, G.: idem, págs. 99 y 111.

${ }^{111}$ DÍEZ-PICAZO critica esta invocación a la idea del autogobierno, afirmando que en todo caso éste deberá conformarse y ejercerse dentro de lo previsto por la Constitución, incluido su artículo 147.2. “¿Pueden los Estatutos de Autonomía...?” en Revista Española de Derecho Constitucional, cit., pág. 53.

112 “L’Estatut de 2006” en Activitat Parlamentaria, núm. 10, 2006, pág. 42. 
Pues bien, ésta es la tesis en la que finalmente se inscribe la STC 247/2007 y que desarrolla en su Fto. Jur. 12, donde queda realzado el valor del principio dispositivo en favor de las Comunidades Autónomas, lo que les permitirá incluir con toda normalidad, amén de las previsiones del artículo 147.2 CE otras cuestiones derivadas de dichas previsiones "relativas a las funciones de los poderes e instituciones autonómicos, tanto en su dimensión material como organizativa, y a las relaciones de dichos poderes e instituciones con los restantes poderes públicos estatales y autonómicos, de un lado, y con los ciudadanos, de otro". Y debe notarse que todos estos contenidos, inclusive los no previstos en el artículo 147.2 CE, quedan por igual congelados por obra del Estatuto ya que la Sentencia -Fto. Jur. 11-, siguiendo la tesis de la 225/1998 a la que invoca, niega que dichos contenidos adicionales carezcan de rigidez y, por tanto, pudieran ser reformados por procedimiento distinto al del Estatuto ${ }^{113}$.

Este principio dispositivo ${ }^{114}$ viene a ser la herramienta que permite alejar el problema de la órbita del artículo 147.2 CE y de su contexto próximo, posibilitando así la inclusión en el Estatuto del "contenido que, aun no estando expresamente señalado por la Constitución es complemento adecuado ${ }^{115}$ por su conexión con las aludidas previsiones constitucionales, adecuación que ha de entenderse referida a la

113 Vid. sobre este punto las consideraciones de FERNÁNDEZ FARRERES, G., y su crítica a determinadas opiniones doctrinales que han postulado la degradación del rango normativo de esos contenidos adicionales tal como se ha justificado por la jurisprudencia constitucional en el caso de esas leyes orgánicas, ¿̇Hacia una nueva doctrina constitucional... ? cit. págs. 88 y ss.

${ }^{114}$ En otra parte de la Sentencia -Fto. Jr. 5- ésta afirma que el principio dispositivo está ínsito en la Constitución y "otorga un importante margen de decisión al legislador estatutario". El voto particular del magistrado don Jorge RODRÍGUEZ ZAPATA se expresa sobre este punto con toda contundencia; así, dice (aptdo. 5): "La Sentencia reconoce en forma somera el principio de unidad (FJ 4.a) pero trae a un destacado primer plano (FFJ 4,5,12,15, et passim) el denominado "principio dispositivo" que le sirve para dar una lectura original del funcionamiento de nuestro "Estado de las Autonomías [...] Nadie niega doctrinalmente la existencia inicial del 'principio dispositivo' en nuestra Constitución de 1978 pero, tras la división del territorio nacional en diecisiete Comunidades Autónomas, el mismo había pasado a una situación de retiro, que el Consejo de Estado recomendó recientemente transformar ya en jubilación (Cfr. Dictamen 1/2005, apartado 4.1.2) [...] En el marco actual, en el que se procede a un tercer período de reformas de los Estatutos, no comparto que se pueda dar el relieve que pretende la Sentencia al denominado principio dispositivo" Y añade en el aptdo. 6: "La Sentencia convierte ese 'principio dispositivo' en un auténtico Deus ex machina de nuestro sistema autonómico. Esa pseudodivinidad, bajada a escena de la mano de cierta doctrina y en forma artificial, sirve para relativizar el principio constitucional de igualdad".

${ }^{115}$ Frente a estas consideraciones sale al paso el voto particular del magistrado don Vicente CONDE MARTÍN DE HIJAS, quien afirma que las declaraciones estatutarias de derechos a favor de los ciudadanos españoles residentes en una determinada Comunidad Autónoma no son in- 
función que en sentido estricto la Constitución encomienda a los Estatutos, en cuanto norma institucional que ha de llevar a cabo la regulación funcional, institucional y competencial de cada Comunidad Autónoma" (Fto. Jur. 12, in fine). Como puede verse, también en este segundo acercamiento a la definición del contenido estatutario posible la Sentencia sigue utilizando conceptos indeterminados ("complemento adecuado", "conexión”, "función de los Estatutos"...) y todo ello, paradójicamente, dicho inmediatamente después de su propia advertencia sobre que tal contenido estatutario "no puede ser entendido de una manera difusa, en atención, entre otras razones, a la especial rigidez que le caracteriza”.

En suma, la Sentencia pone el nivel del contenido posible del Estatuto en un lugar muy alto (al menos aparentemente), pues, teniendo en cuenta la potencia que atribuye al principio dispositivo, la consecuencia es que podrían incluirse en los Estatutos derechos de cualquier clase, ya que sería bien difícil sostener que tales enunciados no constituyen un "complemento adecuado" o no guardan una "lógica conexión" con las competencias asumidas. De este modo, la Sentencia sobrepasa la postura de algunos autores que optaron por considerar como contenido estatutario lícito las normas programáticas o principios rectores pero no la proclamación de derechos ${ }^{116}$, dando por el contra-

cluibles en ninguna previsión expresa de la Constitución, ni pueden considerarse complemento adecuado de ninguna previsión constitucional. La simple conexión hipotética de la declaración de derechos con una concreta competencia atribuida en el Estatuto de la Comunidad Autónoma lo es con un contenido del Estatuto, pero no con una previsión constitucional que es, según se ha dicho, el elemento clave para determinar el contenido constitucionalmente posible de un Estatuto de Autonomía. Análogas reservas muestra el voto particular del magistrado Sr. RODRÍGUEZ ZAPATA, tachando de ambiguo el alcance que la Sentencia atribuye a los Estatutos pues de esta forma caben en ellos, por obra del omnipresente "principio dispositivo", declaraciones y enunciados de derechos estatutarios que vinculan a los poderes públicos.

116 Con oportuna precisión VIVER I PI-SUNYER detecta la distinción, a efectos del contenido posible de los Estatutos, entre principios rectores, de una parte y de derechos, por otra, señalando que los primeros no plantean problemas mientras que sí los plantean los listados de derechos y deberes en La reforma de los Estatutos ... cit., pág. 31. El profesor MUÑOZ MACHADO también conjuga esta importante distinción -que no manejan a estos efectos la mayoría de los autoresanalizando concienzudamente el valor de las normas programáticas y los requisitos para que ésas puedan figurar lícitamente en los Estatutos, de lo que implícitamente se deduce que el autor no considera procedente la inclusión de derechos ya que no se refiere a ellos, Derecho Público... cit., págs. 37 y ss. No obstante, en su Tratado de Derecho Administrativo y Derecho Público General, II, (2006), cit., dice, respecto a las declaraciones de derechos y a los mandatos al legislador contenidos en los Estatutos, que "de la legitimidad de estas incorporaciones no cabe dudar en términos generales", pág. 717. Semejante es la postura de FERRERES COMELLA, V., según se deduce de su estimación de que los derechos limitan el autogobierno, mientras que los principios rectores lo hacen en un grado mucho menor, "Derechos, deberes y principios..." en Derechos, deberes... cit., pág. 23. 
rio la razón al sector doctrinal que ha postulado la procedencia de incluir tablas de derechos en los Estatutos ${ }^{117}$ y a los Órganos Consultivos Autonómicos que han dictaminado sobre el particular ${ }^{118}$. Pero lo dicho nada tiene que ver

117 Entre otros muchos pueden citarse GARCÍA ÁLVAREZ, M. y GARCÍA LÓPEZ, R., para quienes existe "una clara conexión entre las competencias materiales asumidas por las Comunidades Autónomas y los derechos que deben limitar su ejercicio... siendo legítima la opción de incluir en los Estatutos declaraciones de derechos y principios rectores", "El modelo de estado social ante la reforma de los Estatutos de Autonomía" en La reforma de los Estatutos de Autonomía, Revista Jurídica de Castilla y León, 2003, pág. 393. En similares términos CATALÀ I BAS, A. H., "La inclusión de una carta de derechos..." en Revista Española de la Función Consultiva, cit. págs. 189 y 198-199; LASA LÓPEZ, A., "Derechos sociales y Estado Autonómico: el Estatuto de Autonomía como instrumento normativo de garantía de los derechos sociales" en El Estado Autonómico: integración, solidaridad y diversidad, vol.2,VV. AA., INAP-Colex, Madrid, 2005, págs. 521-522; PÉREZ AYALA, A., "En torno al Estado social autonómico" en El Estado autonómico... cit., pág. 557 y ss.; EXPÓSITO, E., "La regulación de los derechos..." en Revista d'Estudis...cit., pág. 150; BIGLINO CAMPOS, P., "Los espejismos..." en Derechos, deberes y principios...cit., pág. 44; BALAGUER CALLEJÓN, M. L., "Reformas estatutarias..." en Revista General de Derecho Constitucional, cit., pág. 8; CASTELLÀ ANDREU, J. M., "El reconocimiento y garantía de los derechos y libertades en los Estados compuestos. Una aproximación comparada" en Derechos y libertades de los Estados compuestos, Atelier, Barcelona, 2006. RODRÍGUEZ-VERGARA DÍAZ, A. J., con su singular matización de que sólo deben incluirse en el Estatuto los derechos sociales que ya hayan sido establecidos por las leyes de las CCAA en materia de competencia autonómica, "Ciudadanía europea, derechos sociales y Estatutos de Autonomía: tres propuestas de reforma” en El Estado autonómico..." cit. pág. 521.

118 Así, el Dictamen 269 de 1 de septiembre de 2005 sobre la Proposición del Estatuto de Cataluña que considera la incorporación de un título dedicado a derechos, deberes y principios "única opción legítima desde la óptica constitucional, por dos razones: a) porque el Estatuto como norma institucional básica de Cataluña (art. 147.1 CE) y también como norma del Estado derivada de la Constitución "concreta el derecho a la autonomía política" de tal forma que los órganos de los poderes de Cataluña ejercen las funciones que el Estatuto les ha encomendado para llevar a término las políticas públicas que crean pertinentes, de acuerdo con la legitimidad que les confiere la representación política obtenida en las elecciones, en el marco de las competencias que el Estatuto, como norma subconstitucional, ha establecido; b) es consecuente con la voluntad de concreción material y funcional de las competencias, que se concreten los derechos y deberes que estas competencias generen como también los principios que los informan”. En el mismo sentido, el Dictamen del Consejo Consultivo de Andalucía de 2006 no entiende contrario al ordenamiento constitucional vigente la inclusión de un catálogo de derechos y deberes, pues "no suscita duda que los derechos que se reconocen están ligados a las competencias de la Comunidad Autónoma toda vez que los derechos sociales del presente título no suponen una alteración del régimen de distribución de competencias, ni la creación de títulos competenciales nuevos. Y, en segundo lugar, tampoco suscita duda que no registren en modo alguno los que están previstos en la Constitución, sino que se amplían o fortalecen”. De forma análoga se pronuncian los dictámenes del Consejo Consultivo de Canarias 68/2006, de Galicia de 27 de enero de 2006, de Castilla y León de 15 septiembre 2006. Una síntesis de estos dictámenes en ÁLVAREZ CONDE, E., Reforma constitucional y reformas estatutarias, cit. págs. 277 y ss. 
con la realidad; es pura apariencia, dado el llamativo rebaje que la Sentencia acaba dando al tema de los derechos estatutarios, según veremos más adelante. En todo caso, la Sentencia desautoriza las dos hipótesis extremas, es decir, tanto la interpretación literal del artículo 147.2 CE, como aquélla según la cual cabría en los Estatutos cualquier contenido con tal de que no fuera contrario a la Constitución ${ }^{119}$.

Creemos que la Sentencia acierta en cuanto a la interpretación del contenido estatutario posible (aunque no en la desnaturalización que luego hace de ese contenido). Resulta inviable abordar la interpretación del precepto sin tener en cuenta el precedente, realmente aplastante, de la masiva consagración de derechos de orden social que la legislación autonómica ha venido produciendo desde el inicio del sistema. Las normas deben ser interpretadas teniendo el cuenta el contexto y la realidad social del tiempo en que han de ser aplicadas (art. 3.1. C. Civil). Era de todo punto lógico que en la fase inicial del sistema autonómico los Estatutos se acomodaran a los mínimos contemplados en el artículo 147.2, aparte de que poco más podían decir; pero aquella realidad ya no existe, es otra, y no cabe aferrarse a la literalidad de dicho precep-

\footnotetext{
119 Con mayor o menor exactitud pueden adscribirse a esta línea interpretativa las opiniones, por ejemplo de LEGUINA VILLA, para quien, aparte del contenido mínimo, necesario y suficiente, ello "no excluye la incorporación a cada Estatuto de otras determinaciones que, sin vulnerar la Constitución, delimitan adicionalmente el marco autonómico dentro del cual pretendan desenvolverse las instituciones de cada comunidad", Constitución española de 1978. Estudio sistemático dirigido por los Profesores Alberto Predieri y Eduardo García de Enterría, pág. 793; más recientemente y ya en el contexto de las nuevas reformas estatutarias, vid. del mismo autor "La transferencia o la delegación de competencias por medio del Estatuto de Autonomía” en Estudios sobre la reforma del Estatuto, Institut d'Estudis Autonòmics, Generalidad de Catalunya, 2004, págs. 199 y ss. Análogamente, ÁLVAREZ CONDE, E. considera incluibles todas aquellas materias que no estén reservadas a la Constitución y al legislador estatal, así como aquellos contenidos que sean de interés para la Comunidad Autónoma respectiva, y que no implique una usurpación de funciones o competencias de otros titulares ni la imposición de mandatos imperativos a los mismos; Reforma constitucional y reformas estatutarias, cit. pág. 290-291; y asimismo en su Curso de Derecho Constitucional, cit., pág. 510 y ss. También hay que adscribir a esta posición abierta a MUÑOZ MACHADO, S., aunque su postura originaria era mucho más estricta como vimos supra. Cfr. su posición actual en Tratado de Derecho Administrativo y Derecho Público, II, cit. pág. 719 y ss.; CARRILLO LÓPEZ, M., para quien es posible la inclusión de todo lo que sea inherente al autogobierno, "Los derechos, un contenido..." cit. págs. 25 y ss.; ENTRENA CUESTA, R., quien junto al contenido esencial del artículo 147.2 CE admite un contenido eventual que dependerá en cada caso de la voluntad de sus redactores, "Comentario al artículo 147 de la Constitución" en Comentarios a la Constitución, dir. Fernando Garrido Falla, $3^{\circ}$ ed., Civitas, Madrid, 2001, pág. 2524; y análogamente MARTÍN OVIEDO, J. M., "Estatutos de Autonomía. Su contenido y reforma" en Comentarios la Constitución española (dir. Oscar Alzaga), cit., pág. 134.
} 
to congelando una interpretación estricta que sí era lógica en aquel momento fundacional, pero ya no. Cada Comunidad Autónoma ha ido labrando su propia historia particular con la creación de derechos, deberes y posiciones jurídicas de toda índole; resulta bien difícil eludir esta imponente realidad y negar de plano que esa ejecutoria no pueda quedar plasmada en la norma institucional básica de la Comunidad Autónoma cuando ha llegado la ocasión de hacerlo. En fin, resulta paradójico negar la posibilidad de que un Estatuto proclame un derecho determinado cuando puede darse el caso de que éste ya esté creado por una simple Ley de la Comunidad Autónoma.

Por tanto, desde el punto de vista formal no vemos razones de peso que impidan interpretar el artículo 147.2 CE en el sentido amplio con que lo hace la STC 247/2007. Cierto es que cabe argüir contra ello razones de otra índole, o sea, materiales o de fondo, como veremos seguidamente; pero éstas tendrían que ser especialmente potentes para poder doblegar esa fuerte presunción de legitimidad que juega a favor de los Estatutos en cuanto al hecho mismo de que luzcan tablas de derechos, principios y deberes.

B) Los argumentos de fondo, a favor y en contra, sobre los enunciados de principios, derechos y deberes de los Estatutos de Autonomía.

Lo primero a tener en cuenta es que en la actualidad ha quedado absolutamente descartada toda posibilidad de discusión sobre si los Estatutos de autonomía pueden fijar objetivos, formular programas o proclamar principios rectores. Todo enunciado que no se proponga ser inmediatamente aplicable en el plano jurídico es aceptado como contenido lícito de un Estatuto. Por tanto, la polémica -aunque formalmente esté zanjada en la actualidad por la STC 247/2007- queda situada en un nivel superior, el de la posibilidad o no de reconocimiento de derechos subjetivos de eficacia directa, lo que diluye toda posible discusión sobre la procedencia o no de incluir en los Estatutos normas programáticas o principios rectores. El "problema" que un día representaron estas "normas programáticas", reputadas antaño por muchos autores como cuerpos extraños incrustados en los Estatutos, ha dejado de ser un problema.

Otro aspecto a descartar deriva de la aceptación, tanto por el Tribunal Constitucional como por la doctrina, de que los Estatutos puedan contener verdaderos derechos subjetivos, dotados de eficacia jurídica directa, que dimanen del artículo 147.2.c), esto es, los relacionados con "la denominación, 
organización y sede de las instituciones autónomas propias"120. En efecto, existe el más absoluto consenso sobre la posibilidad de que los Estatutos contengan esta suerte de derechos subjetivos. El propio DIEZ-PICAZO, destacado detractor de la inclusión de derechos en los Estatutos, los justifica con base en dos argumentos: a) las normas relativas a la organización institucional suelen ser moralmente neutras, mientras que las normas declarativas de derechos, deberes y principios implican casi siempre una toma de posición acerca de relevantes problemas de ética pública (el origen y el fin de la vida humana, el papel de la religión en la esfera pública, el uso de las lenguas, la presencia de uno u otro sexo en los cargos públicos...); b) aunque esas normas estatutarias relativas a la organización imponen a veces mayorías cualificadas para ciertas decisiones -o sea, el factor de rigidez que al propio autor le lleva a rechazar la introducción de opciones políticas en los Estatutos- se trata de "algo inherente y excepcional" que no restringe materialmente el terreno del proceso político democrático, es decir, de lo que puede ser discutido y votado ${ }^{121}$, argu- $^{-}$ mentación que ha sido rebatida por CAAMAÑO DOMÍNGUEZ ${ }^{122}$.

La STC 247/2007 se pronuncia con la mayor contundencia sobre la licitud de la proclamación por los Estatutos de estos derechos subjetivos de corte institucional:

“... son los Estatutos, precisamente, la concreta fuente constitucionalmente prevista para dotar de sentido y alcance material a la institución de que se trate con la orientación que cada uno de ellos considere adecuada dentro del marco de la Constitución. De este modo, dichas regulaciones estatutarias, llamadas constitucionalmente a producir una vinculación directa de los poderes públicos de la Comunidad, pueden generar también verdaderos derechos subjetivos".

${ }^{120}$ La propia Sentencia cita como ejemplos el reconocimiento de los derechos de inviolabilidad e inmunidad de los parlamentarios autonómicos (S. 36/1981 de 12 de noviembre, FJ 4), de cooficialidad lingüística (S. 82/1986 de 26 de junio, FFJJ 2, 3, 5, 14), designación de Senadores por las Comunidades Autónomas (S. 4/1992 de 13 enero, FJ 3), sistema de representación proporcional de las Asambleas Legislativas de las Comunidades Autónomas (S. 225/1998 de 25 de noviembre, FJ 6 y 7 ).

${ }^{121}$ DÍEZ-PICAZO GIMÉNEZ, L. M., “¿Pueden los Estatutos...?” en REDC, cit., pág. 73.

122 "Sí, pueden..." cit., pág. 41, nota 13. La argumentación de CAAMAÑO, viene a decir, en síntesis, que ciertas decisiones organizativas guardan muy estrecha relación con la ética pública y no son moralmente neutras. 
Queda claro, pues, que este aspecto de la cuestión cae también fuera de toda controversia. Nadie ha discutido que los derechos de esta clase puedan figurar en los Estatutos como genuinos derechos subjetivos, ni su eficacia directa sin necesidad de interpositio legislatoris, lo que permite decir que, siendo esto así tampoco, debe haber razón técnica que impida decir lo mismo de los demás derechos subjetivos, o al menos de buena parte de ellos. Pero la STC 247/2007 es tajante al respecto; para ella los apartados b) y c) del artículo 147.2 CE son dos mundos diferentes, aunque no haya explicado por qué esto sea así.

Según venimos de ver, una vez excluidos los aspectos no controvertidos, la materia en debate es la que afecta de lleno al ámbito de los derechos sociales, esto es, desarrollo de derechos fundamentales de corte social, especificación de los mismos, derechos subjetivos que traen causa de los principios rectores del Cap. III, Tít. I de la CE e incluso del Derecho internacional y comunitario, y derechos sociales nuevos, fruto de la más pura creación estatutaria. Ninguno de estos contenidos, según la STC 247/2007, cabe en un Estatuto de Autonomía en calidad de derecho público subjetivo. La sentencia pasa por ellos como si se tratara de algo marginal o complementario respecto a los derechos relativos a las "instituciones autónomas propias"; eso sí, es bien explícita al admitir que los parlamentos autonómicos sí pueden configurar "verdaderos derechos públicos subjetivos de los ciudadanos", función que niega de plano a los Estatutos, lo que da un sesgo al asunto ciertamente llamativo.

Hay que reconocer que el advenimiento de la Sentencia 247/2007 destruye en gran medida el valor de los argumentos que venía manejando la doctrina científica acerca del tema en cuestión. Por ello pudiera considerarse incluso improcedente insistir aquí en planteamientos ya sobrepasados por la propia autoridad de la Sentencia. Mas no es descartable que el TC tenga que matizar o reconsiderar esa afirmación tan contundente de que los derechos proclamados por los Estatutos no son derechos en ningún caso, sobre todo cuando tenga a la vista tablas bien nutridas y organizadas tanto de derechos como de principios rectores, como es el caso del Estatuto de Cataluña, supuesto, dicho sea de paso, bien distinto al del Estatuto valenciano, pues en éste la presencia de derechos es muy escasa aunque paradójicamente haya sido uno de ellos, el derecho al agua -art. 17 EACV-, el objeto de la discordia que estamos considerando.

Por todo ello resulta oportuno recordar a continuación las claves del debate sobre los derechos estatutarios. 


\section{a) Primera cuestión. Sobre la relación entre los derechos fundamentales y las} Cartas estatutarias de derechos.

Más arriba quedó resaltada la importante presencia en los Estatutos de derechos fundamentales de la Constitución o proyecciones de éstos lo cual plantea la necesidad de delimitar muy nítidamente la frontera de lo admisible en esta materia, algo que requiere mucha precisión pues hay mucho en juego para la propia conformación del ordenamiento jurídico y la unidad del Estado. Y también quedó dicho que la Sentencia 247/2007 no trata esta cuestión con la claridad debida. Así, comienza afirmando -Fto. Jur. 15 d- que los derechos constitucionales "no pueden ser objeto de regulación por los Estatutos de Autonomía", lo que no es del todo cierto pues es doctrina constitucional que el legislador autonómico puede regular aspectos complementarios o secundarios del derecho fundamental (STC 173/1998). Por tanto, de entrada, es obligado sobreinterpretar lo que presuntamente la Sentencia ha querido distinguir, esto es, lo que es "regular" -lo que corresponde hacer al Estado- e "incidir", o sea, lo que pueden hacer las leyes autonómicas o los Estatutos. Pero lo grave es que la Sentencia no se pare a explicar cumplidamente lo que signifique "incidir" o cuáles sean las modalidades de esa "incidencia", cuestión ésta a la que se acerca sin precisión alguna. Así, tras la lapidaria afirmación antes citada, la Sentencia continúa diciendo lo siguiente:

"Sin embargo, si el legislador estatutario, simplemente, reprodujera los derechos constitucionales [...] lo relevante desde la perspectiva de su constitucionalidad será el alcance de dicha reproducción. En tal sentido, si el legislador estatutario 'va más allá' de la mera reproducción e incide en los derechos fundamentales, tales previsiones, que tendrán la eficacia señalada en el párrafo c) anterior, sólo serán legítimas si, además, guardan relación con algunas de las competencias asumidas por la Comunidad Autónoma, incurriendo en inconstitucionalidad en caso contrario" ${ }^{23}$.

En suma, de tal pronunciamiento se puede colegir que los conceptos que la Sentencia maneja son tres: a) la regulación del derecho, que en todo caso co-

${ }^{123}$ El magistrado Sr. RODRÍGUEZ ARRIBAS se opone a estas consideraciones de la Sentencia, diciendo que "si el Estatuto de Autonomía viene a declarar los mismos derechos que se establecen en la Constitución, ya sea por remisión o por la defectuosa técnica legislativa de la mera reproducción, resultan inútiles o superfluos y si contienen derechos diferentes o inciden en la regulación de los que la Constitución proclama, dada la naturaleza territorialmente limitada de la norma estatutaria, se producirá una vulneración del artículo 139.1 de la Constitución”. 
rresponde al Estado; b) la reproducción pura y lisa del derecho fundamental, no inconstitucional en sí y a la que sólo cabe reprochar mala técnica legislativa; c) una incidencia sobre los derechos fundamentales que "va más allá" de la mera reproducción, sin que la Sentencia explique en qué consiste ese plus o "ir más allá"; si bien aclara que tales previsiones tendrán la eficacia señalada en el párrafo c) anterior... es decir, la eficacia de directrices, objetivos o mandatos a los poderes públicos autonómicos.

Creemos que la distinción entre "regulación" e "incidencia" (cuya vocación delimitadora a nadie escapa) no tiene la claridad necesaria para dar base a un reparto de los papeles entre el Estado y las Comunidades Autónomas en orden a disciplinar el tratamiento de los derechos fundamentales. Examinemos los supuestos posibles:

a) La simple reproducción. Este es el supuesto clave y básico para la Sentencia. Hay que entender, siguiendo el propio tenor del Fto. Jur. 15.d) antes transcrito, que se trata de la mera repetición, o sea, la pura transcripción ad pedem literae del derecho fundamental, ya que la Sentencia pone la frontera entre este supuesto y todo lo que "va más allá" de él. Es importante dejar marcada esta frontera porque de ella resulta que si un Estatuto de Autonomía se limita a repetir fielmente un derecho fundamental, estará efectivamente formulando un derecho que, lógicamente, trae causa de la propia Constitución y tiene la fuerza de obligar y demás características que son propias de los derechos fundamentales (art. 53.1 CE) ${ }^{124}$, ya que en tal supuesto no es el Estatuto la norma creadora del derecho sino que se hace eco del mismo. El profesor MUÑOZ MACHADO equipara a la reproducción textual "los desarrollos mínimos de orden lógico o sistemático que ayudan a alumbrar nuevos derechos que cabe entender comprendidos en otros que la Constitución consagra expresamente", interpretación razonable que cabría suscribir, pero que la STC $247 / 2007$ ha dejado sin sustento ya que su dicción al respecto es terminante. La cuestión es de suma importancia pues según la Sentencia, si el Estatuto no se limita a calcar sino que "va más allá", entonces el derecho proclamado, aun-

124 En este sentido, BIGLINO CAMPOS, P., "Los espejismos..." en Derechos, deberes y principios..., cit., afirma con toda razón que la reiteración en el Estatuto de los derechos, principios y deberes que ya están proclamados en la Constitución no añade un mayor grado de protección (pág. 53). MUÑOZ MACHADO también considera que los derechos tienen la condición de derechos fundamentales si reproducen o explicitan los que aparecen declarados en la propia Constitución, Tratado..., II, pág. 730. 
que pueda identificarse con un derecho fundamental de la Constitución o pueda subsumirse en él, no será ya un derecho sino que se habrá convertido ipso iure en una directriz, objetivo o mandato a los poderes públicos autonómicos, conclusión ésta que la Sentencia no motiva en absoluto, pese a que tendría mucho que motivar. Seguramente la razón subyacente haya sido la de abortar de raíz las presuntas extralimitaciones contenidas en los Estatutos, rebajando el valor de todo lo que no sea una repetición pura e indiscutible.

Pues bien, dicho lo anterior hay que señalar que en los nuevos Estatutos de Autonomía esa supuesta fiel reproducción de derechos constitucionales brilla por su ausencia ${ }^{125}$ con lo cual la Sentencia especula sobre una hipótesis inexistente hasta el momento y que será difícil que se produzca en el futuro. En efecto, ningún Estatuto se limita a transcribir preceptos constitucionales, lo que resulta además lógico habida cuenta la dinámica visible en los Estatutos tendente a descubrir facetas de los derechos que no se encuentran explicitadas en el texto constitucional. Todos los Estatutos adjetivan, aclaran, diversifican los derechos fundamentales que en la Constitución están formulados con la concisión que es propia de un texto de tal categoría; y si en algún caso aislado algún precepto estatutario se acerca a repetir la dicción de un derecho constitucional -por ejemplo la igualdad- es porque constituye la cabecera de un séquito de derechos vinculados al principio de igualdad que se formulan como variantes o modalidades del mismo (igualdad entre hombres y mujeres, no discriminación a los inmigrantes, respeto a la diversidad religiosa, etc.). Así, la paradoja final a que conduce la doctrina de la Sentencia 247/2007 es la siguiente: niega que los derechos proclamados en los Estatutos que se relacionen con derechos fundamentales sean derechos (a no ser que se trate de la más pura repetición de la fórmula utilizada por la Constitución) y niega también, como se verá más adelante, que constituyan verdaderos derechos las declaraciones de derechos sobre materias ordinarias, esto es, las ajenas a los derechos fundamentales y las libertades públicas. Y pese a estas rebajas tan sustanciales, la Sentencia seguirá haciendo gala de encontrarse inscrita en una línea de apertura a los contenidos estatutarios.

\footnotetext{
125 Con toda razón, APARICIO WILHELMI y PISARELLO señalan que "no es exacto que los estándares de tutela recogidos en las declaraciones estatutarias sean una simple repetición de los consagrados en la Constitución... no son pocos los que al especificar derechos constitucionales clarifican su contenido y su exigibilidad tanto frente a los poderes públicos como, eventualmente, frente a otros particulares", "El reconocimiento de derechos, deberes y principios..." en El Clip, cit., pág. 11.
} 
b) El desarrollo. Tan cierto es que un derecho fundamental sólo puede ser regulado en sus aspectos esenciales por el Estado, como que las Comunidades Autónomas, si tienen competencias asumidas sobre la materia, pueden desarrollar sus aspectos complementarios o secundarios, tales como cuestiones de organización y de procedimiento. Pero los Estatutos, de hecho, no se dedican a desarrollar estos aspectos no esenciales, porque no es ésta su función típica. Quede no obstante apuntada esta posibilidad teórica.

c) La especificación de derechos fundamentales. A diferencia del desarrollo, la especificación no tiene por objeto la regulación de los aspectos organizatorios o procedimentales, sino la revelación de una faceta del derecho mismo y, por tanto, sí puede afectar a su identidad e incluso llegar a distorsionarla si se trata de una especificación irregular o falsa especificación ${ }^{126}$. Se quiere decir que la verdadera especificación tiene naturaleza declarativa y es lícita, pues sólo pone al descubierto versiones o proyecciones especiales del derecho fundamental que se hallan ínsitas en el mismo. La especificación declara o interpreta rectamente lo que está contenido potencialmente en el enunciado de un derecho constitucional y, por tanto, lo redescubre y pone a la vista.

Formalmente, la especificación no supone la reproducción del derecho fundamental pero materialmente se le asemeja puesto que, en puridad, tanto una como otra no añaden ningún novum al precepto constitucional. Así, cuando los nuevos Estatutos de Autonomía diversifican el principio constitucional de igualdad proclamando el derecho a la no discriminación, no ya por razón del sexo -explícitamente contemplado en el artículo 14 CE- sino por razón de la "orientación sexual" (Estatutos Islas Baleares y Andalucía), están sacando a la luz una faceta de la regla de la igualdad que se encuentra materialmente comprendida, sin forzamiento interpretativo alguno, en el artículo $14 \mathrm{CE}$ aunque éste no la haya explicitado. Y lo mismo ocurre con los preceptos estatutarios que proscriben el maltrato doméstico, pacíficamente subsumibles en el artículo $15 \mathrm{CE}$; o los que diversifican el derecho a participar en asuntos, funciones y cargos públicos (art. $23 \mathrm{CE}$ ) en una serie de modalidades ("promover

\footnotetext{
${ }^{126}$ Como puede deducirse del texto no utilizamos la idea de especificación en el sentido con el que BOBBIO se refiere al proceso de especificación de los derechos, lo que PECES-BARBA llama proceso de concreción; ambos, para aludir al fenómeno que viene a añadir a la evolución histórica de los derechos humanos un nuevo efecto expansivo que se produce tanto sobre los sujetos o titulares de los derechos como sobre su contenido". PECES- BARBA MARTÍNEZ, G., Curso de Derechos Fundamentales... cit. pág. 180 y ss.
} 
y presentar iniciativas legislativas", "participar activamente en la vida pública", "derecho a ser tratados por las Administraciones de forma imparcial y objetiva"...) que encuentran indiscutible acomodo en dicha norma constitucional. Y lo mismo cabe decir de otro derecho social de carácter fundamental como el derecho a la educación (art. 27), susceptible de muchas especificaciones.

Desde luego, es posible que los Estatutos contengan enunciados de derechos pretendidamente especificativos de derechos constitucionales que puedan suscitar dudas sobre si en realidad están creando derechos nuevos no subsumibles en los derechos constitucionales; baste citar al respecto supuestos actualmente en debate por la opinión pública, tales como los derechos a la muerte digna, paridad, ordenación lingüística, etc. Sin entrar aquí en estas controversias, por no ser necesario, lo que se quiere indicar es que es posible que algún derecho estatutario, aun proclamado bajo la supuesta cobertura de un derecho fundamental -del que sería una "especificación"-, no sea en rigor subsumible en éste. Por ello, no cabe minimizar el peligro que pueden conllevar estas especificaciones, dada la posibilidad de que exista la tentación de "estirar" el derecho fundamental hasta el extremo de crear, al socaire de la Constitución, un derecho realmente nuevo y distinto al que rige para el resto de los territorios. En suma, el riesgo, advertido por Lorenzo MARTÍN RETORTILLO, de una diversificación subrepticia de derechos fundamentales que provoque la ruptura de la unificación, felizmente conseguida por la Constitución, como condensado de los principios proclamados en los numerosos Tratados y Declaraciones internacionales y comunitarias que el autor cita ${ }^{127}$. Pero ese riesgo, cierto en verdad, no supone en sí mismo ilicitud, por lo que todo se reduce a un problema de control de adecuación de los Estatutos a la Constitución, control que deben ejercer las instituciones previstas para ello.

Ciertamente, no es admisible nada que sea contrario a un derecho fundamental, aunque provenga de un Estatuto de Autonomía ${ }^{128}$. Y para que

127 "Derechos humanos y Estatuto de Autonomía" en Revista Aranzadi del TC, núm. 3, 2006, pág. 209.

${ }^{128}$ APARICIO WILHELMI Y PISARELLO señalan la posibilidad de que "las Comunidades Autónomas, en el ámbito de sus competencias, especifiquen e incluso amplíen, aunque sin contradecir, los derechos, deberes y principios contemplados en la CE"; y ello porque como normas institucionales básicas "ostentan una naturaleza cuasi-constitucional que las convierte, junto a la propia CE, en elemento insoslayable de la Constitución territorial del Estado", "El reconocimiento de derechos..." en El Clip, cit. Por su parte, MUÑOZ MACHADO afirma que la reproducción o es- 
sea válido el enunciado de una ley autonómica o de un Estatuto no basta, a nuestro juicio, con que no "contradiga" el derecho fundamental sino que tiene que estar en línea o en consonancia con él. En suma, no se pueden crear derechos que no tengan cabida en el derecho fundamental que la Constitución ha configurado, ni al margen del mismo, aprovechando resquicios que pudieran ser calificados como lagunas susceptibles de relleno; cosa distinta es la "especificación" en el sentido antes referido. Hay que entender que los derechos fundamentales diseñados por la Constitución acotan un área de la vida individual, social o política tanto en sentido positivo como negativo, de tal modo que queda integrada en cada formulación no sólo lo que la Constitución dice sino también lo que silencia, razón por la cual la ley ordinaria -o el Estatuto- no puede invadir esa área acotada so pretexto de rellenar huecos, ampliar el derecho fundamental o introducirle mejoras ${ }^{129}$. Por consiguiente, no sólo serían nulas las especificaciones -falsas- que limitasen o redujesen derechos fundamentales -como viene a decir el art. 37.4 del Estatuto de Cataluña, redacción dada en el Congreso de los Diputadossino también aquellas que al ampliarlos los distorsionen o desfiguren. Todo esto sería un ataque a la Constitución que el Estado debe vigilar e impedir con todo celo pues en ello va en juego la preservación del signo más claro e indiscutible de la unidad, máxime teniendo en cuenta el debilitamiento que han venido experimentando otros mecanismos constitucionales que en principio parecían llamados a cumplir ese papel integrador. En suma, no caben tibiezas ni complacencias en cuanto al rol que a cada institución le

pecificación de valores, principios o derechos fundamentales podrá cuestionarse en razón a su eficacia, pero si no tienen determinaciones contrarias a la Constitución tienen el mismo valor que los preceptos constitucionales que reproducen, Derecho público....", cit. pág. 372.

${ }^{129}$ En esto venimos a coincidir en buena parte con MARTÍNEZ LÓPEZ-MUÑIZ para quien "la inclusión de 'cartas' sobre estos derechos y libertades no podrían, en rigor, sino repetir las formulaciones constitucionales, sin determinarlas, modificarlas, modalizarlas o desarrollarlas"; pero a nuestro juicio sí cabe, amén del desarrollo autonómico de los aspectos no esenciales, la especificación de la que hablamos en el texto. Vid. MARTÍNEZ LÓPEZ-MUÑIZ, J. L., "Límites constitucionales generales del contenido de las reformas estatutarias" en La reforma de los Estatutos de Autonomía, Junta de Castilla y León, Valladolid, 2003, pág. 106. Contrariamente, enfocan la cuestión de otro modo APARICIO PÉREZ, M. A. y BARCELÓ i SERRAMALERA, M., quienes haciendo referencia a algunos enunciados estatutarios definidos como derechos, tales como el derecho al testamento vital, a vivir con dignidad el proceso de la muerte, a la elección de la propia orientación sexual, lo que se produce es "un reconocimiento de derechos de nuevo cuño, lo que emerge es nueva categoría de normas iusestatutarias con rango y garantías propias". Como se ve, admiten la creación de derechos, como de nueva planta, aun en estas materias que tienen "sustancia" de derecho fundamental constitucional. "Los Derechos Públicos Estatutarios" en Derechos y principios rectores..., cit. pág. 33. 
compete jugar cuando se trata de derechos fundamentales. Si el Gobierno central o las Cortes Generales no son beligerantes contra ello, tendrá que serlo el Tribunal Constitucional.

De todo lo anterior se concluye que no es lícito que los Estatutos incorporen enunciados que alteren derechos y deberes fundamentales pero sí que puedan hacer especificaciones porque éstas, como ya se ha dicho, no son más que declaraciones potencialmente contenidas en el derecho fundamental, razón por la que éste no sufre sino que se enriquece en su apariencia externa y operatividad práctica. Obvio es decir que de no ser así todas las tablas de derechos integradas en los Estatutos serían inconstitucionales al menos en parte.

Pues bien, si lo anterior es cierto, no se entiende por qué la STC 247/2007, en su Fto. Jur. 15 antes transcrito, sin una motivación debidamente explicitada, degrada a la condición de meros principios u objetivos todos los enunciados estatutarios relativos a derechos fundamentales, salvo que sean un puro calco de la Constitución, porque ello significa la destrucción de la labor especificadora que tanto ha contribuido a visualizar las potencialidades de la Carta Magna y a difundir su imagen ante los ciudadanos como un bien cercano y protector.

b) Sobre la petrificación y sustracción al juego democrático que puede suponer la inclusión de derechos en los Estatutos.

Este es el argumento de fondo más potente del presente debate. En palabras de FERRERES COMELLA, desde el momento en que se introduce un catálogo de derechos en una Constitución, el legislador se ve sujeto a límites; ciertas cosas que antes podía hacer ya no son lícitas (o ciertas cosas que podía no hacer devienen ahora obligatorias), añadiendo la precisión de que aunque los derechos incluidos en un Estatuto no son "fundamentales" hacen el mismo efecto -por su rigidez- puesto que su contenido se impone al legislador ${ }^{130}$. En el mismo sentido DÍEZ-PICAZO ha señalado que introducir declaraciones de derechos en los Estatutos supone definir el terreno del proceso político democrático, de tal modo que una opción política es legítima si la hace el legislador y no lo es si la hace un Estatuto, pues esto significa que el legislador autonómico ya no podrá reconsiderar dicha opción. En España -dice el autor-

130 "Derechos, deberes y principios...", cit. págs. 17 y 22. 
el terreno del proceso político democrático viene fijado por el Título I de la Constitución y no se puede "privar a los ciudadanos por vía estatutaria de algo que tenían por vía constitucional. Si no existieran esas normas estatutarias declarativas de derechos, se aplicaría sólo el Título I de la Constitución y los ciudadanos -o sus representantes- podrían debatir y votar sobre más cosas" ${ }^{131}$. FERRERES COMELLA ha abundado en lo anterior con un argumento de otro corte, señalando la inconveniencia de que el constituyente, en este caso el "estatuyente", se precipite sin haber sopesado previamente el verdadero consenso existente en la sociedad sobre asuntos tan discutibles y delicados como el derecho a vivir con dignidad el proceso de la propia muerte, la laicidad de la enseñanza pública, la igualdad de las diferentes uniones de pareja, la consecución de la "paridad" -idea distinta del principio de igualdad real y efectiva-algunos aspectos relativos a los derechos y deberes lingüísticos que no forman parte del consenso político básico, etc. En suma, asuntos que no son nada "neutrales" y sin embargo han quedado congelados en el Estatuto de Cataluña, que es el que el autor toma como referencia ${ }^{132}$.

Contra el fallo de la STC 247/2007 hay votos particulares de magistrados que están en línea con la doctrina que acaba de citarse. Aparentemente resulta ello extraño pues la Sentencia, como ya hemos apuntado, niega a la postre la licitud de las declaraciones de derechos sustantivos en favor de los ciudadanos (al menos, del grueso de los derechos subjetivos de genuina creación autonómica), pero como aquélla se mueve en el plano de la confusión entre lo que genéricamente declara y lo que efectivamente resuelve, es por lo que propicia la formulación de ciertas "discrepancias" que inciden precisamente en el dato de la rigidez de la reforma de los Estatutos ${ }^{133}$. En suma, para la doc-

131 DÍEZ-PICAZO GIMÉNEZ, L. M., “¿Pueden los Estatutos...?”, cit., págs. 71 y 72. Análogamente, esgrime el argumento de la petrificación en contra de la inclusión en los Estatutos de objetivos, fines o programas, AGUADO RENEDO, C., El Estatuto de Autonomía ... cit., pág. 324. Por su parte, señala los inconvenientes RUIZ-RICO RUIZ, G., entre ellos el de obstruir el posible mecanismo estatal ex art. 149.1.1 ${ }^{\text {a }}$ para modificar el alcance de unos derechos que se encontrarían "blindados" por encontrarse en un Estatuto de Autonomía. "Derechos Sociales y reforma de los Estatutos de Autonomía: el derecho a la vivienda”, cit., págs. 85-86.

${ }^{132} \mathrm{Y}$ el autor añade datos de los entresijos del proceso de formación del Estatuto -los interna corporis- que acreditan la ausencia de acuerdo básico de las distintas fuerzas políticas catalanas en torno a estos valores fundamentales. FERRERES COMELLA, V., "Derechos, deberes y principios..." cit., págs. 24 y ss.

133 El voto particular del magistrado don Javier DELGADO BARRIO resalta el dato de la rigidez como determinante para entender el principio restrictivo que ha de presidir el contenido del 
trina antes referida lo que debe caracterizar al Estado Social es precisamente su carácter abierto y flexible, mutante en virtud del pluralismo político, lo que resulta aún más procedente en momentos de crisis económica ${ }^{134}$.

Contra esta postura se han alzado otras opiniones que, o bien tratan de minimizar la trascendencia de esta congelación, o bien hacen de ella virtud, poniendo en este último caso el acento en la "función transformadora" de la sociedad que supuestamente han de cumplir los Estatutos. Así, CAAMAÑO afirma que son posibles otros consensos aparte del acaecido para fraguar el Título I de la Constitución y que lo contrario significa "abrazar el Estado mínimo de NOzIC y abjurar de todo republicanismo democrático"135. Más incisivamente, se ha señalado que la decisión de reconocer derechos, y con ello, límites y vínculos al legislador autonómico ordinario es una decisión democráticamente asumida por el poder estatuyente (compuesto por los Parlamentos autonómicos, las Cortes Generales y en algunos casos el propio cuerpo electoral de las Comunidades Autónomas) por lo que resulta inconsistente cues-

Estatuto. Dice así: "Sólo puede ser contenido lícito de un Estatuto, dado el fondo paccionado de éste, lo que es objeto de la competencia conjunta del Estado y de la Comunidad Autónoma, que es la materia reservada al Estatuto, esto es, la integrada por las determinaciones expresamente previstas en la Constitución y, en su caso, por un contenido adicional o conexo. Esto es lo que puede quedar legítimamente 'congelado' en virtud de su inclusión en el Estatuto, dada la rigidez de la reforma de estos". "Toda otra materia ajena a la competencia conjunta establecida por la Constitución, de incluirse en el Estatuto, vería alterado su régimen jurídico pues ya no podría ser modificada por la decisión unilateral del ente competente, que habría de contar con la voluntad del otro". La posible inclusión del contenido adicional ha de cumplir dos requisitos: $1^{\circ}$. Ha de tener una conexión con la materia constitucionalmente reservada al Estatuto; $2^{\circ}$. Ha de ser complemento adecuado de la regulación estatutaria de esa materia, adecuación ésta que ha de entenderse en el sentido estrictamente preciso para que el Estatuto pueda cumplir la función que la Constitución le encomienda. Por su parte, el voto particular del magistrado Sr. RODRÍGUEZ ZAPATA incide sobre el dato de la rigidez del Estatuto, diciendo: "Ese carácter de fuente de contenido legítimo ambiguo e impreciso y de pétrea fuerza de resistencia, en cuanto a su posibilidad de reforma, produce unos efectos indeseables en nuestro sistema de fuentes que, hacia arriba, deconstruye las competencias constitucionales del Estado y, hacia abajo, limita en forma grave el funcionamiento democrático de las Comunidades Autónomas. En efecto, cada vez que una mayoría ocasional de partidos autonómicos logre el plácet de las Cortes Generales, podrá petrificar en una reforma del respectivo Estatuto derechos, principios, mandatos o directrices que vinculen a mayorías democráticas futuras".

${ }^{134}$ LÓPEZ GONZÁLEZ, J. L., "Reflexiones sobre los derechos sociales y su eficacia jurídica" en Revista General del Derecho, núm. 628-629, 1997, pág. 160.

135 CAAMAÑO DOMÍNGUEZ, F. M., "Sí, pueden..." cit., pág. 39. 
tionar el carácter formalmente democrático de tal decisión; pero además -se dice- la congelación de derechos civiles, políticos y sociales en los Estatutos reduce los márgenes de arbitrariedad de los poderes públicos y refuerza la autonomía de las personas frente al propio poder, central o autonómico, legislativo o ejecutivo, público o privado ${ }^{136}$. En esta misma línea se ha dicho que los derechos sociales, que tan estrechamente están relacionados con los derechos individuales, forman parte de esa dimensión sustancial que limita y condiciona la decisión democrática y que su aportación resulta importante para que la democracia formal se lleve a cabo en mejores condiciones o con una mayor autenticidad; se trata de tener una mejor democracia ${ }^{137}$, lo que conduce a una concepción del Estatuto no sólo como elemento regulador sino como un arma de transformación cuya misión no es solamente la de integrar el consenso social existente sino impulsar la realidad que pretende regular ${ }^{138}$.

Aun dentro de esta corriente defensora de la inclusión de derechos en los Estatutos MARC CARRILLO no deja de tener en cuenta el peligro que conlleva la petrificación y por ello postula la fijación de esos derechos en el Estatuto en sus aspectos más genéricos, pues de otra forma podría vulnerar -dice- el principio constitucional del pluralismo político y la libertad de opciones ${ }^{139}$, opinión que nos parece discutible ${ }^{140}$.

136 APARICIO WILHEMI, M. y PISARELLO, G., "El reconocimiento de derechos..." en El Clip, cit. pág. 4. En análogo sentido, AGUDO ZAMORA, M. J., "Derechos sociales y políticas públicas en la reforma del Estatuto de Autonomía para Andalucía, Nuevas políticas públicas. Anuario multidisciplinario...”, cit. pág. 140.

137 SASTRE ARIZA, S., "Hacia una teoría exigente de los derechos sociales" en Revista de Estudios Políticos, núm. 112, 2001, pág. 262.

138 Así lo defiende EXPÓSITO, E., "La regulación de los derechos...” en Revista d'Estudis Autonòmics $i$ Federals, cit., pág. 55.

139 "Los derechos, un contenido..." en REDC, cit., págs. 63 y 64. Partiendo de esta premisa, el profesor CARRILLO, refiriéndose al nuevo Estatuto catalán destaca el carácter genérico de la inmensa mayoría de sus prescripciones, de lo que concluye que es razonable no apreciar vicios de inconstitucionalidad en esta opción del legislador estatuyente. De igual manera, Enriqueta EXPÓSITO arguye que "en la formulación estatutaria de los derechos se ha utilizado no sólo una redacción lo suficientemente amplia como para permitir todas las opciones políticas en su desarrollo -al igual que sucede con la mayoría de los derechos constitucionales o internacionalmente proclamados-, sino que además se hace una constante remisión al legislador autonómico para que los regule y desarrolle más allá de los mínimos estatutarios", "La regulación de los derechos...” cit., pág. 164.

${ }^{140}$ A nuestro juicio, la licitud de la inclusión de los derechos en los Estatutos nada tiene que ver con la eventualidad de que estos derechos aparezcan regulados con mayor o menor precisión. 
No cabe negar que se trata de un tema plagado de claroscuros donde los inconvenientes de la petrificación se palpan en relación con las normas que establecen deberes -normas odiosas- y con los derechos ideológicamente controvertidos. Podría decirse que éste es un coste que el sistema paga a cambio del bien que conlleva la fijación de numerosos objetivos positivos -normas favorables- a cumplir por los poderes autonómicos y que por ello cuentan con el consenso de la inmensa mayoría de la ciudadanía. Por otra parte, no cabe marginar el dato de que esa petrificación estatutaria en una gran medida no opera ex novo o en el vacío sino sobre un tejido muy espeso de normas preexistentes en funcionamiento, lo cual es un factor indudablemente desdramatizador, como lo es el hecho de que la petrificación no es al cabo un suceso definitivo que socave el núcleo esencial del juego democrático sino una situación reversible, al menos teóricamente, lo cual parece suficiente.

La STC 247/2007, no se encara al problema de la congelación cuando se decanta por la interpretación amplia del artículo 147.2 CE (FFJ 11 y 12); no obstante, en otra parte de ella refiriéndose a los contenidos del Estatuto deja dicho que éste "es obra de un legislador democrático y que la regulación que realiza... es vehículo de la voluntad de autogobierno de un determinado territorio y expresión de la voluntad del Estado" (Fto. Jur. 6, in fine).

c) Otra línea argumental. Los Estatutos son aprobados por leyes orgánicas del Estado. ¿Pueden éstas crear desigualdades entre los españoles?

Otra objeción importante esgrimida en contra de la formulación de derechos estatutarios se plantea en los términos siguientes: los Estatutos de Autonomía y sus reformas exigen la aprobación final mediante ley orgánica, lo

El problema se circunscribe a si esa inclusión es legítima o no. Aceptada que sea la legitimidad de la inclusión y, por tanto, la congelación del derecho de que se trate, resulta ya indiferente, por pura coherencia, que el Estatuto regule el derecho con mayor o menor amplitud, o lo que es lo mismo, deje mayor o menor margen al juego de las fuerzas políticas. Es más, si verdaderamente se está conforme en que es legítimo petrificar una determinada opción política incluyéndola en el Estatuto, lo que debe postularse es que el estatuyente haga el esfuerzo de precisar su regulación lo más posible evitando ambigüedades y remisiones al legislador salvo en la medida mínima necesaria para completar aspectos de difícil o imposible regulación estatutaria. En suma, si el estatuyente decide consagrar en el Estatuto un auténtico derecho,-admitida que fuere la legitimidad de tal operación-, lo que tendría que hacer en consecuencia y sin rodeos es definirlo derechamente sustrayéndolo de los avatares de un juego político que podría dar al traste con lo que se ha querido congelar. En definitiva, cuando se trata de un derecho no cabe razonar como si fuera un principio rector, pues la vocación de cualquier derecho proclamado no es otra que la de su concreción por la vía más rápida e inmediata posible. 
que significa que no dimanan sólo de la voluntad del electorado y de los órganos de la Comunidad Autónoma sino también de la voluntad de las Cortes Generales. Siendo esto así, admitir que los Estatutos puedan recoger declaraciones de derechos es tanto como admitir que las Cortes Generales pueden dar unos derechos a unos españoles y otros derechos a otros españoles ${ }^{141}$. Lógicamente, las razones de esta proposición se hacen más incisivas cuanto más quede acentuado el dato de que el Estatuto es una ley del Estado y que no cabe distinguir entre el Estatuto y la ley orgánica que lo aprueba ${ }^{142}$.

No es otra la tesis que sostienen varios magistrados discrepantes del fallo de la STC 247/2007, quienes enfatizan sobre la diferencia existente entre la diversidad en el tratamiento de los derechos que puedan producir los parlamentos autonómicos en su función legiferante y la que pueda derivar directamente de los Estatutos de Autonomía ${ }^{143}$.

${ }^{141}$ DÍEZ-PICAZO GIMÉNEZ, L. M., “¿Pueden los Estatutos...?”, cit., pág. 72.

142 En este sentido, AGUADO RENEDO, C., tras reconocer las especialidades procedimentales que se dan respecto a las leyes orgánicas que aprueban los Estatutos, concluye afirmando que no puede hablarse con propiedad del Estatuto de Autonomía negando a éste su carácter de ley orgánica, por muy matizada que sea esa negación. El Estatuto de Autonomía..., cit., pág. 210. En la misma línea, MUÑOZ MACHADO, S., quien niega que se trate de una ley paccionada al ser sólo una la voluntad que concurre para su aprobación: la de las Cortes Generales, Tratado..., II, cit., págs. 687 a 693. Asimismo, sobre el decisivo papel de las Cortes Generales, BLANCO VALDÉS, R., "¿Quién reforma los Estatutos de Autonomía? en El Estado Autonómico. Integración, solidaridad y diversidad, Vol. I (Coord. Vidal Beltrán y García Herrera), Colex-INAP, 2005, págs. 357 y ss.

143 Así, el magistrado don Vicente CONDE MARTÍN DE HIJAS en su voto particular pone de relieve que es el Estado, como instancia única, el que aprueba los distintos Estatutos "y es a partir de ese inexcusable elemento unificador como debe analizarse si es compatible con la exigencia del artículo 139.1 CE que el Estado haga declaraciones de derechos no referibles a la totalidad de sus ciudadanos, sino sólo a los residentes en el territorio de una Comunidad Autónoma. Mi criterio -dice el magistrado- es que el artículo 139.1 CE veda esa posibilidad". Y añade la siguiente reflexión: "La consagración del derecho de los ciudadanos en una norma estatal del rango que corresponde a un Estatuto de Autonomía, Ley Orgánica, obligará al respeto de ese derecho no ya sólo al legislador autonómico, sino a cualquier eventual norma estatal de rango inferior, y limitará en la misma medida la plena disponibilidad del legislador estatal, y no sólo al autonómico, al ejercer sus propias competencias. Y ahí es precisamente donde radica la dificultad para poder cohonestar con el artículo 139.1 esas declaraciones de derechos". En el mismo orden de ideas, el magistrado disidente Sr. DELGADO BARRIO destaca que el acto formal de que todos los Estatutos de Autonomía se aprueban por un mismo legislador, a diferencia de las leyes autonómicas, "tiene muy relevantes consecuencias para el principio de igualdad [...] hemos declarado -STC 319/1993 de 27 de octubre, FJ 5- que no es admisible que las normas establezcan diferenciacio- 
De contrario, se arguye, como es lógico, la sustantividad del Estatuto de Autonomía frente a las demás leyes orgánicas que aprueba el Estado, lo que permite evitar, así lo afirma MARC CARRILLO ${ }^{144}$, una absoluta identificación jurídica entre el Estatuto como norma institucional básica y el instrumento normativo que es la ley orgánica a la que formalmente se refiere la CE. A esta premisa de partida se añadirá el dato de que el Estatuto forma parte del bloque de la constitucionalidad; que tiene una superioridad normativa sobre las leyes de cualquier procedencia, ya sean del Estado o de las Comunidades Autónomas; y sobre todo que es fruto de la concurrencia de dos voluntades legislativas en un proceso de carácter paccionado ${ }^{145}$, lo que enfatiza el papel de la Comunidad Autónoma en la autoría del Estatuto. Por su parte CÁMARA VILLAR pone agudamente el acento en la idea de que sólo en abstracto cabe hablar de "el mismo legislador" que aprueba todos los Estatutos, mas no en relación con cada Estatuto en concreto, dada la significación de esta norma en la articulación del pluralismo territorial y su carácter paccionado; en suma, su funcionalidad en un Estado compuesto ${ }^{146}$.

CAAMAÑO opone una argumentación más frontal pues incluso prescinde de la idea del carácter paccionado del Estatuto. Así, sin hacer cuestión del hecho de que se trata de un producto de las Cortes Generales, estima que en un Estado políticamente descentralizado como el nuestro "es perfectamente normal que las Cortes Generales varíen su postura en función del interlocutor con el que mantenga su diálogo normativo [...]; gestionar la diferencia no es incurrir en la arbitrariedad, sino cumplir razonablemente con una obligación constitucional $^{147}$ ". Y en esta misma dirección, CABELLOS ESPIÉRREZ realza

nes no razonables o arbitrarias entre los sujetos a un mismo legislador". Así, los Estatutos no son el ámbito normativo adecuado para la inclusión de derechos que han de implicar diferencias ya que esto ha de estar inspirado en un criterio "profundamente restrictivo". En el mismo sentido, el voto particular del magistrado Sr. GARCÍA CALVO pone el acento en la diferencia de que los derechos estén reconocidos en las leyes autonómicas o en los Estatutos mismos.

144 "Los derechos, un contenido constitucional..." en REDC, cit. pág. 51.

145 Ibidem, págs. 51 a 53.

146 "Los derechos estatutarios no han sido tomados en serio (A propósito de la STC 247/2007, de 12 de diciembre, sobre el Estatuto de Autonomía de la Comunidad Valenciana)". Estudio elaborado para su publicación en la Revista Española de Derecho Constitucional que su autor, Gregorio CÁMARA, me ha permitido consultar antes de su publicación. Un trabajo excelente, lleno de certeras reflexiones.

147 CAAMAÑO DOMÍNGUEZ, F. M., "Sí pueden..." en REDC, cit., págs. 44-45. 
el dato de que el Estatuto es una norma estatal, precisamente para poner de relieve que es el propio Estado quien quiere que sea distinto el contenido del Estatuto en determinada Comunidad Autónoma; y más, que con ello el propio Estado vincula sus competencias a lo que él ha establecido en la norma estatutaria $^{148}$.

La STC 247/2007 no razona sobre este orden de consideraciones, o mejor puede decirse que se lo ha evitado, al haber negado la premisa mayor, esto es, que los derechos proclamados en los Estatutos sean verdaderos derechos. Pero el tema -sí puesto de relieve por los votos particulares- es importante y merece una reflexión adicional.

En efecto, vemos cómo es realzado el argumento de que el Estatuto es una norma del Estado, con finalidades distintas e incluso contrapuestas. Ahora bien, si se desciende desde la teoría a lo puramente fáctico, la percepción general sobre el papel jugado por las Cortes Generales en relación con los nuevos Estatutos no ha sido precisamente el de un coautor activo y, por tanto, promotor de desigualdades entre Estatutos, sino más bien como un controlador negativo, ciertamente menguado, limitado a defender la Constitución de los excesos estatutarios inadmisibles. Pero, en cualquier caso, las cuestiones relativas a la igualdad se disuelven en la interpretación que la Sentencia 247/2007 hace de los artículos 138.2 y 139.1 CE. Con tal hermenéutica, el problema de la desigualdad interterritorial pierde relevancia así como la acusación al Estado de generar esas diferencias, conclusión ésta muy extrema que podría haberse dulcificado con una interpretación más equilibrada del artículo 139.1 CE, según expusimos supra en epígrafe dedicado a analizar este precepto $^{149}$.

d) De nuevo sobre la sujeción a la potestad del Estado ínsita en el artículo 149.1.1 ${ }^{a} \mathrm{CE}$.

Ya quedó fijada supra (IV.3.E) la significación de este precepto en cuanto a las leyes autonómicas en general, plano éste en el que la Sentencia 247/2007 sitúa su discurso. Ahora, puestos a señalar el alcance de esa potestad estatal en

\footnotetext{
148 "La relación derechos-Estado autonómico en la Sentencia 247/2007...", cit. pág. 140. Es ocioso señalar la discutibilidad de tal opinión.

149 Vid. supra epígrafe IV.3.C)
} 
su relación concreta con los Estatutos, hay que decir, paradójicamente, que la cuestión se simplifica e incluso se esfuma como problema y ello por mor de la impotencia de esas eventuales bases estatales para percutir sobre los enunciados de derechos y principios que ofrecen los nuevos Estatutos, según resulta de la propia jurisprudencia constitucional.

En efecto, por un lado hay que tener en cuenta, de acuerdo con esa jurisprudencia ${ }^{150}$, que el específico campo sobre el que opera el artículo 149.1.1 $1^{\text {a }}$ es comprensivo no de cualquier derecho sino de los "derechos y deberes constitucionales", lo que equivale propiamente al contenido del Cap. II, Tít. I CE, contrayéndose además a las "posiciones jurídicas fundamentales", imprescindibles para garantizar una igualdad compatible con la heterogeneidad que es propia del sistema. Y por otro lado, hay que observar que la inmensa mayoría de los derechos, deberes y principios que se vienen insertando en los Estatutos caen fuera del radio de acción del artículo 149.1.1 ${ }^{\mathrm{a}} \mathrm{CE}$, bien porque se trate de enunciados totalmente nuevos sobre materias ajenas a la Constitución, bien porque son derechos que traen causa de principios rectores (Cap. III, Tít. I) a los que no alcanza la onda de ese instrumento estatal, según doctrina constitucional ya referida ${ }^{151}$. Quedarían, pues, sometidos, en principio, a los efectos de esa eventual normativa básica sólo los derechos y deberes estatutarios que son trasunto de los genuinos derechos fundamentales, bien porque los desarrollen o los especifiquen (o sea, porque "van más allá" de su mera reproducción literal, en la dicción de la STC 247/2007); pero como resulta que estos enunciados que "van más allá" son calificados por esta misma Sentencia como meros principios, según ya hemos visto, no parece proporcionado que el Estado se empeñe en movilizar su potestad ex art. 149.1.1 ${ }^{\mathrm{a}} \mathrm{CE}$ sólo para corregir enunciados de carácter principial, sin eficacia directa ni accionabilidad ante los Tribunales. De este modo, la potencialidad de dicho precepto queda reducida prácticamente a la nada (sólo a los enunciados que reproduzcan derechos fundamentales, sin repercusión sobre los derechos sociales proclamados en los Estatutos. Pero, además, hay que añadir, desde la realidad de las cosas, que resulta impensable y posiblemente ilícito en términos

${ }^{150}$ Son especialmente citables las SSTC 154/1988 de 21 de julio; 61/1997 de 30 de abril; 173/1998 de 23 julio; 37/2002 y las Sentencias que ésta cita; 133 y 135/2006, ambas de 27 de abril.

${ }^{151}$ Sobre este extremo puede verse SÁNCHEZ FÉRRIZ, R., "Derechos sociales y Comunidades Autónomas: los márgenes de las políticas autonómicas" en El Estado autonómico: Integración, solidaridad y diversidad, cit., Vol. I, págs. 498 y ss. 
constitucionales, que el Estado se inmiscuya, utilizando tal instrumento, en este mundo de los derechos sociales que es por excelencia el campo natural de las normas favorables, salvo, claro está, que éstas desfiguren o contraríen al alza o a la baja un derecho fundamental.

Teniendo en cuenta lo expuesto no parecen oportunas las consideraciones de teoría general sobre el artículo $149.1 .1^{\mathrm{a}}$ en las que se enfrasca la STC 247/2007 (ámbito en el que incide, concepto de "condiciones básicas", su diferencia con las "bases" o la "legislación básica"...), cuando lo verdaderamente esencial es lo que afirma como obligada consecuencia de la tesis central que la misma sostiene (esto es, que los derechos que proclaman los Estatutos no son verdaderos derechos); y lo que afirma es que el artículo 149.1.1 " $n o$ se proyecta sobre los derechos, principios o directrices estatutarios en sentido estricto, es decir, sobre los preceptos estatutarios de tal carácter que no reproduzcan los derechos constitucionales" (Fto. Jur. 17), solución ésta que supone a la postre una limitación al poder del Estado digna de una seria reflexión acerca de la bondad real de la citada tesis ${ }^{152}$. En efecto, si a la ya restringida interpretación del art. 139.1 CE -reducida su aplicación al ámbito intraterritorial, como expusimos supra, IV.3.C- se suma una también estricta interpretación del alcance del artículo 149.1.1 como mecanismo estatal de igualación, es evidente que quedan al descubierto espacios sin cubrir porque no resultan alcanzados por ninguno de esos dos mecanismos, lo que se acentúa por el hecho de la transformación de los derechos estatutarios en principios rectores, operación ésta que hace desaparecer la causa que permite al Estado, eventualmente, poner en práctica la garantía de las "condiciones básicas" en el ejercicio de los derechos.

\section{e) El argumento del derecho comparado.}

Es un hecho que en los Estados descentralizados, ya se trate de sistemas federales o de modelos más próximos al nuestro, las Constituciones de los Estados miembros o los Estatutos de las regiones contienen Cartas de derechos. Así lo ha destacado la doctrina en relación, señaladamente, con los Estados

\footnotetext{
152 La prueba más evidente de lo que decimos la brinda la propia Sentencia del Tribunal Constitucional 247/2007 cuando afirma que el artículo 17.1 del Estatuto valenciano objeto del recurso no puede friccionar con el artículo 149.1.1 ${ }^{\text {a }} \mathrm{CE}$ "pues no estamos ante un derecho constitucional por lo que, de acuerdo con nuestra reiterada doctrina... no cabe proyectar sobre el mismo la señalada regla constitucional'. (Fto. Jur. 20.b). Un análisis del artículo 149.1.1 a tras la STC 247/2007 en CABELLOS ESPIÉRREZ, M. A., "La relación derechos-Estado en la Sentencia sobre el Estatuto valenciano" cit. págs. 113 y ss.
} 
americanos de la Unión, los cantones de la Confederación Helvética o algunos Länder de la RFA ${ }^{153}$ y, desde luego, con los Estatutos italianos surgidos tras las reformas de la Constitución operadas en el período 1999-2001, especialmente los de las Regiones Toscana, Umbría y Emilia Romagna, por haber propiciado sendas resoluciones de la Corte Costituzionale (372, 378 y 379 de 2004) que sientan la doctrina que enseguida diremos.

No es extraño que en España los partidarios de las Cartas estatutarias de derechos hayan invocado en su favor esos precedentes ${ }^{154}$ y que los detractores se hayan esforzado en señalar las diferencias entre sistemas que hacen inviable el método comparatista. Una postura muy ponderada es la que sostiene MARC CARRILLO pues aun siendo partidario de la inclusión de esas Cartas, no da al derecho comparado más valor que el de un argumento complementario y no sustantivo, aunque, eso sí, válido como prueba de que la opción tomada por los nuevos Estatutos no es ninguna ocurrencia extravagante o un "delirio jurídico" 155.

Ciertamente, no es homologable nuestro sistema autonómico con los sistemas federales a estos efectos, como ha señalado DÍEZ-PICAZO ${ }^{156}$. Pero quizás menos aún puede ser el de Italia el modelo que deba traerse a colación para respaldar la legitimidad y sobre todo la eficacia de los derechos proclamados en nuestros Estatutos. En el sistema italiano el contraste de las soluciones -quizás la incongruencia- puede haber llegado al paroxismo. Por una parte, el sistema cuasi se federaliza; la Constitución de 1947 (art. 123), tras su reforma de 1999, ya permite, como destaca RAFFAELLE BIFULCO, que los nuevos

153 Señala Rainer HOFMANN que de las 16 Constituciones de los Länder, 10 tienen completos catálogos de derechos fundamentales propios. Para una visión general del sistema, vid. su "Federalismo y derechos en Alemania” en Estado compuesto y derechos de los ciudadanos, cit. págs. 13-28.

154 Señaladamente así lo hizo el Dictamen del Consejo Consultivo de la Generalidad de Cataluña núm. 269 de 1 septiembre de 2005 (Fto. Jur. III).

155 “Los derechos, un contenido constitucional...”, cit. pág. 65.

156 Así, recordando la postura al respecto de los profesores FERRERES COMELLA Y BIGLINO CAMPOS, señala que hay al menos dos importantes diferencias: una, en el Estado autonómico español no es la Constitución la que distribuye competencias sino los Estatutos de Autonomía; otra, que los Estatutos no son aprobados y reformados sólo por la correspondiente Comunidad Autónoma. Por el contrario, las entidades federadas poseen un poder constituyente residual sin más límite que no vulnerar la Constitución y el derecho federales, razón por la que pueden recoger declaraciones de derechos sin poner en cuestión el diseño del conjunto. “¿Pueden los Estatutos de Autonomía...?", cit., págs.. 66-67. 
Estatutos y sus contenidos estén sometidos al único límite de su "armonía con la Constitución"157; mas, por otra parte, la Corte Costituzionale, en las Sentencias antes citadas, ha negado valor jurídico alguno a las previsiones establecidas en los Estatutos en materia de derechos, pronunciamiento maximalista que no sólo afecta a las concretas cuestiones que fueron objeto de las Sentencias (derecho de sufragio de los inmigrantes, formas de convivencia distintas del matrimonio) sino a las nutridas tablas de principios y derechos contenidas ya en numerosos Estatutos, todas ellas provistas, según la Corte, "de naturaleza cultural o incluso política, pero ciertamente no normativa". Pues bien, esas tablas contienen enunciados nada baladíes tales como derechos a la información, a la salud, al trabajo, a la seguridad social, a la educación, a la asistencia, a la vivienda; derechos de los menores, ancianos, minusválidos... Todo esto, que es tanto, es sin embargo jurídicamente nada en el plano estatutario del sistema italiano. En suma, una solución parecida a la de la STC 247/2007 que ahora analizaremos, si no en la forma de plantear la cuestión -la Corte se limita a declarar la inadmisibilidad, sin entrar en el fondo-, sí en el resultado final al que se llega, con la diferencia de que nuestro TC no ha dado el paso de negar valor jurídico a ningún aspecto incluido en un Estatuto; así, en España los derechos estatutarios son convertidos en mandatos o principios; en Italia, en simple literatura. A la vista está que éste no es precisamente un modelo a tener en cuenta.

f) La tesis de la STC 247/2007: los derechos sustantivos ex novo que proclaman los Estatutos no son derechos, sino mandatos a los poderes públicos autonómicos.

En un epígrafe anterior ya quedó bosquejada la tesis central de la Sentencia 247/2007; toca ahora examinarla con el detalle debido. La idea fundamental es la siguiente: el Estatuto de Autonomía es fuente legítima e idónea para establecer verdaderos derechos públicos subjetivos, de eficacia inmediata, pero esto sólo en lo que atañe a "la denominación, organización y sede de las instituciones autónomas propias” (art. 147.2.c), no así en lo que se relaciona con las competencias asumidas (art. 147.2.d) en cuyo caso los enunciados estatutarios, cualquiera que sea la fórmula con la que se expresen, nunca tendrán la

157 "Estado Regional y Derechos en Italia" en Estado compuesto y derechos de los ciudadanos, cit. pág. 33. Sobre dicha cláusula véase también OLIVETTI, Marco "La Reforma del sistema autonómico italiano" en El Estado Autonómico: integración, solidaridad y diversidad, cit. págs. 47 y ss. Asimismo, ORTEGA SANTIAGO, C., "Los nuevos Estatutos de Autonomía de las Regiones italianas" en REDC núm. 78, 2006, págs. 43 y ss. 
naturaleza de un derecho subjetivo y siempre la de directrices, mandatos o principios rectores.

Así lo afirma la prolija Sentencia en un, sin embargo, breve pasaje de su Fto. Jur. 15, sin duda el más trascendental de toda ella:

"Nada impide que el Estatuto de Autonomía [...] al atribuir las competencias que han de ejercer los poderes públicos autonómicos, les impongan de modo directo, criterios o directrices para su ejercicio o que lo hagan, de modo indirecto, mediante la formalización de enunciados o declaraciones de derechos a favor de los particulares. Se trata, en ambos casos, de mandatos al legislador y restantes poderes públicos autonómicos, imponiéndoles prescripciones que son vinculantes para los mismos con independencia de la veste de que se revistan...

Por tanto, en el ámbito de lo dispuesto por el artículo 147.2.d) CE los Estatutos de Autonomía no pueden establecer por sí mismos derechos subjetivos en sentido estricto, sino directrices, objetivos o mandatos a los poderes públicos autonómicos. Por ello, cualquiera que sea la literalidad con la que se expresen en los Estatutos tales prescripciones estatutarias, han de entenderse, en puridad, como mandatos a los poderes públicos autonómicos, que aunque les vinculen sólo pueden tener la eficacia señalada”.

En primer lugar resulta chocante que la Sentencia proclame repetidamente su aperturismo a la inserción en los Estatutos de declaraciones de principios, derechos, etc. cuando de manera paralela ella misma desautoriza la inclusión precisamente del grueso de los derechos subjetivos de los ciudadanos. Así, a partir de este peculiar planteamiento muchas de las argumentaciones siguientes de la Sentencia pierden peso e incluso se tornan huecas.

Por otra parte, es igualmente llamativa la confusión en que incurre en cuanto a los conceptos "criterios o directrices", por una parte, y "enunciados o declaraciones de derechos" por otra; y asimismo es oscuro el concepto "mandatos al legislador". En el primer párrafo afirma que las dos primeras categorías son "mandatos al legislador", es decir, figuras equivalentes. Sin embargo, el segundo párrafo habla de "directrices, objetivos o mandatos" con lo cual parece hablar de figuras distintas; por añadidura la deficiente redacción del último inciso deja la grave duda de si la frase "tales prescripciones estatutarias" (que han de considerarse como "mandatos a los poderes públicos autonómicos") se refiere a las "directrices y objetivos" o a "los derechos subjetivos en 
sentido estricto". En fin, no queda claro algo tan fundamental como si por "mandato al legislador" hay que entender cualquiera de esos contenidos o sólo los proclamados como derechos subjetivos, lo cual plantea la gran duda de si la Sentencia utiliza el "mandato al legislador" en un sentido lato y "blando" equivalente a la figura del principio rector o si lo emplea en su acepción "dura", o sea, como orden imperativa dirigida precisamente al legislador para que este materialice lo exactamente previsto por la lex superior.

En segundo lugar, ocioso es decir que la Sentencia no toma partido por ninguna de las dos tesis que enfrentan a la doctrina, o sea, la admisibilidad o no de que los Estatutos proclamen derechos, pues lo que hace es tomar una tercera vía que en verdad no satisface ni a los detractores de los derechos estatutarios (ya que el ideario de la Sentencia se opone a esa tesitura) ni menos aún a los partidarios de la presencia en los Estatutos de derechos subjetivos auténticos, pues la Sentencia, a pesar de su aparente alineación con esta postura doctrinal, supone a la postre un fiasco para ella. Es evidente que el esfuerzo que este sector de la doctrina ha desplegado en defensa de la inclusión de las tablas de derechos en los Estatutos no tenía por objeto ese grupúsculo de derechos de corte institucional, $-e x$ art. 147.2.c- las más de las veces incluso preterido por esa doctrina.

Volviendo a la solución postulada por la Sentencia pueden distinguirse en ella las dos posiciones siguientes:

a) En el ámbito del artículo 147.2.d) CE, los Estatutos no pueden establecer por sí mismos derechos subjetivos en sentido estricto, sino directrices, objetivos o mandatos ${ }^{158}$. La Sentencia no motiva, como era necesario, un pronunciamiento de tal calado, aunque los motivos de ello no pasen desapercibidos. Es significativo que tras dicha declaración la Sentencia añada a renglón seguido que "De este modo [sic] las referidas prescripciones de los Estatutos [o sea, los derechos] no quebrantan el artículo 139.1 CE", lo que equivale a decir que de otro modo sí podrían quebrantarlo; o dicho de otra forma, que para salvar la

158 Así, una vez detectado por la Sentencia que el artículo 17.1 del Estatuto de la Comunidad Valenciana es un derecho nuevo derivado de las competencias autonómicas sobre aguas y no la repetición de un derecho fundamental de la Constitución, queda privado de la triple condición que a los derechos constitucionales reconoce el artículo 53.1 CE, y de la nota de la aplicabilidad directa; de tal forma que dicho precepto estatutario "aunque formalizado en su dicción como derecho se sitúa en la órbita de las directrices, objetivos básicos o mandatos dirigidos a los poderes públicos valencianos". Fto. Jur. 18. 
posible inconstitucionalidad del precepto estatutario que consagra un derecho (por atentar contra el principio de igualdad) es necesario convertir tal $d e-$ recho, en un principio rector o mandato al legislador, es decir, en una norma desactivada, no capaz de colisionar con el ordenamiento en vigor ni, por tanto, de invadir con rango estatutario posibles competencias estatales. En esta línea se sitúa el expresivo voto particular de uno de los magistrados disidentes ${ }^{159}$.

b) El derecho subjetivo nace cuando se completa su régimen jurídico y es por ello justiciable. Así lo sostiene la Sentencia: los derechos enunciados por el Estatuto "necesitarán para adquirir plena eficacia del ejercicio por el legislador autonómico de la competencia normativa que le es propia, de manera que el principio o derecho enunciado carecerá de justiciabilidad directa hasta que se concrete, efectivamente, su régimen jurídico, pues sólo entonces se configurarán los consiguientes derechos subjetivos de los ciudadanos". (Fto. Jur. 15). En fin, por si quedara alguna duda, el mismo Fto. Jur. queda cerrado con un pasaje de igual corte aseverativo, que resume la posición de la mayoría de la Sala:

"En conclusión, los Estatutos de Autonomía, que en el ámbito institucional del contenido estatutario pueden establecer derechos subjetivos por sí mismos, en el ámbito de atribución competencial requieren de la colaboración del legislador autonómico, de tal manera que las prescripciones estatutarias relativas a este último ámbito, cualquiera que sea el modo literal en que se enuncien han de entenderse, según antes se acaba de decir, como mandatos, orientaciones u objetivos, dirigidos a los poderes públicos autonómicos para el ejercicio de competencias que el Estatuto atribuya”.

${ }^{159}$ En efecto, el magistrado Sr. MARTÍN DE HIJAS califica esa transformación de las declaraciones de derechos en meros objetivos, directrices u orientaciones como un "ardid dialéctico" (aptdo. 3 del voto particular) para salvar la constitucionalidad del precepto, lo que considera rechazable. Afirma -aptdo. 4- que "el juicio de constitucionalidad de una declaración de derechos en los Estatutos de Autonomía no puede solventarse con independencia de la veste de que se revistan pues serán la estructura normativa del precepto estatutario y el concepto en que se inserta el factor jurídicamente relevante para decidir si una declaración de derechos en un Estatuto de Autonomía supone en sí el establecimiento de los derechos de que se trate [...] Me resulta un puro artificio dialéctico -añade el magistrado- prescindir de la estructura normativa del precepto si con ello se le hace decir lo que no dice [...] Si el texto estatutario es tal que no puede negarse que en él se esté estableciendo un derecho, aunque su justiciabilidad pueda ser quizás imprecisa, no puede negarse apriorísticamente que pueda existir [...]. Me resulta intelectualmente inaceptable el dar por sentado que el legislador ha dicho otra cosa distinta...”. En el mismo sentido hay que registrar la crítica de FERNÁNDEZ FARRERES, G., a quien esta conversión de los derechos en principios le parece "manifiestamente injustificada y por tanto arbitraria". ¿Hacia una nueva doctrina constitucional..., cit., pág. 120. 
De estas declaraciones, tan breves como trascendentes, se infieren las siguientes tres conclusiones:

- Primera, la Sentencia viene a elevar a dogma la afirmación de que es imprescindible la interpositio legislatoris para la creación de un derecho, no obstante lo cual excluye de esta inexorable regla los derechos estatutarios relacionados con las instituciones autonómicas ex art. 147.2 c) CE. Ni que decir tiene que tal aseveración es discutible en grado sumo.

- La segunda conclusión, derivada de la anterior, es que para la Sala el nacimiento de un derecho subjetivo sólo se produce cuando el legislador ordinario haya completado o concretado su régimen jurídico ("pues sólo entonces se configurarán los consiguientes derechos subjetivos de los ciudadanos"). O sea, según la tesis de la Sentencia, para la configuración de un derecho es imprescindible la intermediación de la legislación ordinaria (pues el Estatuto no se basta por si solo para hacerlo) y que esa legislación -habrá que entender incluidas, lógicamente, tanto leyes como disposiciones reglamentarias- haya dado término al proceso de definición que conlleva todo derecho. Se trata, a nuestro juicio, de una afirmación rotunda en extremo que resuelve de plano una cuestión compleja en la que hay que barajar no pocas precisiones e incluso tesis absolutamente contrarias, tal como la defendida en el sustancioso voto particular de uno de los magistrados discrepantes ${ }^{160}$.

- Conectado a lo anterior, el tercer posicionamiento de la Sentencia versa sobre otra cuestión sumamente delicada y controvertida que la Sentencia resuelve por la vía más rápida, sin reflexión alguna: el verdadero derecho sólo es tal si es justiciable ${ }^{161}$; y sólo es accionable ante los órganos judiciales, co-

\footnotetext{
${ }^{160}$ En efecto, se opone radicalmente a lo que postula la Sentencia el parecer del magistrado don Vicente CONDE MARTÍN DE HIJAS, quien afirma que: "el derecho de que se trate se tiene por su consagración genérica en la norma estatutaria, sin que su existencia dependa ya de la ulterior norma de desarrollo, y ello independientemente de la eventual indefinición del contenido y de las dificultades que puedan derivarse de esa indefinición en el momento de su justiciabilidad. El derecho existe por su consagración legal”. Lo contrario -abunda el voto particular- supondría convertir en condición de existencia del derecho la regulación infraordenada, cuando es la regulación infraordenada la que debe estar condicionada por la proclamación del derecho. Critica la Sentencia sobre este punto, GARRORENA MORALES, A., La constitucionalidad de los nuevos Estatutos..., cit. pág. 77.

${ }^{161}$ En el voto particular del magistrado Sr. CONDE MARTÍN DE HIJAS, el razonamiento es muy distinto: "No cabe invertir los términos del problema, anteponiendo el elemento de la justi-
} 
mo queda dicho, cuando el legislador concreta su régimen jurídico. La Sentencia cierra así el círculo, encadenando rígidamente las tres conclusiones expresadas en una ecuación trimembre: derecho público subjetivo = complitud de su regulación $=$ accionabilidad ante los Tribunales .

Es lógico preguntarse sobre cuáles hayan sido los objetivos pretendidos con esta solución tan extraña como inmotivada. Aunque la STC 247/2007 no los explicite, es evidente que con la degradación de los derechos que la Sentencia postula se producen los efectos siguientes: a) queda desactivada la eficacia directa de los preceptos lo que facilita el propósito de no declararlos inconstitucionales; b) se evita la confrontación de la Ley orgánica aprobatoria del Estatuto con las propias competencias del Estado; c) queda enervado el argumento de las posibles desigualdades interterritoriales (art. 139.1. CE) y la creación de privilegios (art. 138.2 CE) y con ello la acusación al Estado de generar estas diferencias; d) queda desactivado en gran medida el argumento de la petrificación que producen los derechos cuando se insertan en los Estatutos; e) especialmente, priva de valor directo a todo enunciado referido a derechos fundamentales -salvo las meras repeticiones- eliminando así todo riesgo de dar respaldo a algún precepto indebido en este campo.

Ahora bien, la consecución de tales objetivos comporta un elevado coste que no cabe silenciar: ante todo, se doblega la voluntad de la Ley, al hacerle decir lo que ésta no ha querido decir, ni dice. Pero además hay que resaltar la producción de otros "daños colaterales": a) quedan privados de eficacia directa derechos perfectos que no necesitarían de norma complementaria alguna; b) se tornan inexigibles directamente innumerables derechos sociales que no suponen coste económico alguno; c) multitud de sujetos privados quedan liberados de sus obligaciones para con titulares de derechos sociales precisamente sustentados por terceros y no por la Administración.

Volveremos sobre los pronunciamientos de la Sentencia 247/2007 más adelante, al tratar del valor de los derechos sustantivos proclamados en los Estatutos.

ciabilidad del derecho para admitir, o negar, la existencia de éste. La realidad es la contraria: $\mathrm{Si}$ el derecho existe (y eso le corresponde decirlo al legislador y no a este Tribunal, es justiciable, cualquiera que pueda ser el problematismo de esa justiciabilidad". 


\section{LA EFICACIA DE LOS ENUNCIADOS ESTATUTARIOS}

Evidentemente hay que estar y pasar por lo que ha resuelto la STC 247/2007 de 12 de diciembre, y concretamente por lo que declara sobre el valor jurídico de los derechos que los Estatutos proclaman. Su tesis es clara al respecto y, por tanto, es causa finita. Pero, sentado esto, no queda cegado el camino a la reflexión y la crítica, lo que resulta propiciado por la Sentencia al no haber motivado con un mínimo esmero la razón de una tesis tan drástica como la de afirmar que sólo son verdaderos derechos subjetivos los enunciados estatutarios que reproducen derechos fundamentales y los derechos relacionados con las "instituciones autonómicas propias" (art. 147.2.d) CE. Por ello, vale la pena replantear tales extremos; lo que hacemos seguidamente.

\section{Los enunciados estatutarios puramente retóricos}

En los Estatutos originarios, carentes de las tablas de derechos y principios que ofrecen los recientemente aprobados o en curso, no faltan declaraciones, pronunciamientos o proclamas de diverso tipo y alcance, difíciles de catalogar e incluso de calificar como normas jurídicas en algunos casos ${ }^{162}$. Todo ese material ha venido siendo tratado de un modo uniforme, englobado en una suerte de categoría común, la de las "normas programáticas", sobre la que ha caído el peso de todos los prejuicios y recelos acumulados en torno a la validez jurídica de estas normas, siendo patente la influencia que en esto ha tenido el tratamiento dado en Italia a este tipo de proclamaciones ${ }^{163}$.

162 Un inventario de ellos en SÁNCHEZ FÉRRIZ, R., "Derechos y libertades...", en Revista Valenciana d'Estudis Autonòmics, cit. El ejemplo más significativo y comentado por la doctrina es el del artículo 12 del Estatuto de Autonomía de Andalucía de 1981, que contenía una larga lista de "objetivos básicos" con evidente vocación de "principios rectores", ello dentro del Título Preliminar "Disposiciones Generales".

${ }^{163}$ Es muy ilustrativo el relato de la lucha de CALAMANDREI, desde su alta responsabilidad en la Asamblea constituyente, contra las falsas normas que sólo expresan "promesas consoladoras, programas y deseos", "leyes ficticias -como las del legislador fascista- trucadas, meramente figurativas, con las que se ingeniaba para presentar como verdadero lo que en realidad todos sabían que no lo era ni podría serlo", PACE, A., "Derechos de libertad y derechos sociales en el pensamiento de Piero Calamandrei” en Revista de Estudios Políticos”, núm. 63, 1989, pág. 54 y ss. BIGLINO CAMPOS ha resaltado la jurisprudencia de la Corte Costituzionale negando naturaleza jurídica a las disposiciones estatutarias referidas a los derechos de las personas y a los principios rectores, a los que sólo reconoce una función de naturaleza cultural e incluso política. "Los espejismos..." en Derechos, deberes..., cit., pág. 55. 
Ese tratamiento de las "normas programáticas", a veces incluso despectivo, no es riguroso por su simplismo, por unificar artificiosamente una realidad diversa y sobre todo porque la propia Constitución española y muy señaladamente los nuevos Estatutos de Autonomía obligan a discriminar y, por tanto, a no amalgamar cosas de naturaleza diferente.

En efecto, el legislador estatutario, en ese su afán de imitar a la Constitución, traslada a los Estatutos el esquema de la parte dogmática de aquélla, de lo cual resulta que sus contenidos se encuentran organizados, bien como derechos subjetivos, bien como principios rectores. Estas dos categorías absorben prácticamente el componente sustantivo de los nuevos Estatutos, amén de las lógicas declaraciones que se contienen en los preámbulos o títulos preliminares que suelen expresar los grandes valores y aspiraciones de la Comunidad de que se trate. Se quiere decir que prácticamente no queda margen para esas proclamas o declaraciones políticas a las que sí cabe negar a priori verdadero carácter jurídico. En suma, hay que distinguir entre el ámbito de las meras declaraciones de buenas intenciones o promesas indefinidas y el de las declaraciones propiamente jurídicas, como son las formuladas bajo la veste del derecho subjetivo o de un principio rector. Distinto es que algunos de estos últimos, por su deficiente configuración, puedan resultar poco operativos o incluso devenir ineficaces; pero éste es otro problema.

La doctrina se ha planteado, desde el prejuicio de la ajuricidad de las "normas programáticas", si es o no oportuno que figuren en los Estatutos, aunque sean jurídicamente inútiles. En su favor se arguye su valor pedagógico, su papel como elemento de concienciación y estímulo de la solidaridad ${ }^{164}$; en su contra, el peligro que conllevan de crear falsas expectativas y el consiguiente descrédito de las leyes ${ }^{165}$. En nuestra opinión, para que esa polémica siga teniendo sentido hay que descontar de ella los principios rectores y, por supuesto, los derechos subjetivos, dejándola circunscrita a las puras proclama-

164 Vid. consideraciones detalladas sobre el particular en SÁNCHEZ FÉRRIZ, R., "Derechos y libertades públicas..." en Revista Valenciana d'Estudis Autonòmics, cit., págs. 97 y ss. Asimismo, APARICIO WILHEMI, M. y PISARELLO, G., "El reconocimiento de derechos..." cit., pág. 10; BIGLINO CAMPOS, P., "Los espejismos..." en Derechos, deberes y principios..., pág. 55.

165 PACE, A., "Derechos de libertad..." en Revista de Estudios Políticos, cit., pág. 59; BIGLINO CAMPOS, P., "Los espejismos..." en Derechos, deberes y principios...", cit., pág. 55. PISARELLO, G., "Los derechos sociales en el constitucionalismo democrático" en Boletín Mexicano de Derecho Comparado, núm. 92. 
ciones políticas, a las fórmulas "declamatorias" y demás textos no clasificables en las conocidas categorías formales; y sobre este conjunto, ya atípico y residual, parece correcto decir, que tales pronunciamientos añadidos sobran y que más que aclarar y aleccionar enturbian el esquema y perturban el entendimiento del valor de las Cartas de principios y derechos sociales ${ }^{166}$.

\section{El valor de los principios rectores estatutarios}

Especial relieve ha recobrado el clásico tema de los principios rectores de la política social y económica, habida cuenta su importante presencia en los nuevos Estatutos de Autonomía. Basta decir que son unos doscientos en total los enunciados formulados como principios rectores que se recogen en los últimos Estatutos aprobados o en tramitación. En suma, un tema viejo vertido en odres nuevos.

Para la materia social, estos principios rectores tienen tal relevancia que la doctrina suele usar la sinonimia derechos sociales = principios rectores. Precisamente, esta especie de simbiosis conceptual ha conferido a los llamados derechos sociales una imagen débil, la misma que transmite el Cap. III en su comparación con el Cap. II del Título I de la Constitución. Pero esto, que es básicamente cierto, requiere algunas precisiones: a) no todos los derechos sociales de la Constitución están contenidos en el Capítulo III, sino que se encuentran diseminados en diferentes apartados de su

${ }^{166}$ El vigente Estatuto de Andalucía de 2007 dedica su Título I -30 artículos- al enunciado de "Derechos sociales, deberes y políticas públicas". Sin embargo, el estatuyente ha repetido la fórmula del Estatuto de 1981 dedicando, dentro del Título Preliminar, un extensísimo artículo 10 que relaciona los "objetivos básicos de la Comunidad Autónoma" produciendo así una masiva reiteración de contenidos y lo que es peor, la generación de dudas en las partes no coincidentes; en suma, una inflación de carga dogmática no necesaria de la que acaso puedan derivarse más inconvenientes que ventajas. Lo que quizás fue oportuno en 1981 ya no lo ha sido en 2007.

${ }^{167} \mathrm{Al}$ respecto, valga citar el derecho de huelga y el derecho a la educación (dentro de la sección $1^{\text {a }}$ del Cap. II) los derechos relacionados con el trabajo ex art. 35 (dentro de la sección $2^{\mathrm{a}}$ del Cap. II). Obvio es decir que estos derechos sociales sí son verdaderos derechos y no meras garantías institucionales. Vid. PECES-BARBA MARTÍNEZ, G., Curso de Derechos fundamentales: Teoría General, Universidad Carlos III, BOE, Madrid, 1999, págs. 444 y ss.; PÉREZ LUÑO, A., Los Derechos Fundamentales, $5^{\text {a }}$ edic., Tecnos, Madrid, 1993, págs.187 y ss.; VICENTE GIMÉNEZ, T., La exigibilidad de los derechos..., cit., págs. 24 y ss.; COLMENERO GUERRA, J. A., "Algunas notas sobre la tutela jurisdiccional de los derechos sociales" en Nuevas políticas públicas: Anuario multidisciplinar para la modernización de las Administraciones Públicas, núm. 2, 2006, págs. 288 y ss. 
texto ${ }^{167}$; b) no todo lo que contiene el Cap. III es materia social, pues también comprende algunas garantías institucionales sobre otras materias ( p. ej.., art. 52, organizaciones profesionales); c) los llamados "derechos sociales" del Cap. III son tan sólo -en el puro plano constitucional- principios rectores, no "derechos", aunque esto sea discutido por la doctrina en relación con algunos de ellos, señaladamente el medio ambiente, el derecho de los menores a ser asistidos por sus padres o el derecho a una vivienda digna y adecuada ${ }^{168}$.

Huelga decir que estos principios rectores no tienen la fuerza que es propia de los clásicos derechos constitucionales civiles y políticos, mas ello no permite subestimar su valor jurídico, debiendo por el contrario afirmarse del modo más resuelto que se trata de genuinas normas jurídicas -“mandatos de op-

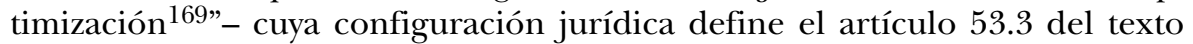

168 Por lo que se refiere al presunto "derecho" al medio ambiente dimanante del artículo 45 CE, la literatura es muy copiosa. Véase por todos JORDANO FRAGA, J., La protección del derecho a un medio ambiente adecuado, J.M. Bosch editor, Barcelona 1995, pág. 455 y ss; y más recientemente, del propio autor, "Medio Ambiente y el nuevo Estatuto de Autonomía de Andalucía. Una visión preliminar" en Revista Andaluza de Administración Pública, núm. 65, 2007, págs. 42-43. VELASCO CABALLERO, F., "El medio ambiente en la Constitución: ¿Derecho público subjetivo y/o principio rector?" en Administración de Andalucía, Revista Andaluza de Administración Pública, núm. 19, 1994. También está abordado el tema en LÓPEZ MENUDO, F., "El derecho a la protección del medio ambiente" Revista del Centro de Estudios Constitucionales, núm. 10, Madrid, 1989, págs. 161 a 191 y en "Planteamiento constitucional del medio ambiente. Distribución de competencias Estado-Comunidades Autónomas" en Protección administrativa del medio ambiente, Cuadernos de Derecho Judicial, CEPJ, Madrid, 1995, págs. 9 y ss. En cuanto al derecho a la salud, es importante al respecto -aunque anterior a la Constitución- el libro de ESCRIBANO COLLADO, P., El Derecho a la salud, cit. págs. 37 y ss. Vid. GARCÍA MACHO, R., Las aporias de los derechos fundamentales sociales y el derecho a una vivienda, IEAL, Madrid, 1982, págs. 136 y ss.; COSSÍO DÍAZ, J. R., Estado social y derechos de prestación, cit., págs. 252 y ss.

169 GARCÍA DE ENTERRÍA, E., "La Constitución como norma" en La Constitución española. Estudio sistemático dirigido por los profesores A. Predieri y E. García Enterría, Civitas, $2^{\mathrm{a}}$ edic, Madrid, 1981. RUBIO LLORENTE, F., "La Constitución como fuente del Derecho" en VV. AA.: La Constitución española y las Fuentes del Derecho, IEF, Madrid, 1979. Vid. asimismo PRIETO SANCHÍS, L., "Los derechos sociales y el principio de igualdad...", cit., págs. 38 a 42; CARRILLO LÓPEZ, M., "La eficacia de los derechos sociales...”, cit., pág. 70; GARCÍA MORALES, A. F., La justiciabilidad de los derechos económicos, sociales y culturales, cit., págs. 127 a 130. Vid. asimismo COBREROS MENDAZONA, E., sobre el tratamiento de estas "normas programáticas" en la doctrina italiana, en "Reflexión general sobre la eficacia normativa de los principios constitucionales rectores de la política social y económica del Estado" en RVAP 19, 1987, págs. 27 y ss. 
constitucional ${ }^{170}$. Todo lo anterior se desprende de la Constitución de modo claro así como que tales principios van dirigidos a todos los poderes públicos y, por ende, a los legisladores autonómicos. De lo expuesto va de suyo que son deberes y no simples facultades, lo cual significa que la Constitución compele a seguir la dirección marcada, a realizar la obra bosquejada por el Cap. III, Tít. I en conjugación con el artículo 53.3 y el fondo principial resultante de los artículos $1.1^{\circ}$ y $9.2 \mathrm{CE}^{171}$.

Cualquier legislador podría convertir en genuinos derechos subjetivos todos y cada uno de los "derechos sociales" que se citan en ese Cap. III - en la medida en que ello sea técnicamente posible- con lo cual habría logrado ejecutar óptimamente ese desiderátum constitucional. Ahora bien, la Constitución no exige que se llegue necesariamente a esa meta, que ni siquiera menciona en relación con algunas de las materias contenidas en dicho Capítulo (formación profesional, promoción de la ciencia y la investigación, participación de la juventud, protección de consumidores y usuarios, etc.). Dicho de otra forma, aunque potencialmente todos los principios rectores pueden llegar a convertirse en derechos públicos subjetivos ello no es necesario para dar cumplimiento al postulado del Estado social ínsito en la Constitución. En el desarrollo de ese postulado existen otros hitos o grados, otras acciones capaces de sintonizar con la dirección querida por el texto constitucional ${ }^{172}$.

${ }^{170}$ Es obligado recordar que, a diferencia de los derechos fundamentales, los principios rectores no son de aplicación inmediata, ni están sujetos a reserva de ley y sólo podrán ser alegados ante la Jurisdicción ordinaria de acuerdo con lo que dispongan las leyes que los desarrollen; pero la legislación positiva, la práctica judicial y la actuación de los poderes públicos han de estar informados del reconocimiento, el respeto y la protección de estos principios. No pueden dar lugar a ningún recurso de amparo, ni a ningún recurso ordinario, pero sí a la declaración de inconstitucionalidad de una ley.

${ }^{171}$ Así, FERNÁNDEZ RODRÍGUEZ, T. R., "Los derechos fundamentales y la acción de los poderes públicos" en Revista de Derecho Político, núm. 15, 1982, pág. 32; BIGLINO CAMPOS, P., "Los espejismos...", cit., pág. 47.

172 Distinto parecer sostiene FERNÁNDEZ RODRÍGUEZ, T. R., al afirmar que la Ley debe regular los principios rectores constitucionales "de modo que queden completos, con todos los elementos y todos los atributos propios de un derecho subjetivo perfecto e inmediatamente exigible [...] la Constitución no puede satisfacerse con cualquier Ley en este punto concreto [...]. La libertad de configuración del Legislador está aquí en el quantum (y por extensión en el quomodo), nunca en el an, ni en el quando, ni en el quid". "Las garantías de los derechos sociales" en Las estructuras del bienestar en Europa, cit., págs. 464 y ss. Creemos que tal planteamiento sólo es sostenible respecto de algún sector en concreto y especialmente tutelado por la Constitución, tal como 
En cuanto al alcance regulador del régimen de esos principios del Cap. III hay que hacer la distinción siguiente. En tanto la acción social de que se trate no haya alcanzado el punto de cristalización que representa su configuración como derecho subjetivo, regirán las reglas que la Constitución refiere a los principios rectores: informan la legislación positiva, la práctica judicial y la actuación de los poderes públicos; pero si la ejecución del principio rector llega eventualmente a su punto óptimo, es decir, a su consagración como derecho subjetivo, es evidente que su régimen será el que es propio de los derechos según el ordenamiento jurídico general (especiales garantías para su revocación, indemnizabilidad, accionabilidad ante los Tribunales...), lógicamente con las modulaciones que resulten de su normativa reguladora específica. Esta última observación es importante teniendo en cuenta que muchos de los principios rectores enunciados en el Cap. III, Tít. I de la CE han venido siendo convertidos en derechos por los legisladores autonómicos y han sido recogidos como tales en los Estatutos de autonomía de la última hornada. Ocioso es decir que en estos casos, bien numerosos, las notas jurídicas que en abstracto se predican de los principios rectores quedan superadas o eclipsadas por esa vinculación más fuerte que supone la sujeción al régimen de los derechos subjetivos, abstracción hecha de si éstos se encuentran diseñados de una forma más o menos perfecta.

Por tanto, es posible hablar de un itinerario cuyo punto de partida radica en la nuda letra del Cap. III, Tít. I de la Constitución y su término en el hecho mismo de la creación de derechos subjetivos. En los puntos intermedios de ese trayecto hay un universo de acciones posibles: despliegue de medios personales, de recursos económicos y materiales, adopción de medidas jurídicas, imposición de deberes a terceros, creación de organizaciones, establecimiento de instalaciones, centros, etc. Los poderes públicos vienen obligados a insertarse en ese itinerario, aunque la Constitución no fije, por lo que se refiere al legislador, el dónde de esa incorporación ni el cuándo. Ciertamente, la Constitución no predetermina qué han de hacer los poderes públicos ni cuánto han de hacer para que pueda considerarse que cumplen esos principios, lo que obliga a reconocer que el legislador cuenta con un amplio margen de discrecionalidad - salvo que se trate de mandatos constitucionales concretos- para

la Seguridad Social, precisamente resaltado por el citado profesor, pero que no es generalizable a cualquier otro principio rector como un imperativo, (entre otras cosas porque no todos los principios rectores son susceptibles técnicamente de ser transformados en derechos subjetivos), ello salvo que no se trate en realidad de principios rectores o directrices sino de auténticos mandatos precisamente dirigidos al legislador para que haga algo en concreto. 
andar ese camino en función de las circunstancias políticas y económicas reinantes. Pero no es discrecional la decisión misma de seguir o no dicho diseño, y en esto se advierte la existencia de un cierto "contenido esencial ${ }^{173}$ " en los principios rectores, si bien se trate de un "núcleo" mucho más pequeño y menos "duro" que el de los derechos fundamentales propiamente dichos. Pero aun así no es desdeñable la fuerza que puede irradiar de ese "modesto" núcleo esencial del principio rector en orden a disciplinar problemas graves que pueden acaecer en un momento dado; así, su fuerza para reprimir la posible existencia de políticas contrarias a dichos postulados, la falta de implantación injustificada de medidas sociales elementales, la paralización o bloqueo caprichoso del proceso de mejora de las acciones y servicios y, desde luego, la eventual regresión de los niveles de atención social ya conseguidos sin justa causa que la explique y legitime. Todo esto que acaba de apuntarse plantea problemas dificultosos que exigen ser tratados meticulosamente. Pero de entrada debe quedar en primer plano la idea de que aunque el legislador está vinculado por los principios rectores goza de una discrecionalidad notable (aunque no absoluta) y por ello los jueces y tribunales han de actuar con especial prudencia para no incurrir en un "activismo judicial" improcedente en este ámbito ${ }^{174}$.

Expuesto lo anterior, la pregunta obligada es si los principios rectores que están enunciados precisamente en un Estatuto se encuentran, respecto de su Comunidad Autónoma concreta, en análoga posición a la que ocupa el Cap. III, Tít. I de la CE respecto de todos los poderes públicos del Estado. Pues bien, la respuesta exige distinguir entre los principios insertos en el Estatuto que sean pura reproducción de los constitucionales de dicho Cap. III y los principios de nuevo cuño surgidos del poder dispositivo del estatuyente autonómico.

En relación con los primeros, al tratarse de principios rectores constitucionales simplemente reproducidos, podría decirse que su fuerza de obligar

${ }^{173}$ Sobre estos extremos vid. PRIETO SANCHÍS, L., "Los derechos sociales y el principio de igualdad sustancial" en Revista del Centro de Estudios Constitucionales, núm. 22, año 1995, pág. 50. Con especial énfasis en la interdicción de que los jueces puedan sustituir las omisiones del legislador o de la Administración en esta materia, RUIZ-RICO RUIZ, G., "Derechos sociales y Reforma de los Estatutos de Autonomía. El derecho a la vivienda en Nuevas políticas públicas. Anuario...,cit., pág. 82. SASTRE ARIZA, S., "Hacia una teoría exigente...", cit. pág. 266.

174 Vid. en este sentido CARRILLO LÓPEZ, M., "La eficacia de los derechos sociales: entre Constitución y Ley" en Jueces para la democracia, núm. 36, 1999, pág. 68; SASTRE ARIZA, S., "Hacia una teoría exigente..." cit., págs. 268-269. 
deriva de la Constitución misma y no del Estatuto. No obstante, hay que advertir que el mandato ínsito en el principio rector constitucional, flexible de suyo, se rigidiza al plasmarse en el Estatuto pues ya el legislador autonómico quedará más intensamente vinculado. Se quiere decir que la estatutorización de un principio rector constitucional añade, al menos de facto, un superior efecto congelador. Y más reticencias aún levantaría el supuesto, absolutamente frecuente, de que los principios rectores constitucionales sean calificados como derechos subjetivos no por la ley ordinaria sino por el Estatuto, que así añadiría a tales principios rectores una carga de rigidez de la que carecen en la propia Constitución y que presuntamente ésta habría querido descartar. Sin embargo, no parece que estas distorsiones sean patológicas, ya que, en definitiva, siguen en lo sustancial la línea querida por la Constitución, esto es, el impulso y la tutela para la materia social que ella misma -no cualquier otra instancia ni Ley- propugna.

Mayor problema presentan las materias distintas de las anteriores -sociales o no- que el Estatuto configura como principios rectores, si se parte del prejuicio de que los Estatutos no pueden congelar más de lo que les permite el artículo 147.2. CE. (desde una interpretación estricta de éste), ni siquiera en el nivel -moderado- de intensidad que es propio de los principios rectores ${ }^{175}$.

Pero este argumento de la rigidez, dotado o no de razón, hay que desecharlo tras la aparición de la STC 247/2007, a resultas de la cual son precisamente los principios rectores los que condensan todo el contenido dogmático de los Estatutos, dado que los derechos que éstos enuncian no son, según la Sentencia, verdaderos derechos, sino otra cosa. Esta degradación universal de los derechos públicos subjetivos a la condición de principios rectores o de mandatos -la sentencia no afina sobre esta distinción, como ya hemos advertido-, realza el protagonismo de estos últimos, que pasan así a ostentar un papel ya no secundario, sino central, dentro de los Estatutos.

\footnotetext{
175 Tal es la postura que sostiene DÍEZ-PICAZO, como más arriba quedó reseñado. Vid. nota 105. La misma opinión sostiene MUÑOZ MACHADO, al decir que las normas programáticas estatutarias no tienen el mismo valor que las normas programáticas de la Constitución, no son vinculantes, porque "la congelación de opciones políticas y organizativas sólo se produce en el texto constitucional, pero no es función propia del legislador ordinario que, en definitiva, es quien aprueba el Estatuto", concluyendo que "no tiene cobertura constitucional esta pretensión de vincular al legislador regional futuro" (MUÑOZ MACHADO, S., Derecho Público...I, $2^{\mathrm{a}}$ edic., cit., pág. 382. No obstante, debe contrastarse lo dicho con la opinión del propio autor que ya quedó expuesta en la nota núm.116
} 
Por tanto, los principios rectores estatutarios, todos ellos, tienen no sólo valor de normas jurídicas -quedan definitivamente relegadas las opiniones que los tachaban de pura retórica- sino que vinculan al legislador autonómico. Es evidente que una vez negada por la STC 247/2007 fuerza vinculante $i n$ mediata a los derechos estatutarios, haber negado también la fuerza vinculante mediata de los principios rectores hubiera supuesto el colapso, una especie de callejón sin salida para esas nutridas tablas de enunciados dogmáticos que figuran en los Estatutos de esta nueva época. Esta fuerza vinculante de los principios la reconoce expresamente la Sala a través de un pasaje que ya quedó citado más arriba ${ }^{176}$, y no hace la Sentencia ninguna consideración acerca de la petrificación que pueden producir estos principios rectores sobre las opciones políticas futuras; pero esto no ha de extrañar si se tiene en cuenta que la Sentencia, respecto a los derechos -cuyo efecto petrificador es obviamente superior-, no maneja este argumento ${ }^{177}$. En efecto, degrada los derechos de naturaleza sustantiva a la categoría de principios rectores no porque congelen el debate político sino porque aquéllos, según la Sentencia, no nacen en verdad por obra de los Estatutos sino en virtud de las leyes que los desarrollen.

Por consiguiente, la STC 247/2007 viene a respaldar la idea de que los principios rectores estatutarios se encuentran frente a la Comunidad Autónoma respectiva en similar posición que los principios rectores constitucionales frente a todos los poderes públicos. Si esto es así habrán quedado trasplantadas al plano autonómico las mismas cuestiones que históricamente han planteado las relaciones entre las normas programáticas -configuradas como principios rectores por la CE- y la actividad pública para el desarrollo de éstos, problemas que se resumen en los eventos siguientes: a) el legislador ordinario dicta leyes que no concuerdan con el sentido de algún principio rector; b) el legislador no impulsa lo mandado por los principios rectores; c) se dictan medidas regresivas respecto de los niveles de bienestar ya alcanzados. En torno a

176 "Nada impide que el Estatuto de Autonomía en cuanto norma institucional básica de la Comunidad Autónoma, al atribuir las competencias que han de ejercer los poderes públicos autonómicos, les impongan, de modo directo, criterios o directrices para su ejercicio o que lo hagan, de modo indirecto, mediante la formalización de enunciados o declaraciones de derechos a favor de los particulares. Se trata, en ambos casos, de mandatos al legislador y restantes poderes públicos autonómicos, imponiéndoles prescripciones que son vinculantes para los mismos con independencia de la veste de que se revistan" (Fto. Jur. 14).

177 Ello salvo la alusión, casi de pasada, que la STC 247/2007 hace en su Fto. Jur. 6, in fine, a la que más abajo haremos mención. 
estos problemas se ha ido formando una dogmática que arranca de la época de Weimar. Debemos determinar si esa dogmática es referible a las tablas contenidas en los nuevos Estatutos, lo que haremos una vez expuestas las reflexiones del siguiente epígrafe.

\section{El valor de los derechos sustantivos proclamados en los estatutos de auto- nomía}

Es necesario tener muy presente las conclusiones de la STC 247/2007 que quedaron expuestas supra. Valga recordar aquí su punto fuerte: los pretendidos derechos subjetivos estatutarios no son realmente derechos, pues éstos nacen sólo cuando queda completado su régimen jurídico y son por ello justiciables; y esto es hacedero solamente por las normas que desarrollan los Estatutos, no por estos mismos.

La primera reserva que esta tesis suscita es que con ella queda eludida la voluntad del legislador estatuyente, convirtiendo lo que ha querido decir en otra cosa; grave operación, censurada en el voto particular de uno de los magistrados discrepantes ${ }^{178}$. Con toda razón, éste viene a decir que si el derecho existe o no es algo que "le corresponde decirlo al legislador y no a este Tribunal". Es evidente que el TC dicta en este caso una Sentencia de las denominadas "manipulativas" -PIZZORUSSO ${ }^{179}$ - mediante la cual desustancializa los derechos convirtiéndolos en principios rectores o mandatos al legislador; por tanto, no inmediatamente aplicables. Ya vimos cómo uno de los magistrados disidentes califica esta transformación como "un ardid dialéctico para salvar la constitucionalidad del precepto". Y es que en verdad, la operación no deja de ser una variante de esa disociación entre validez y eficacia que la propia Sentencia formula en su Fto. Jur. 6, siguiendo la cual, como ha observado GARRORENA, podrían mantenerse en un Estatuto normas inválidas por inconstitucionales siempre que no desplieguen eficacia, doctrina que dicho autor lle-

${ }^{178}$ Ver nota 159.

179 "Las Sentencias manipulativas del Tribunal Constitucional italiano" en El Tribunal Constitucional, vol. I, Instituto de Estudios Fiscales, Madrid, 1981, págs. 279 y ss. Queremos aquí referirnos al tipo de sentencias que, siguiendo a ZAGREBELSKY, define DÍAZ REVORIO, F. J., como aquellas que "proceden a la transformación del significado de la Ley, más que a su eliminación o su interpretación conforme a la Constitución”, Las Sentencias interpretativas del Tribunal Constitucional, Lex Nova, Valladolid, 2001, pág. 134. 
ga a calificar de extravagante ${ }^{180}$. Pero el aspecto que importa resaltar ahora es el hecho mismo de la sustitución de la voluntad del legislador estatuyente operada por la Sentencia, suplantación ésta en la que también incurre la doctrina científica cuando en aplicación de algún apriorismo más o menos razonado, sostiene que los derechos que enuncian los Estatutos no son tales derechos, transformando así fácticamente lo que el legislador ha querido formular y ha formulado como un derecho, lo haya sido con mayor o menor acierto técnico $^{181}$.

Estos planteamientos permiten apreciar cómo subyace en los derechos sociales ese su sino fatal de tender hacia la claudicación, algo que posiblemente no ocurriría o al menos no con esa facilidad si se tratara de derechos de otra naturaleza. En suma, aquellos parecen arrastrar el peso muerto de una tradición que ha venido afirmando su condición de mandatos dirigidos al legislador, insusceptibles por naturaleza de ser reclamados judicialmente ${ }^{182}$. Cree-

${ }^{180}$ La constitucionalidad de los nuevos Estatutos...cit. págs. 87 y ss.

181 Un ejemplo de esta tendencia puede verse en BIGLINO CAMPOS, P., quien no duda en calificar como "espejismo" el Título I del Estatuto de Cataluña, aduciendo que "no contiene lo que el constitucionalismo contemporáneo entiende como una declaración de derechos"..."no estamos -dice- ante un texto completo y sistemático que defina en su totalidad el estatus de los ciudadanos ante el poder público y en la sociedad". Además añade la autora que "en la mayoría de las ocasiones, ni tan siquiera estamos ante facultades que, en términos estrictos, puedan calificarse de derechos subjetivos. Los que se recogen son, casi siempre principios cuya eficacia jurídica depende de la legislación posterior...", "Los espejismos....", cit. págs. 49-50. A la vista del Estatuto no es fácil compartir la opinión de la profesora BIGLINO pues la afirmación más rotunda que cabe hacer sobre su Título I es que en éste -al igual que en otros Estatutos recientes- es absolutamente nítida la distinción entre derechos y principios rectores. Por otra parte, afirmar que los enunciados que proclaman derechos no son tales por el hecho de que remitan a otras normas la fijación de determinados requisitos, no es algo que pueda resolverse del modo apodíctico reseñado. MARTÍN REBOLLO, L., también parece mantener una opinión crítica frente a estos derechos estatutarios pero en un tono moderado: "Son, quizá, derechos, aunque su operatividad real dependerá de las leyes que los desarrollen, más allá de los cuales juegan el papel inspirador de los principios en sí mismos loables", "Sobre los Estatutos de Autonomía y sus pretendidas reformas: algunos recordatorios y otras reflexiones" en La Reforma de los Estatutos de Autonomía, Junta de Castilla y León, cit. pág. 62. Como se ve, no llega a decir MARTÍN REBOLLO que el derecho nazca con las leyes de desarrollo, ni que el derecho estatutario sea en verdad un principio rector, que es lo que vino a afirmar luego la STC 247/2007, tesis ésta que no suscribimos.

182 Vid. DE LA QUADRA-SALCEDO JANINI, T., y la doctrina alemana que cita al respecto, "El régimen jurídico de los derechos sociales estatutarios. Reflexiones tras la STC 247/2007 de 12 de diciembre" en Revista General de Derecho Constitucional, 5, 2008, pág. 5. 
mos que hay que desterrar este apriorismo, sin duda comprensible desde el punto de vista histórico pero injustificable en términos jurídicos. No hay derechos de peor condición que otros por naturaleza; menos aún, si cabe, si los derechos en cuestión cuadran con lo querido por la Constitución, como ocurre con los derechos de corte social. Por ello, a la vista de los enunciados estatutarios (sean derechos o principios rectores), no puede marginarse en absoluto la voluntas legis; y hay que decir que esta voluntad es clarísima en la inmensa mayoría por no decir la totalidad de los derechos proclamados como tales en los Estatutos de la reforma reciente.

Por tanto, si la ley - en este caso el Estatuto- formula un enunciado como derecho subjetivo procederá analizar su estructura, su suficiencia o no para desplegar eficacia por sí mismo, determinar qué elementos puedan faltarle, en su caso, para que sea posible su puesta en práctica (fijación de requisitos subjetivos u objetivos, determinación de cuantías, definición de la competencia o regulación del procedimiento, etc.); en fin, valorar todo lo que constituye el contexto de cualquier derecho. En el Derecho público, el derecho subjetivo se construye con frecuencia, como bien se sabe, por un grupo normativo no encerrado en una sola disposición y creado todo a un tiempo, sino fragmentado y disperso en la trama del ordenamiento, hecho a retazos y en momentos temporales distintos ${ }^{183}$. Por tanto, no estamos ante una situación rara ni novedosa. En el peor de los casos, tras esa valoración pudiera llegarse a la conclusión de que un derecho estatutario concreto adolece de ineficacia a radice, por no ser posible delimitar o aprehender su objeto mismo en términos jurídicamente operativos o porque el propio sistema jurídico carezca de resortes para dar respuesta eficaz a un eventual ataque al derecho de que se trate. Ciertamente, hay que admitir que pueda existir algún derecho rayano en la utopía y que se intuya como irrealizable incluso poniendo a su servicio las vías judiciales existentes. Pero esto no permite descalificar globalmente la categoría del derecho público estatutario de carácter social.

En suma, no es correcto convertir por vía interpretativa el derecho subjetivo en un principio rector o en mandato al legislador, es decir, en algo que

\footnotetext{
${ }^{183}$ Vid. VILLAR PALASÍ, J. L., Curso de Derecho Administrativo, Tomo I, Introducción, Teoría de las normas y grupos normativos, Universidad Complutense, Madrid, 1972, pág. 161 y ss. Asimismo, muy expresivamente, MEILÁN GIL, J. L., "La distinción entre norma y acto administrativo", RAP, 1967, pág. 45 y ss.

184 Obvio es decir que esa opción de la Ley ha de ser respetada. Como señala CALAMANDREI el legislador tiene la opción de consagrar derechos subjetivos del individuo o utilizar fórmulas menos comprometedoras en las cuales se hable de poderes o de deberes genéricos del Estado, que
} 
ha sido descartado conscientemente por la propia ley ${ }^{184}$. Siendo esto así hay que aceptar que la consagración de un derecho público subjetivo es un acto por el cual el legislador formula un compromiso sito en un nivel cualitativamente superior al que corresponde a un principio rector, directriz o mandato, pretendiendo con ello que el individuo adquiera desde ya una situación jurídica defendible judicialmente, y no simplemente que la acción legislativa se encamine en la dirección tuitiva de las necesidades sociales. La diferencia entre ambas opciones es notoria lo que obliga a rechazar toda operación transformadora de la opción querida por el legislador en la no deseada por éste. Es más, incluso en el supuesto de derechos subjetivos que por su mala configuración carecieran de toda operatividad como tales, sería rechazable la atribución de las cualidades inherentes a los principios rectores, a pretexto de dotarlos de alguna efectividad, sencillamente porque no es ésta la vocación con la que fueron alumbrados por la ley; serían, pues, derechos subjetivos fallidos o inoperantes, no principios rectores o recomendaciones ${ }^{185}$. En suma, parece que el punto de partida más correcto es estar en primer término a lo que la ley diga. Si esta ley proclama un derecho de carácter social, será un derecho público subjetivo, a secas, como cualquier otro. Debe descartarse el prejuicio de que, por ser sociales, estos derechos tengan algún estigma congénito que los haga especialmente vulnerables, aunque no cabe ignorar cómo pesa aquí la tradición en el sentido de considerarlos como derechos estructuralmente diferentes, señaladamente porque son costosos y además vagos e indeterminados ${ }^{186}$.

El estigma aludido tiene mucho que ver con la máxima de FORSTHOFF: "ningún término es más ambiguo ni más susceptible de abusos que el término social" ${ }^{187}$. Las causas de esta debilidad pueden resumirse en dos, aunque exis-

pueden tener relevancia respecto a la colectividad, pero sobre las cuales no puedan fundarse pretensiones individuales jurídicamente tuteladas. Cit. por PACE, A., "Derechos de libertad y derechos sociales..." cit., pág. 56. Del mismo modo, GIANNINI, M. S., en relación con las prestaciones públicas admite que las normas pueden configurar las situaciones subjetivas de los particulares bien como intereses legítimos o bien como derechos subjetivos. Diritto Admministrativo, I, Giuffrè, Milano, 1970, pág. 526.

${ }^{185}$ Ello, sin perjuicio del valor interpretativo que pudieran seguir teniendo, para esclarecer cualquier situación; valor que le vendría no por ser un principio rector, sino porque esto es lo propio de cualquier norma relevante del ordenamiento jurídico, como son las que establecen derechos.

${ }^{186}$ Sobre estos extremos, vid. la exposición de PISARELLO, G. en Los derechos sociales y sus garantías, cit. págs. 59 y ss.

${ }^{187}$ ABENDROTH, W.; FORSTHOFF, E.; DOHERING, K., El Estado social, CEC, Madrid, 1986, pág. 65 . 
tan más ${ }^{188}$ : la razón económica, factor ciertamente poderoso que desde siempre ha teñido de precariedad el campo de la acción social; y la dicción misma de los preceptos que contienen estas declaraciones, en los que se ha querido ver más la retórica que la estructura de las verdaderas normas. Estas dos "razones" han sido demoledoras para la imagen y firmeza de la acción social. Consideremos seguidamente la parte jurídica de la cuestión.

Una influencia muy negativa acerca de la "seriedad" de las formulaciones de derechos sociales -aparte de la tradición de la doctrina italiana ya mencionada- ha tenido la opinión de FORSTHOFF al marcar diferencias entre los derechos de libertad (que admitirían las formulaciones legales abstractas y generales) y las garantías jurídicas sociales que carecen de un contenido constante. Los derechos sociales, dice FORSTHOFF, "no se pueden captar en una norma abstracta, susceptible de aplicación ${ }^{189}$ ". Pero ya el propio autor deja constancia de la polémica habida en torno al artículo 131 de la Constitución de Weimar en el que se reconoce a éste el carácter de norma inmediatamente aplica$b l e$, no obstante la reserva que el mismo artículo hace en previsión de una ulterior regulación por ley ${ }^{190}$.

No se puede dar por buena la tesis según la cual la imposibilidad de la aplicación inmediata de los derechos sociales venga dada por su propia inde-

\footnotetext{
188 ABRAMOVICH, V. y COURTIS, Ch. señalan las siguientes: a) problemas de determinación de la conducta debida por parte de los poderes públicos; b) la autorrestricción del Poder Judicial frente a cuestiones políticas y técnicas; c) la ausencia de mecanismos procesales adecuados para la tutela de estos derechos; d) la escasa tradición del control judicial en la materia. Los derechos sociales como derechos exigibles, cit., pág. 93.
}

${ }^{189}$ ABENDROTH, W.; FORSTHOFF; E.y DOHERING, K., "Concepto y esencia del Estado...", cit., pág. 88. El autor se refiere también a la impotencia en general de la Constitución puesto que no es tarea suya la regulación de las distintas materias "ni puede serlo puesto que debe imponerse una brevedad lapidaria. Por esta razón no siempre consigue el grado de concreción suficiente que haga posible la inmediata aplicación de sus normas".

190 Ibídem y nota 17. El propio FORSTHOFF reconoce que la evolución del Estado Social de Derecho "conduce a que las 'garantías' sociales no queden relegadas en la región vaporosa de una promesa meramente programática de la que tomaría nota el legislador que es el primer obligado, sino a reconocerle una vinculación jurídica directa”, ídem, pág. 89. Por su parte NIETO GARCÍA, A. hace referencia a la discusión de la literatura alemana "como resultado de la constatación de que algunos artículos de la Constitución de Weimar tenían un carácter inequívocamente programático y, por tanto, no eran directamente aplicables, "Peculiaridades jurídicas de la norma constitucional”, RAP 100-102, 1983, pág. 377. 
terminación, ya que la estructura lingüística de estas declaraciones no es muy diferente de la de otras normas constitucionales. Además, como advierte PRIETO SANCHÍS, no es cierto que todos los derechos prestacionales aparezcan con la misma estructura gramatical ${ }^{191}$. Ciertamente, como afirmara en su día el profesor GARRIDO FALLA, para que una declaración tenga carácter jurídico y no sea mera retórica debe tener "estructura lógica de norma jurídica: que sea una orden, mandato, prohibición"192; es decir, no es válida cualquier fórmula. Pero esto debe ser común a cualquier proposición jurídica, de modo que no cabe, a nuestro juicio, añadir más exigencias por tratarse de derechos sociales, aun sin dejar de reconocer que los derechos de abstención precisen por lo general de menos exigencias que los derechos de prestación para su perfecta configuración y plena exigibilidad.

Los derechos en general, si vienen formulados en un texto constitucional, un Estatuto, una Carta o cualquier otra Declaración solemne, es lógico que presenten la concisión y el estilo que son propios de estos instrumentos, sin que por ello queden abocados a su desnaturalización como tales derechos ${ }^{193}$. Tratándose de leyes ordinarias que establecen derechos, sí cabe exigir una mayor concreción de los elementos que conforman el derecho subjetivo porque en el seno de una ley es hacedera la regulación cumplida de todos los requisitos que han de concurrir, o al menos de sus piezas fundamentales. Pero llevar esta misma exigencia al plano de las normas superiores va contra la realidad y la naturaleza de las cosas. Es obligado aceptar esta realidad, pues de no ser así la alternativa no sería otra que la de afirmar que ninguna norma superior podría crear derechos y que sólo pueden hacerlo las secundarias, lo cual es una conclusión quimérica. Esta reflexión hace que sea difícil compartir la tesis central de la STC 247/2007.

${ }^{191}$ PRIETO SANCHÍS, L., "Los derechos sociales y el principio de igualdad...”, cit., pág. 39. La afirmación del texto es de CASCAJO CASTRO, J. L., La tutela constitucional de los derechos sociales, CEC, Madrid, 1988, pág. 70. Asimismo, COSSÍO DÍAZ, J. R., Estado social y derechos de prestación, cit.

192 GARRIDO FALLA, F. "Comentario al artículo 53" en Comentarios a la Constitución, Civitas, Madrid, 1980, pág. 50.

${ }^{193}$ Lo afirmado en el texto puede ser compatible, a nuestro juicio, con el reconocimiento de que en muchos de estos casos estemos ante "proposiciones jurídicas incompletas", en los términos de LARENZ K., (traídas a colación por Alejandro NIETO, "Peculiaridades jurídicas...", cit. pág. 389) porque esa incomplitud no merma el valor jurídico de la norma ni, a nuestro parecer, enerva necesariamente la validez inmediata de lo que la norma declara. 
Refiriéndose al plano de la ley ordinaria TORNOS MAS señala los requisitos que deben ser regulados para la conformación de un derecho subjetivo, precisamente en materia social. Como quiera que éste consiste en la atribución a su titular de una acción frente al sujeto obligado a su prestación, ello requiere determinar: a) qué sujetos son los titulares del derecho; b) qué sujetos son los obligados a realizar la prestación; c) qué condiciones se requieren para que se reconozca el derecho; d) a qué prestaciones en concreto se tiene derecho; e) mecanismos eficaces para hacer efectivo el contenido del derecho ${ }^{194}$.

Es lógico que este atinado cuadro de requisitos pueda ser cubierto enteramente por una ley determinada, pero no sería sensato pretender que todo este cúmulo de precisiones tuviera que venir contemplado en una norma estatutaria como condición necesaria para tener el derecho por establecido. Además, hay que observar que, pese al aparente laconismo de las formulaciones constitucionales o estatutarias, éstas suelen cubrir el contenido esencial; y hay que tener en cuenta que en dichas declaraciones existen elementos implícitos por cuanto pertenecen al ordenamiento jurídico general, de tal forma que estos elementos constituyen contenido natural del derecho proclamado de que se trate ${ }^{195}$. Por lo general quedará por determinar qué condiciones se re-

194 "Efectividad de los derechos y exigibilidad de los servicios sociales" en Documentación Administrativa, 271-272, 2005, págs. 380 y ss. MUÑOZ MACHADO señala las circunstancias que difuminan o afianzan el hecho de la exigibilidad de lo establecido por una ley y apunta como dato negativo el abuso de la técnica de remitirse a leyes y decretos posteriores, "La crisis del Estado del bienestar y la cuestión de la reversibilidad de los derechos sociales: el caso de los minusválidos", en La integración social de los minusválidos: balance después de diez años de vigencia de la Ley, (dir. Muñoz Machado), 1993, pág. 20; observación sin duda acertada en el plano de la legislación ordinaria.

195 Así, la determinación de los sujetos titulares del derecho viene establecida por la norma estatutaria ("Todos tienen derecho", "Los valencianos tienen derecho", "se reconoce el derecho de los minusválidos...", etc.); asimismo, la norma describe la prestación de que se trata con mayor o menor precisión, según la naturaleza de la cosa; y puede considerarse como contenido implícito o natural la determinación del sujeto obligado (dentro del aparato administrativo será el órgano competente) e incluso el procedimiento a seguir (el que esté establecido ad hoc o el cauce procedimental común). Estos elementos implícitos juegan un papel análogo al que Herman HELLER atribuye a los "elementos constitucionales no normados y por aquellos otros normados pero no jurídicos" para completar los preceptos constitucionales del contexto principial que les rodea, Teoría del Estado, Fondo de Cultura Económica, México, $7^{\mathrm{a}}$ reimp. 1974, pág. 274; reed. por Edit. Comares, Granada, 2004, pág. 292. Muy expresivamente Alejandro NIETO resalta este dato de la incomplitud constitucional "cuyos preceptos actúan como perchas en las que hay que encajar luego el contenido material propiamente dicho y que les viene de fuera", "Peculiaridades jurídicas...", cit. pág. 390; idea sin duda brillante y certera, pero no generalizable a cualquier precepto que establezca derechos e incluso principios, pues tanto unos como otros pueden alcanzar a decir perfectamente lo que quieren. 
quieran para el reconocimiento del derecho, si es que se requieren algunas; $y$ esto, por la propia lógica del sistema normativo, será objeto de remisión a la ley. Por tanto, a este requisito hay que entender principalmente referida la cláusula de estilo "en los términos que establezca la ley", u otra semejante, que a veces acompaña a la formulación de un derecho estatutario.

El examen de los Estatutos permite extraer conclusiones muy sólidas sobre esta importante cuestión. En términos generales puede decirse que aunque se den en algún caso imperfecciones técnicas en la configuración de los derechos, en la gran mayoría de los supuestos no dejan dudas de que efectivamente establecen derechos subjetivos operativos ab initio; y siendo esto así, es claro que esta realidad choca frontalmente con la tesis central de la STC 247/2007 según la cual todo derecho subjetivo proclamado en un Estatuto sólo puede ser un derecho en virtud de las normas que los desarrollen, sentando así el axioma de que todos los enunciados estatutarios necesitan desarrollo, lo cual es imposible de compartir. La Sentencia tendría que haber dicho que muchos de esos enunciados, o la mayoría si se quiere, necesitan desarrollo, pero no todos sin excepción, planteamiento éste que ni siquiera tiene el respaldo de una justificación técnica puesto que la Sentencia en cuestión excluye de esta regla absoluta los derechos subjetivos de corte institucional ex art. 147.2.c) y, por supuesto, quedan excluidos los derechos fundamentales del Cap. II en el sentido de que, aunque precisen de la interpositio legislatoris, ello no les priva de aplicabilidad directa, todo lo cual hace aún más inasumible la tesis de la Sentencia.

Ésta introduce otros apriorismos, tal como que el derecho sólo surge cuando es exigible judicialmente; de este modo, abraza -conscientemente o no- la tesis kelseniana y excluye del concepto de derecho social otros atributos y facultades distintas de la accionabilidad ante los Tribunales que un gran sector de la doctrina ha venido tradicionalmente defendiendo con el fin de apuntalar al máximo posible la débil figura del "derecho social" tal como ha sido vista históricamente ${ }^{196}$. Es claro que la opción de la Sentencia por el binomio "exigencia ante los órganos judiciales = regulación ultimada del derecho" sirve bien al propósito de enervar el valor y la eficacia inmediata de los derechos proclamados en los Estatutos, postergándolos en el tiempo y en el rango, pero se trata en realidad de un artificio.

\footnotetext{
196 Sobre la necesidad de defender las "garantías primarias" de los derechos sociales -distintas de las garantías jurisdiccionales- es muy expresiva la exposición de SASTRE ARIZA, S., "Hacia una teoría exigente...", cit. pág. 264 y ss.
} 
Creemos que el planteamiento debe ser el inverso. Cuando una norma estatutaria define un determinado beneficio precisamente como un derecho esto es lo primero que debe lucir -su exigibilidad ante los Tribunales-y por tanto condicionar la ulterior tarea normativa y administrativa que en su caso deba concurrir. A partir de esta premisa pueden darse dos situaciones básicas: a) que la norma estatutaria, por sí misma, logre configurar el derecho con tal perfección o complitud que éste sea ya ejercible directamente por estar claramente definida la posición del sujeto y porque su pretensión queda introducida, ope legis, en su patrimonio jurídico; b) que sea imposible alcanzar ese grado de perfección solamente por obra de las normas -sea la originaria del Estatuto que proclama el derecho o los que se dicten para su desarrollo y complemento- de tal modo que sea preciso añadir a la actividad normativa una actividad administrativa de comprobación que en puridad será la que defina la posición del sujeto y, por tanto, la existencia misma y la extensión de su derecho. Éste será el supuesto más frecuente, lo que permite concluir que sólo en muy contados casos las normas de desarrollo son las que ponen fin al proceso de definición del derecho subjetivo, a diferencia de lo que sostiene de modo general la STC 247/2007.

En suma, además de los derechos que son ejercitables directamente desde la norma que los consagra, -que no son pocos- se produce en los restantes casos un proceso de definición del derecho subjetivo que puede ser más o menos complejo. La tesis que entendemos correcta es la exigibilidad como punto de partida, que podrá ser gradualmente más amplia y efectiva cuanto más ultimado se encuentre el proceso de definición del derecho subjetivo en cuestión ${ }^{197}$. Esta exigibilidad como principio abre por tanto la garantía no sólo en los supuestos de derechos que se encuentren perfectamente definidos sino, como lúcidamente ha expuesto DE LA QUADRA-SALCEDO JANINI, en otras situaciones no perfectas, tales como aquellas en que el órgano judicial sólo pudiera garantizar el derecho con un contenido mínimo ${ }^{198}$, o cuando por ser im-

\footnotetext{
${ }^{197}$ A semejanza -como oportunamente recuerda DE LA QUADRA- de lo que ocurre con los derechos fundamentales que requieren una interpositio legislatoris para ser plenamente eficaces, que no obsta a su exigibilidad directa siquiera en su contenido mínimo (STC. 15/1982 de 23 abril; 254/1993 de 20 julio y 31/1994 de 31 enero). "El régimen jurídico de los derechos sociales...", cit. pág. 20.

198 Ante el incumplimiento del legislador de su deber de hacer eficaz el derecho subjetivo proclamado por el Estatuto, la alternativa en este caso, dada la ausencia de regulación, no puede ser otra que la responsabilidad del legislador por omisión. Se trataría -como dice el propio autor- de trasplantar las razones aducidas por el TJCE en el asunto Francovich y ratificadas luego en Brasserie du Pêcheur y otras muchas, ídem, pág. 26.
} 
posible la exigencia de la prestación ni siquiera con un contenido mínimo, sí podría exigirse en su lugar una reparación económica ${ }^{199}$. Con toda razón señala PISARELLO que la justiciabilidad de un derecho no es una cuestión de todo o nada. Es más bien un concepto graduable que varía según la circunstancia, admitiendo distintos tipos de intervenciones judiciales ${ }^{200}$.

En fin, entendemos que cuando una norma primaria proclama un derecho todo ha de ponerse en acción con urgencia para optimizar la operatividad de lo que ya ha sido creado. De no razonar así se llegaría a la chocante paradoja de que nunca podrían crear derechos subjetivos las normas principales, quedando deferida esta alta función a las normas secundarias, a las últimas órdenes ministeriales y disposiciones semejantes que son las que acaban perfilando la traza de todo derecho. En suma, la voluntad de la ley, pura y espontánea, quedaría al momento desplazada y sustituida por el decisionismo de la maquinaria gubernamental y administrativa, por sus programaciones, sus ritmos, sus criterios de oportunidad y conveniencia, etc.

Dicho lo anterior, examinemos la realidad que ofrecen los Estatutos. Como éstos no dejan de tener un lado oscuro que no cabe minimizar, vaya éste por delante. Así, algunos enunciados, aunque formulados como derechos, son prácticamente imposibles como tales derechos ya que su estructura resulta impropia para ello; en suma, se trata de falsos derechos o del uso impropio del término ${ }^{201}$. Existen otros enunciados que más que conferir un poder frente a un obligado, como es lo propio del derecho subjetivo, hacen referencia al "de-

${ }^{199}$ En análogo sentido cabe citar el parecer de GOMES CANOTILHO, J. J., quien habla de un "derecho originario" que después encuentra dificultades para convertirse en derecho operativo, postura que no comparte COSSÍO DÍAZ quien, desde el prejuicio de que todo derecho enunciado en norma superior exige desarrollo, opina que la expresión "derecho" no genera un derecho sino la obligación de los poderes públicos de instrumentar los medios necesarios para darle cumplimiento, postura ésta que no compartimos. Vid. Estado Social y Derechos de prestación, cit., pág. 242.

${ }^{200}$ Los derechos sociales y sus garantías, cit. pág. 89.

${ }^{201}$ Así, cuando el Estatuto de Andalucía proclama como derechos que "los planes educativos incorporarán los valores de la igualdad, diversidad cultural, multilingüismo" o "se complementará el sistema educativo con enseñanzas específicas propias de Andalucía”; o cuando el artículo 16 del Estatuto balear clasifica como "Derechos sociales" los que no son sino principios rectores en materia social: "protección y defensa de la creatividad, promoción de la participación de la sociedad civil en los asuntos públicos”. 
recho-aspiración", tan típico en este ámbito social ${ }^{202}$. También pueden citarse no pocos ejemplos de derechos con un objeto tan vago que no son susceptibles de constituir un verdadero derecho ${ }^{203}$. En otros casos, dicho enunciado resulta vano, o confuso, o utópico ${ }^{204}$.

Pero estas imperfecciones, nada extrañas en un contexto tan dispar y tan proclive a cuidar más el "mensaje" que la técnica formal, no pueden empañar la realidad que ofrecen los Estatutos. La gran mayoría de sus preceptos que enuncian derechos están formulados de forma solemne e inequívoca, casi ritual, como ya señalamos supra. Pero, además, ha de resaltarse que gran parte de esos derechos, por no decir la mayoría, para ser aplicados directamente no precisan de la intermediación de norma alguna, o a lo sumo de una mínima colaboración normativa sin entidad para entender deferido el derecho proclamado a ese requisito complementario. Ciertamente, no cabría negar la aplicabilidad directa y la posibilidad de exigir ante los Tribunales la represión de conductas o actos administrativos que atentasen a derechos tales como "vivir libre de malos tratos", "acceder a los servicios públicos de salud", "libertad de elección de médico y centro", "presentar iniciativas legislativas", "realizar el testamento vital", "formular solicitudes y recursos", "ser informado sobre el estado de salud", "a recibir gratuitamente libros de texto", "derecho a una segunda opinión médica”, "al uso de las lenguas oficiales"; y una lista intermi-

\footnotetext{
${ }^{202}$ Así, por ejemplo, el derecho "a gozar de una vida y un medio ambiente seguro" (art. 17 Estatuto Comunidad valenciana).

${ }^{203}$ P. ej. "gozar de servicios públicos de calidad", (Est. Comunidad Valenciana); "velar por la conservación y mejora de los recursos hidrológicos", "evitar transferencias de aguas", "acceso a la cultura”, (Est. Aragón). Efectivamente, son difícilmente articulables como derechos, bien porque son mandatos operables sólo por los poderes públicos o porque recaen sobre un objeto difuso, no susceptible de ser soporte de una pretensión dirigida a los Tribunales.

${ }^{204}$ P. ej. "queda garantizado el derecho de acceso de los valencianos a las nuevas tecnologías..." (art. 19.2 Est. Comunidad Valenciana) ¿Quién garantiza? ¿cómo queda garantizado?, cabe preguntarse. Entre los utópicos, p. ej., "derecho de los consumidores a la educación y formación suficiente en la materia", "derecho a una acción voluntaria de calidad". Como ejemplo de enunciados confusos, el contenido en el Estatuto balear: "Todas las personas tienen derecho a que los poderes públicos promuevan su integración cultural" (art. 18.2), una especie de sincretismo entre derecho y principio rector que el Estatuto de Andalucía también utiliza en su artículo 25: "Para favorecer el ejercicio del derecho constitucional a una vivienda digna y adecuada, los poderes públicos están obligados a la promoción pública de la vivienda", del que claramente se deduce que ese "derecho" no es judicialmente exigible.
} 
nable de enunciados análogos ${ }^{205}$ que permiten concluir que existen derechos no necesitados de una prolija descripción para que puedan ser efectivos, bien por sí solos o bien con el apoyo del ordenamiento establecido, operando éste como telón de fondo.

Son muy numerosos los supuestos en que junto a la formulación del derecho, el precepto estatutario remite a la ley con la fórmula de rigor ("con los requisitos que señalan las leyes", "en los términos que las leyes determinen..." y fórmulas análogas). Son muy abundantes en el Estatuto catalán y también, aunque en menor número, en el andaluz. Por su parte, el de Castilla-La Mancha sigue método distinto: formula una cláusula general ${ }^{206}$, no ad casum, como los anteriores. Pero cualquiera que sea el método hay que estar a la particularidad que presente cada precepto, pues ni dicha cláusula general supone que todos los derechos estatutarios necesiten del complemento o desarrollo de una ley, ni todos los que carecen de esa previsión podrían ser aplicados sin más.

En todo caso importa destacar que esas remisiones a la ley responden a una necesidad real y concreta, dada la imposibilidad de que el precepto estatutario descienda a pormenorizar requisitos exigibles, a establecer cuantías o demás elementos necesarios para la definición y operatividad plena del derecho ya constituido. Pero no puede decirse que tales remisiones obedezcan a la voluntad del Estatuto de abandonar a favor de la ley la creación del derecho ${ }^{207}$ y ni siquiera la libertad para desarrollarlo cuando el legislador lo crea oportu-

\footnotetext{
${ }^{205}$ Por ejemplo, el ramo de salud ofrece numerosos ejemplos de derechos de esta clase: a conocer la identidad del médico, a obtener la Carta de derechos y deberes que rigen los centros sanitarios, a una información inteligible, a estar acompañado de familiares en el momento de la muerte, etc., etc.,

206 Art. 6. "Los derechos de las personas reconocidos en el presente título se disfrutarán en los términos y condiciones de las normas que los desarrollen..."

${ }^{207}$ No se trata por tanto de una situación de "quiescencia" de la norma principal, es decir, de espera o dependencia respecto de la secundaria, fenómeno con frecuencia deliberado, como atinadamente señala NIETO GARCÍA, A., "Peculiaridades jurídicas..." cit. pág. 393. ORTEGA ÁLVAREZ, L., comparte esta postura al decir que a pesar de las remisiones que los Estatutos hacen a la ley para el ejercicio de los derechos, no estamos ante una situación similar a las declaraciones de principios u objetivos de los poderes públicos, "Los derechos ciudadanos en los nuevos Estatutos...”, cit. pág. 79.
} 
no, como es propio de los principios rectores ${ }^{208}$. En suma, esas remisiones estatutarias a la ley hacen difícil sostener -aunque la STC 247/2007 lo sostieneque la exigibilidad solamente surja cuando las normas de desarrollo establezcan esos complementos. Por el contrario, la tesis a defender es que los órganos productores de normas jurídicas se encuentran compelidos por el Estatuto a colaborar de manera inmediata para hacer plenamente eficaz el derecho ya establecido, so pena de incurrir en responsabilidad, salvo que el propio Estatuto disponga otra cosa para un período transitorio ${ }^{209}$.

La propia letra de algunos Estatutos avala esta línea interpretativa, contraria desde luego a la sostenida por la STC 247/2007. Así, desde la premisa de partida de que los derechos reconocidos en el Estatuto "vinculan a todos los poderes públicos" 210 y que los actos de los poderes públicos de la Comunidad que vulneren los derechos reconocidos en el Estatuto podrán ser objeto de recurso ante la jurisdicción correspondiente ${ }^{211}$, es patente la distinción que se hace entre la existencia del derecho y la posibilidad de su ejercicio, trasunto de la distinción bien conocida entre validez y eficacia de los actos jurídicos ${ }^{212}$.

\section{La vinculación entre las tablas estatutarias de principios y derechos y la le- gislación de desarrollo}

Desde Weimar, toda la teorética acuñada sobre la vinculación entre las proclamaciones de derechos sociales y la normativa de desarrollo se ha hecho ma-

\footnotetext{
${ }^{208}$ Es claro que no podemos compartir la opinión de FERRERES COMELLA según la cual cuando las normas estatutarias remiten a "las condiciones que la ley determine" son principios rectores aunque estén clasificadas como derechos”, "Derechos, deberes y principios...”, cit., pág. 33.

${ }^{209}$ Sólo el Estatuto de Cataluña (Dispos. Trans. Primera 1) contiene una previsión sobre este particular, según la cual se establece un período máximo de dos años para la emisión de leyes relativas al Título I.

${ }^{210}$ Artículo 37.1 del Estatuto catalán y artículo 38 del Estatuto andaluz.

${ }^{211}$ Artículo 39 del Estatuto Andaluz y artículo 21.4 del Estatuto de las Islas Baleares.

212 Así, el artículo 38 del Estatuto andaluz dispone que "El Parlamento aprobará las correspondientes leyes de desarrollo que respetarán, en todo caso, el contenido de los mismos [los derechos] establecido por el Estatuto, y determinarán las prestaciones y servicios vinculados, en su caso, al ejercicio de estos derechos"; y el artículo 22.4: "Con arreglo a la ley se establecerán los términos, condiciones y requisitos del ejercicio de los derechos previstos en los apartados anteriores". También el Estatuto de Aragón distingue entre los derechos y su ejercicio efectivo (art. 11.3) y lo mismo puede decirse del Estatuto de Castilla y León. (art. 17.1).
} 
nejando el concepto de "norma programática", esto es, una suerte de regla de valor jurídico incierto, hasta tiempos muy recientes. Sobre base tan inconsistente se explica que el argumento económico haya campado a sus anchas, prácticamente exento de sometimiento al Derecho y que baste la invocación a la palabra "crisis" para poner en movimiento la convicción fatal de que es lícito paralizar las acciones sociales en marcha e incluso echar abajo lo conseguido.

Es muy importante tener en cuenta que ese tratamiento fatalista ha tenido como referencia los "derechos sociales" como un todo conceptual, contrapuesto a los derechos de abstención, que serían, éstos sí, verdaderos derechos; contraposición simplista de viejo arraigo viciada con dos tópicos añadidos: a) que la efectividad de todos los derechos sociales depende de las circunstancias económicas; b) que todos ellos exigen de los poderes públicos acciones positivas. Esta visión uniformada de la heterogénea realidad ha llevado a la doctrina a hacer afirmaciones que son insostenibles por su carácter indiscriminado, al menos en la actualidad; así, la afirmación de que "los derechos sociales no son más que pretensiones legalmente reguladas" o que "el legislador determina lo que es un derecho social, pero él no está vinculado a los derechos sociales $^{213 "}$.

Pero nos encontramos ante ciertos hechos nuevos que obligan a replantear muy en serio las ideas que aún se siguen manteniendo sobre estas cuestiones: a) los principios rectores de la política social y económica son normas jurídicas que no admiten el liviano tratamiento dispensado tradicionalmente a las "normas programáticas", esa especie de cajón de sastre cuasi pintoresco; b) en las tablas de derechos sociales de los Estatutos aparecen ahora, junto a

213 GÓMEZ CANOTILHO, J. J., "Metodología 'fuzzy' y 'camaleones normativos' en la problemática actual de los derechos económicos, sociales y culturales" en Derechos y libertades. Revista del Instituto Bartolomé de las Casas, núm. 6, 1998, pág. 42. Así lo afirma el autor parafraseando a HAVERKATE. Asimismo asume la idea clásica que HABERLE suscribe: "Los derechos económicos, sociales y culturales se encuentran sometidos a las capacidades financieras del Estado" (pág. 44); y aún más, la inasumible afirmación de MARTENS, referida precisamente a los derechos públicos subjetivos, según la cual éstos sólo pueden ser garantizados "en el ámbito de lo posible" y de lo adecuado, y por este motivo se encuentran desprovistos de estatuto jurídico constitucional (pág. 44). El condicionante económico también adquiere un papel preponderante sobre el Derecho para VICENTE GIMÉNEZ, T., La exigibilidad de los derechos sociales, cit., pág. 98. BIGLINO CAMPOS, P. también sostiene la inviabilidad de ciertas demandas sociales contenidas en el Estatuto de Cataluña, "Los espejismos...", cit. pág. 41. En una posición más equilibrada, SASTRE ARIZA, S., "Hacia una teoría exigente de los derechos sociales", Revista de Estudios Políticos, 112, 2001, pág. 270. 
tales principios, no simples "derechos-aspiración" sino auténticos derechos subjetivos; c) las leyes ordinarias reconocen derechos en materia social sin que para ello tenga necesariamente que darse una conexión con principios proclamados en norma superior; basta con el ejercicio de la competencia.

Consecuentemente, resulta obligado abandonar el planteamiento tradicional de considerar la materia social -los llamados en sentido genérico u objetivo "derechos sociales"- como una categoría jurídica unitaria y por el contrario distinguir, muy claramente, entre principios y derechos dado que su respectivo tratamiento debe ser muy diferente.

En relación con los principios rectores estatutarios creemos que no existe obstáculo para admitir que ejercen frente a las leyes autonómicas el típico papel que juegan los principios rectores constitucionales. Así lo explicitan algunos Estatutos como quedó expuesto supra, y aunque en otros no figure específica aclaración al respecto no cabe duda de que la figura del principio rector forma ya parte de la cultura jurídica y está implícita en tales Estatutos. Por tanto, el dato de la subordinación jerárquica de las leyes autonómicas respecto de su Estatuto hay que relegarlo a un segundo plano ${ }^{214}$ y situar la cuestión en la clave flexible que es propia de los principios rectores en su relación con las normas y actos jurídicos que deben materializarlos. Ahora bien, esta dulcificación de la relación entre norma superior y subordinada, propiciada precisamente por razón de la discrecionalidad que es preciso otorgar al legislador en este ámbito, no ha de enervar la fuerza de ese pequeño "núcleo duro" ínsito en todo principio rector, que deberá así ejercer su papel compulsivo sobre la acción de las instancias autonómicas, siquiera sea en un nivel mínimo que al menos haga posible su supervivencia como mandato jurídico con alguna significación. Y ésta es la premisa mayor a partir de la cual han de resolverse los problemas inherentes a la relación entre los principios y la actividad normativa de desarrollo. Estos problemas, más arriba apuntados, pueden denominarse, en síntesis, como la desviación, la inactividad y el retroceso, problemas que vienen ya de lejos y que no parece que ofrezcan alguna especificidad o modulación relevante en este nuevo escenario constituido por los Estatutos y sus normas y actos jurídicos derivados. $\mathrm{Al}$ respecto cabe recordar lo siguiente:

- Por lo que se refiere a las normas que se desvien de lo querido por los principios rectores estatutarios hay que partir del reconocimiento al legislador

${ }^{214}$ Vid. in extenso sobre esta cuestiones AGUADO RENEDO, C., El Estatuto de Autonomía y su posición..., cit. págs. 535 y ss. 
de un amplio margen de interpretación del mandato. Por tanto, la confrontación que puede dar lugar a la declaración de que la norma es anti estatutaria ha de suponer una desviación cualificada, o sea, una colisión que no deje lugar a dudas. Pueden traerse a colación supuestos de esta clase resueltos por el TC que serían, mutatis mutandi, perfectamente extrapolables al ámbito autonómi$\mathrm{co}^{215}$. En efecto, no existe imposibilidad de principio alguna para impugnar ante el TC leyes autonómicas contrarias a lo establecido en los Estatutos, cualquiera que sea la materia, como ya quedó sentado supra, aunque no quepa ignorar las dificultades inherentes a la legitimación activa, más las añadidas que resulten de facto del hecho mismo de circunscribirse el conflicto a un ámbito autonómico.

- Mayores dificultades ofrece el control de la inactividad del legislador, cuando no impulse lo previsto en un mandato o principio rector (omisión total) o excluya del beneficio a grupos determinados de personas (omisión parcial). Este último supuesto es atajable por vía del principio de igualdad pero la omisión pura supone el vacío y ello acarrea los inconvenientes típicos de esta situación: la ausencia de norma impugnable y la dificultad de determinar el contenido concreto de lo que tendría que haberse desarrollado ${ }^{216}$. Como expusiera oportunamente PAREJO ALFONSO, el TC Federal alemán se ha mostrado rotundamente contrario a declarar la inconstitucionalidad de la inactividad del legislador ${ }^{217}$ y otros autores han destacado la dificultad existente en nuestro derecho para dar cauce a una pretensión de esta clase, pues la declaración en sí

215 Así, la STC 45/1989 que declaró inconstitucional la regulación legal del IRPF (Fto. Jur. 7) por contrario a la "protección social, económica y jurídica de la familia" (art. 39 CE); la STC 103/1983 de 22 de noviembre declaró la inconstitucionalidad de un precepto de la Ley General de Seguridad Social sobre la diferencia de tratamiento del régimen de viudedad según el sexo; también es de citar el caso del artículo 48 de la Ley de Arrendamientos Urbanos. Vid. GARRIDO GUTIÉRREZ, P., "El valor constitucional de los principios rectores. Comentarios a la STC 222/1992, de 11 de diciembre" en RVAP, 40, 1994.

216 GÓMEZ PUENTE, M., La inactividad del legislador: una realidad susceptible de control, Madrid, 1997, pág. 31. Un análisis reciente de la cuestión en DE LA QUADRA-SALCEDO JANINI, T., "E1 régimen jurídico de los derechos sociales estatutarios. Reflexiones tras la STC 247/2007, de 12 de diciembre" en Revista General de Derecho Constitucional, cit., págs. 9 y ss.

217 Estado social y Administración Pública. Los postulados constitucionales de la Reforma administrativa, Civitas, Madrid, 1983, pág. 55. En el mismo sentido, la jurisprudencia norteamericana descrita por ALONSO GARCÍA, R., en sus trabajos publicados en la REDC, núms. 2 (1982), 7 (1983) y 11 (1984). 
de estos incumplimientos constitucionales sí puede hacerla el Tribunal Constitucional $^{218}$; esto, a diferencia, como ha señalado COBREROS MENDAZONA, de lo que sucede con el artículo 283 de la Constitución portuguesa ${ }^{219}$, o lo que establece el ordenamiento comunitario frente a la inacción de las instituciones comunitarias mediante el recurso por inactividad previsto en el artículo 232 del TCE ${ }^{220}$. Expone COBREROS los esfuerzos de cierta doctrina -señaladamente MORTATI- en orden a vitalizar las posibilidades de control de esta inactividad legislativa y postula el propio autor, ante la atonía cierta deducible de la jurisprudencia constitucional ${ }^{221}$, la acertada propuesta de que "si la omisión del legislador ordinario es constitucionalmente relevante, el Tribunal Constitucional debe decirlo, ya que él no tiene más límite que la Constitución (y su propia Ley Orgánica)" 222 , a lo que cabe añadir que la regla extraíble de la Constitución, a la vista de los modos verbales que utiliza en los preceptos del Cap. III, Tít. I, es la de que el legislador debe actuar, y no la de que se abstenga, por lo que en principio existe un mandato constitucional que el TC tiene que tutelar sin perjuicio de que el poder público de que se trate pueda argüir de contrario sus legítimas razones -si las tiene- para mantener inédita o bloqueada una acción social propuesta por la Constitución.

${ }^{218}$ DE LA QUADRA-SALCEDO JANINI, T., “El régimen jurídico...”, cit. pág. 13.

${ }^{219}$ Sobre la solución portuguesa, vid. GONZÁLEZ MORENO, B., El Estado social, cit. pág. 215.

${ }^{220}$ COBREROS MENDAZONA, E., "Reflexión general sobre la eficacia normativa de los principios constitucionales rectores de la política social y económica del Estado" en RVAP, núm. 19, 1987, pág. 43. Asimismo, DE LA QUADRA-SALCEDO JANINI, T.: ídem. pág. 14. En general es imprescindible la obra de GUICHOT REINA, E., La responsabilidad extracontractual de los poderes públicos según el Derecho Comunitario, Tirant lo Blanch, Valencia, 2001. GÓMEZ PUENTE, M. señala que los resultados que se alcanzan en el Derecho comunitario son generalizables para cuantas situaciones de ablación o privación de derechos se produzcan a causa de una acción u omisión legislativa antijurídica, La inactividad del legislador, cit. pág. 35, 242 y ss. y 250. Vid. asimismo la importante obra de GALÁN VIOQUE, R., La responsabilidad del Estado Legislador, CEDECS, Barcelona, 2001, especialmente págs. 559 y ss.

${ }^{221}$ COBREROS cita la STC 24/1982 de 13 mayo, FJ 3, y la 74/1987 de 25 mayo, FJ 4. También la STC 45/1989 de 20 febrero había declarado un tanto abúlicamente que "es improbable que una norma legal cualquiera pueda ser considerada inconstitucional por omisión, esto es, por no atender, aisladamente considerada, el mandato a los poderes públicos y en especial al legislador, en el que cada uno de esos principios por lo general se concreta..." (FJ 4).

${ }^{222}$ COBREROS MENDAZONA, E.: ídem, pág. 47. En contra de esta posibilidad, COSSÍO DÍAZ, J. R., Estado social y derechos de prestación...cit. pág. 243. 
- El retroceso o recesión, aun siendo un fenómeno del mismo género que los anteriores es cualitativamente distinto puesto que no supone, como aquéllos, la frustración de expectativas sino la vuelta atrás, es decir, la rebaja o el despojo total de algo que se venía disfrutando, si bien no a título de derecho subjetivo. En suma un fenómeno de corte más bronco que se ha erigido, lógicamente, en el banco de pruebas de la efectividad de los principios rectores.

Como punto de partida es obligado referirse a la postura de K. HESSE, oportunamente expuesta por PAREJO ALFONSO ${ }^{223}$, pues simboliza la tesis de la irreversibilidad de lo que ya ha sido hallado o descubierto por el legislador como contenido del Estado social, "hallazgo" que queda petrificado por la propia fuerza de la Constitución y resistente frente a futuras medidas regresivas. La tesis, seguida por BÖCKENFÖRDE ${ }^{224}$, cuenta en España con algunos $\operatorname{adeptos}^{225}$.

La cuestión, evidentemente ligada a la ideología y proclive a la especulación, puede ser reducida, a nuestro juicio, a términos más concretos con el apoyo de la propia Constitución: ésta no contiene -tampoco los Estatutosningún precepto que establezca la irreversibilidad, sino que remite, en relación con los principios a "lo que dispongan las leyes que los desarrollen" (art. 53.3), sin que a nuestro juicio pueda entenderse comprendida en la cláusula del Estado social una figura tan drástica e intensa como la del "no retorno". Cierto que la regla de partida no puede ser otra que la del avance, pero ello no excluye la posibilidad del retroceso si concurre una razón poderosa que haga materialmente imposible el mantenimiento de lo conseguido hasta entonces. Nemo dat quod non habet, ésta es una cláusula implícita del sistema, basada en la naturaleza de las cosas y, por tanto, excluyente de cualquier otra con la que resulte incompatible ${ }^{226}$. Desde luego, siempre habrá que dejar a salvo del

${ }^{223}$ Estado social y Administración Pública. Los postulados...”, cit. pág. 54.

224 Escritos sobre derechos fundamentales, Verlagsgesellschaft, Baden Baden, 1993, pág. 81. (Traduc. J. L. Requejo e I. Villaverde).

225 DE ESTEBAN, J. y LÓPEZ GUERRA, L., El régimen constitucional español, Vol. I, Barcelona, 1984 pág. 346-347; PRIETO SANCHÍS, L., "Los derechos sociales y el principio de igualdad...", cit. pág. 39. Puede verse una indicación de posiciones favorables y contrarias a la irreversibilidad en la obra de GONZÁLEZ MORENO, B., El Estado social, cit. pág. 158.

226 Con toda razón señala MUÑOZ MACHADO que "es absurdo pretender vincular jurídicamente al Estado a mantener una prestación que la crisis económica no le permite”, remitiéndose 
posible retorno las garantías institucionales reconocidas por la Constitución, tal como el sistema público de Seguridad Social con su conjunto de prestaciones, al menos mínimo, como exige la STC 37/1994, de 10 de febrero ${ }^{227}$.

La tesis de la irreversibilidad, quizás defendible en épocas de bonanza económica es insostenible en situaciones de crisis, como certeramente ha señalado PAREJO ALFONSO ${ }^{228}$. Y para estas situaciones resulta preferible, más que la defensa a ultranza de lo imposible, la aceptación del retroceso, pero siempre en la parte en que éste sea irremediable. Salvo que el Estado caiga en una absoluta bancarrota, no será verosímil que cualquier situación de crisis legitime a los poderes públicos para desmantelar todo lo realizado en el campo de la acción social y por ello la alternativa no es otra que la de optar selectivamente, establecer prioridades en un contexto de recursos escasos ${ }^{229}$. En este sentido, se señala la conveniencia de la reversibilidad, precisamente para asegurar la preservación del núcleo esencial de las prestaciones para que éstas se proyecten hacia el mayor número de destinatarios posibles ${ }^{230}$.

Desde esta perspectiva realista, PAREJO ALFONSO señala como factible la transformación del statu quo por una política socio-económica distinta aun-

en este sentido a la jurisprudencia establecida por el Tribunal Supremo norteamericano sobre los Welfare Rights, "La crisis del Estado del Bienestar y la cuestión de la reversibilidad..." en La integración social de los minusválidos...”, cit., pág. 29. GARCíA MACHO, R. trata esta cuestión bajo el expresivo rótulo "Límites económicos de los derechos fundamentales sociales", en Las aporías de los derechos..., cit., pág. 143. En la misma línea Marc CARRILLO advierte que "en general los Tribunales Constitucionales han negado la congelación de los derechos sociales y han legitimado al legislador para que module el alcance y los límites del Estado del bienestar", "La eficacia de los derechos sociales...", cit., pág. 71.

227 GARCÉS SANAGUSTÍN, A. considera también protegida por una garantía institucional la Acción Social, concretamente el derecho al mantenimiento de un mínimo vital en cuanto ligado a la dignidad de la persona, lo que a nuestro juicio resulta discutible, por difuso. Vid. Prestaciones sociales... cit., pág. 180.

${ }^{228}$ Estado social y Administración Pública. Los postulados...cit. pág. 54.

${ }^{229}$ A este efecto MUÑOZ MACHADO propone la distinción entre prestaciones universales y las prestaciones destinadas a atender necesidades específicas de colectivos concretos; y la distinción entre necesidades que los ciudadanos podrían cubrir por sí mismos y aquellas que precisan de un soporte público para cobrar un nivel de protección razonablemente idóneo; reconoce, no obstante la dificultad de clasificar las situaciones señaladas. "La crisis del Estado de bienestar...”, cit. pág. 31.

${ }^{230}$ GOMES CANOTILHO, J. J., "Metodología ‘fuzzy'...”, cit. pág. 47. En análogo sentido PAREJO ALFONSO, Estado social...,cit. pág. 91. 
que respetuosa con los principios constitucionales de aplicación ${ }^{231}$. Por su parte, MUÑOZ MACHADO estima que no es necesaria esa sustitución por una política social diferente si las circunstancias económicas sobrevenidas imponen, lisa y llanamente, la rebaja o supresión de algunas prestaciones de carácter social y, siguiendo a K. DOHERING ${ }^{232}$, apunta como solución superadora del problema de la reversibilidad, el hecho de que el Estado tiene obligaciones derivadas de la relación de lealtad y protección con sus ciudadanos, -la de prestar ayuda social a los necesitados-, que van más allá de la fórmula del Estado social ya que estas situaciones entroncan con otros valores constitucionales, tal como el de la dignidad humana, lo que MUÑOZ MACHADO refiere al caso de los minusválidos ${ }^{233}$. Indudablemente, se trata de un postulado loable y difícilmente rechazable desde el punto de vista técnico, pero también es cierto que resultará difícil encontrar algún ámbito relevante de la acción social que no guarde claras conexiones con derechos fundamentales o valores constitucionales (la dignidad, la igualdad, el desarrollo de la personalidad, etc.). Por consiguiente, dicho criterio no logra reducir en gran medida el espectro de opciones posibles en un contexto de penuria de medios, lo que "devuelve" al legislador su originaria discrecionalidad para decidir, en un tal contexto económico, cuáles sean las líneas de la acción social a mantener y cuáles hayan de ser rebajadas o suprimidas, lo que en definitiva supone la evasión del corsé que toda regla implica. Ahora bien, a efecto de controlar la discrecionalidad del legislador siempre será un dato valioso la vinculación que guarde la prestación social en cuestión con un valor constitucional, pues claro es que no todas las acciones sociales tienen la misma trascendencia llegado que fuere el infeliz momento de recortar el gasto social en los Presupuestos.

231 Ídem, pág. 90. En cambio, considera PAREJO que sería inconstitucional cualquier política legislativa que tuviera por objeto global la reducción o la supresión por sí misma de los derechos de contenido social ya reconocidos por el ordenamiento. Ídem pág. 89, sin añadir matización alguna para el caso de una eventual y profunda crisis económica.

232 "Estado social, Estado de Derecho y Orden democrático" en El Estado Social, (con ABENDROTH y FORSTHOFF), cit., pág. 159. DOHERING precisa que la obligación evidente [sic] del Estado de prestar ayuda social a los necesitados no se deduce, o al menos no exclusivamente, del concepto de Estado social e incluso puede caber la duda de si es necesaria una tal remisión especial de la Constitución. Ello resulta del propio concepto de la pertenencia del individuo a su Estado.

233 "La crisis del Estado del bienestar..." cit. págs. 30 y ss. 
Como conclusión a cuanto precede nos atrevemos a proponer criterios -quizás no suficientes pero sí necesarios- que habrían de ser tenidos en cuenta en cualquier circunstancia:

a) en primer lugar hay que excluir la aplicación de fórmulas estereotipadas o supuestas "reglas de oro 234 ", puesto que la Constitución no las contiene ni la jurisprudencia las ofrece. En puridad, sólo cabría una regla y es la de que, en principio, la tendencia deber ser la de avanzar y no retroceder ${ }^{235}$, regla ésta que aunque nace vocada a ceder y a acomodarse a las circunstancias, señaladamente en el caso de la regresión de los niveles prestacionales ya conseguidos, debe considerarse como la regla-guía permanente e irrompible, la única posible con la Constitución en la mano. Todo lo demás serán excepciones consentibles, en su caso, dada la flexibilidad que es propia de la categoría jurídica de que se trata.

b) un segundo criterio recomendable es el de no fijarse en exceso en las soluciones adoptadas por órganos judiciales de otras latitudes, dados los riesgos consabidos, especialmente si se fundan en criterios economicistas que, aunque razonables, no tienen encaje en nuestro ordenamiento jurídico.

c) es obligado reconocer un amplio margen de discrecionalidad de los poderes públicos en ese complejo mundo de la ejecución de

\footnotetext{
234 Valga citar, por ejemplo, la regla que propone PRIETO SANCHÍS, L., según la cual los derechos prestacionales no imponen una obligación de avanzar y sí una prohibición de retroceder, "Los derechos sociales y el principio..." en Rev. del Centro de Estudios..., cit. La regla en cuestión entronca claramente con la opinión sostenida por LÓPEZ GUERRA, L., sobre la irreversibilidad de los derechos sociales a la que aludimos supra, formulada así: "los principios rectores de la política social y económica aparecen así como una garantía del 'mínimo existente', en el sentido de que el statu quo socioeconómico, si se modifica, ha de serlo en la dirección indicada por la Constitución. Desde esta perspectiva, la Constitución trata, pues, más que de forzar un avance, de evitar un retroceso en la realización del Estado social”, ob. cit. pág. 346-347.

235 Como señalan ABRAMOVICH, V. y COURTIS, Ch., la obligación de progresividad y prohibición de regresividad es la regla de partida del artículo 2.1 del Pacto Internacional de los Derechos Económicos, Sociales y Culturales, "Los derechos sociales como derechos exigibles", cit. pág. 93. CARRETERO SÁNCHEZ, S., se adscribe a esta línea señalando atinadamente que ello genera la presunción de ilegitimidad de la medida regresiva desplazando al Estado la carga de probar la existencia de una justificación racional e imperiosa. El cambio de los derechos sociales y su justiciabilidad. Impacto jurídico de la inmigración en la teoría tradicional de los derechos humanos, cit., págs. 141-143.
} 
los principios rectores, reservando el llamado "activismo judicial" sólo para las situaciones manifiestamente arbitrarias o claramente contrarias a la letra o al sentido mismo del principio rector.

d) será fundamental en todo caso constatar si los órganos responsables del desarrollo de los principios rectores actuaron -o dejaron de actuar- legitimados por una justificación razonable susceptible de comprobación, capaz de disipar la duda de que se hubiese obrado en fraude de ley, en este caso, estatutaria. Existen sobre este punto aportaciones doctrinales muy aquilatadas ${ }^{236}$.

e) como contrapunto de los criterios anteriores será necesario también que los órganos jurisdiccionales extraigan del ordenamiento jurídico y señaladamente de las leyes procesales las interpretaciones necesarias con el fin de impedir que ante una situación de flagrante incumplimiento del Estatuto el sistema jurídico se quede en punto muerto, inerme, incapaz de reacción, ya que esto supondría el fracaso del sistema al asumir éste la impunidad ante el incumplimiento de mandatos legales. El Derecho debe tener previstos los mecanismos para dar respuesta adecuada a estas "disfunciones" si convenimos en que lo que se manejan son normas y que por ello no puede quedar la cuestión confiada sólo a los controles políticos.

Hay que insistir en que todo cuanto precede sólo es referible a los "derechos" sociales en sentido amplio u objetivo, esto es, a los contenidos en los principios rectores, sean constitucionales o estatutarios; o dicho de otra forma, a un espacio de situaciones jurídicas inestables, distinto del mundo de los auténticos derechos y, por tanto, muy a merced de la economía y la política y sus inherentes amplios márgenes de alternancia y maniobra. Obviamente, muy poco o nada de lo dicho hasta aquí sería predicable de los derechos so-

\footnotetext{
${ }^{236}$ Son muy destacables las propuestas de ABRAMOVICH, V. y COURTIS, Ch. Así, sobre este punto señalan que las restricciones a los derechos sociales no han de ser arbitrarias, sino razonables; que se encuentren justificadas por los hechos o circunstancias sociales que le han dado origen y por los fines lícitos perseguidos por la norma; que exista una adecuada proporcionalidad entre las restricciones y los antecedentes y fines de la medida. Además, queda desplazada al Estado la carga de demostrar la estricta necesidad de la medida, lo que le exigirá probar: a) la existencia de un interés estatal permisible; b) el carácter imperioso de la medida, c) la inexistencia de cursos de acción alternativos menos restrictivos del derecho en cuestión. Los derechos sociales como derechos exigibles, cit. págs. 100 y ss.
} 
ciales configurados como verdaderos derechos subjetivos pues éstos quedan a resguardo de las fluctuaciones a las que eventualmente sí están sujetos los principios, al menos en lo que concierne al núcleo irreductible de las prestaciones garantizadas ${ }^{237}$.

Refiriéndonos ya a los genuinos derechos hay que notar que la Constitución sólo ha consagrado como derechos subjetivos -fundamentales- un escaso número de "derechos sociales", reduciendo así al mínimo el alto compromiso que muchos de ellos representan para las arcas públicas, señaladamente el derecho a la educación, ex art. $27 \mathrm{CE}$. En lo demás, el legislador queda constitucionalmente vinculado en cuanto a la orientación a seguir mas no en cuanto a la fórmula a aplicar. Pero si éste, en uso de su poder político, opta por materializar su acción social con la vitola del derecho subjetivo judicialmente exigible (lo que presuntamente le hará ganar prestigio y puntos de cara al electorado) tendrá que arrostrar las consecuencias de haberse autovinculado tan estrechamente, o sea, de haber creado una situación que aunque no sea absolutamente irreversible en teoría ${ }^{238}$ sí lo será probablemente en el plano fáctico, dada la imponente carga que representa el tener que responder ante la miríada de posiciones individuales consolidadas por cualquier alteración sustancial de su statu quo. Ello aparte la dificultad de orden político y social que conlleva el incidir desfavorablemente en el campo de los iura quaesita.

En suma, la existencia de una prestación social cubierta con la veste del derecho subjetivo hará quebrar cuanto queda dicho sobre los fenómenos de la desviación, la inactividad y el retroceso en la ejecución de los principios rectores. En efecto, definido que fuere por la norma el derecho subjetivo no será admisible el más mínimo desvío por el desarrollo normativo ulterior y la actuación administrativa, debiendo reputarse inválido todo lo que no con-duzca a

\footnotetext{
${ }^{237}$ Son imprescindibles al respecto las reflexiones de MUÑOZ MACHADO, S., en La formación y la crisis de los servicios sanitarios públicos, Alianza Editorial, Madrid, 1995, págs. 150 y ss.

238 Contrariamente, MUÑOZ MACHADO apunta a la posibilidad de que el legislador, al haber concretado el derecho, quede autovinculado por el contenido de su propia norma, obligado a ello por la cláusula del Estado social de la Constitución. "La crisis del Estado del bienestar y la cuestión de la reversibilidad...", cit. pág. 28. A nuestro juicio, en todo caso habrá que entender implícito que la fuerza de la cláusula referida no puede llegar a paralizar el poder del legislador si éste cuenta con una justificación razonable que le haga cambiar de parecer, dicta el pertinente contrarius actus y, desde luego, respeta los derechos ya adquiridos o resarce debidamente a los perjudicados con las compensaciones a que tuvieran derecho.
} 
cumplir derechamente el mandato legal; y tan condenables como lo anterior deben considerarse las conductas omisivas que bloqueen lo que el legislador ha querido que se haga sin dilación alguna. Y por igual o mayor razón queda excluida en esta sede toda posibilidad de especular sobre la reversibilidad de lo reconocido y otorgado con el carácter de derecho subjetivo.

En fin, por más que desde la Economía o la Política se eludan estos matices a la hora de pronunciarse sobre la suerte de la acción social en una situación económica adversa como la que vivimos, el Derecho tiene que hacer relucir el valor de sus reglas de siempre y con ellas hacer ver que no todas las situaciones son claudicantes por igual y que los poderes públicos, generalmente excedidos en sus promesas, no lo tienen tan fácil a la hora de recoger velas y buscar soluciones ligeras para los derechos sociales. Es precisamente en momentos de crisis cuando resurge la fuerza aleccionadora del Derecho y se hace patente la necesidad de obrar prudentemente tanto a la hora de formular promesas y derechos en tiempos de bonanza como a la del repliegue en momentos difíciles. No cabe huir en desbandada como si el Derecho no existiera. Hay un regla jurídica sencilla que debe saberse como la escribiera OTTO MAYER hace ya más de un siglo al referirse a los derechos públicos subjetivos: "es cosa bastante seria la de crear semejantes relaciones jurídicas. Que la ley puede hacerlo, no cabe duda. Pero... tan pronto haya sido creado sin reservas un poder del individuo sobre la potestad pública, habrá derecho público individual subjetivo y, por consiguiente, relación jurídica irrevocable ${ }^{239}$ ". Pero esto, que es válido para las leyes en general, no lo es para los Estatutos de Autonomía según hemos visto, a no ser que el TC cambie de opinión en fecha próxima.

Sevilla, diciembre 2008

\footnotetext{
239 Derecho Administrativo Alemán, tomo I, Edit. De Palma, Buenos Aires, 1949, págs. 154 y 155 (trad.del original francés Le droit Administratif Allemand, París, 1903). Sobre tal irrevocabilidad, valga la consideración dicha en la nota anterior.
} 